\title{
APERTURA DEL ISTMO DE OFQUI: HISTORIA DE UNA QUIMERA. CONSIDERACIONES SOBRE LA VIGENCIA DE SUS RAZONES
}

MATEO MARTINIC B.

\section{RESUMEN}

A comienzos del siglo XX se planteó la posibilidad de construir un canal a través del istmo de Ofqui (península de Taitao) para abrir una ruta de navegación más segura y más corta para vincular mejor a Magallanes con el territorio metropolitano de Chile, como propuesta de variado beneficio económico, social y político. Controvertida desde un comienzo la iniciativa, el gobierno del Presidente Arturo Alessandri decidió llevar adelante su construcción en 1935. Las obras se iniciaron a fines de 1937 y se suspendieron definitivamente en mayo de 1943. El artículo da cuenta pormenorizada del origen y la evolución de este proyecto, de sus implicaciones variadas en distintos respectos y analiza las razones actuales para la integración intrarregional patagónica chilena.

PALABRAS CLAVE: Patagonia occidental, istmo de Ofqui, comunicaciones marítimas, integración territorial.

\section{STORY OF AN ILLUSION: THE OPENING OF OFQUI ISTHMUS. THE CONTINUING VALIDITY OF THEIR REASONS}

\begin{abstract}
In the early XX century the possibility of building a canal across the Isthmus of Ofqui (Taitao peninsula), to open a safer and shorter navigation route to better link from Magallanes with the metropolitan territory of Chile, was proposed. The proposal was raised for varied economic, social and political benefits. Controversial from its beginning, the initiative was brought forward by the government of President Arturo Alessandri that decided its construction in 1935. Work began in late 1937's and finally ended in May 1943. This article gives a detailed report on the origin and evolution of this project, its varied implications in different respects and analyzes current reasoning for Chilean Patagonia intraregional integration.
\end{abstract}

KEY WORDS: Western Patagonia, Ofqui isthmus, maritime communications, territorial integration.

\footnotetext{
* Profesor Emérito, Centro de Estudios del Hombre Austral, Instituto de la Patagonia, Universidad de Magallanes, Chile. mateo.martinic@umag.cl.
} 


\section{INTRODUCCIÓN}

El aislamiento geográfico magallánico y por consiguiente la necesidad de superarlo mediante comunicaciones eficaces ha sido una circunstancia motivante que históricamente se dio, en especial entre la segunda mitad del siglo XIX y la segunda del XX, en doble sentido. De una parte, del centro metropolitano -el Gobierno y la administración nacionales- hacia la periferia austral y de la otra, desde el territorio magallánico, en particular desde su centro capital Punta Arenas, en ambos casos en procura de una cada vez mayor y mejor vinculación teniendo en vista los intereses superiores de la $\mathrm{Na}$ ción (la soberanía sobre el ámbito meridional) y los propios del fenómeno progresivo del poblamiento civilizado y del consiguiente desarrollo económico (comunicaciones expeditas, frecuentes y suficientes).

Tal circunstancia exigía desde un principio necesariamente superar en cuanto se pudiera las formidables dificultades que oponían las características naturales del territorio patagónico occidental que por entonces y dado el elevado grado de desconocimiento que se tenía sobre el mismo por la clase dirigente del país - en el convencimiento de que cualquier alternativa viable o posible debía darse por suelo chileno- no dejaba más opción que la vía marítima, considerada en su empleo más seguro y eficiente para la navegación. Esta, en general preveía el uso del océano Pacífico hasta la latitud del canal de Chacao (pensando en Valparaíso y otros puertos de la zona metropolitana centro-sur como Talcahuano y Corral) y desde allí hacia el sur y viceversa el sistema del golfo de Corcovado y canales patagónicos septentrionales, otra vez el Pacífico para acceder al golfo de Penas y traspuesto este, el de los canales patagónicos meridionales y estrecho de Magallanes para unir a los puertos intermedios (Puerto Montt, Ancud, Castro) con Punta Arenas.

Pero en ese extenso tracto de mil millas el golfo de Penas conformaba por sus conocidas características de espacio marítimo abierto a las influencias oceánicas, el sector más riesgoso cuya navegación exigía el mayor cuidado de capitanes y pilotos de los barcos que debían seguirlo con sentido norte-sur y viceversa. Ello, naturalmente sin dejar de lado el progresivo mejor conocimiento de la hidrografía de la extensa ruta, materia en la que se estaba, casi sin pausa, desde los años de 1830 que cerraron el ciclo exploratorio emprendido por el Almirantazgo Británico a contar de 1826, en procura de la seguridad de la navegación y del comercio entre Europa y Sudamérica que en buena parte debía realizarse por la vía marítima franca como es el estrecho de Magallanes en el extremo meridional de América. Esta tarea había sido responsablemente asumida por la Armada de Chile a contar de los años de 1870, entendida como una empresa laboriosa sin fecha de término.

De pronto, al tiempo de cambio de los siglos XIX al XX, el mayor conocimiento que permitió acumular aquella faena técnica y científica en lo referido a la sección centro patagónico occidental y en particular las exploraciones realizadas en la parte marítimo-continental de todo el territorio de la Patagonia situado en general entre los fiordos de Reloncaví y de Última Esperanza, hizo posible reactualizar las antiguas nociones de los aborígenes canoeros referidas a los pasos más convenientes y seguros de navegación e intercomunicación de los sectores litorales.

Entre estos estaba la extensa vía conformada por el fiordo Elefantes que separa en dos partes la tierra firme patagónica entre aproximadamente los $46^{\circ} 40^{\prime}$ y los $47^{\circ} 20^{\prime} \mathrm{S}$, generando hacia el oeste la gran península de Taitao unida al mayor sector continental del este por el istmo de Ofqui. Este paso conocido desde tiempo inmemorial por los indígenas chonos y posiblemente también por los kawéskar y utilizado en consecuencia para sus desplazamientos nomádicos, incluyendo el arrastre de sus embarcaciones, práctica que a partir del siglo XVII retomaron los religiosos jesuitas y franciscanos en sus viajes misionales hasta fines del siglo XVIII, fue objeto de una primera exploración científica con el viajes del comandante Enrique Simpson, de la Armada de Chile, en 1873, proseguido con los trabajos hidrográficos a cargo de los capitanes Guillermo García Huidobro y Baldomero Pacheco en los primeros años de la década de 1900 y por las exploraciones realizadas por el geógrafo Hans Steffen en 1899 en zonas continentales aledañas. Precisamente tras la comisión de García Huidobro con la corbeta Pilcomayo, fue que se planteó la posibilidad de la apertura del istmo para generar una vía alternativa de navegación entre Puerto Montt y Punta Arenas.

La idea una vez conocida despertó interés en 
el Gobierno y en otros ambientes y fue asumiendo paulatinamente las proporciones de un proyecto, despertando de paso ilusiones entre la población magallánica a la que se vio desde un principio como la gran beneficiaria del mismo. Sin embargo las obras correspondientes no pasaron de la etapa inicial y la propuesta devendría al fin una utopía. Cabe, pues, dar a conocer, para la historia, lo que fueron sus avatares y repasar sus motivaciones en la perspectiva de encontrar en el mantenimiento de la principal de ellas -la integración territorial patagónica (Aysén, Magallanes) al cuerpo metropolitano de la República- una razón suficiente para fundar mejor este trascendente imperativo nacional todavía pendiente.

\section{EL ISTMO DE OFQUI}

Entre los $45^{\circ} 50^{\prime}$ y $47^{\circ}$ de latitud sur la tierra continental patagónica alcanza

hasta el borde del océano Pacífico en la forma de una vasta península que está en buena parte separada de aquélla por la secuencia de aguas interiores conformada de norte a sur por el fiordo Elefantes, el golfo de San Esteban y la laguna de San Rafael. Entre esta última y la bahía de San Quintín al sur se ubica un istmo que la une al continente cuya angostura menor, medida entre costas marinas es de veinte kilómetros. Pero, observada esta circunstancia con cuidado en un mapa a escala intermedia (p. ej. 1:300.000 como es el caso de la carta N 813 "Bahía Anna Pink a Canal Messier" S.H.O.A.), se advierte que la zona ístmica de tierra emergida se reduce notoriamente hasta un décimo de la anchura dada, por la existencia de cursos de agua permanentes que la cortan en general con sentido NNE/SSO: ríos Negro, Lucac, San Tadeo y Paso Expedición que sólo dejan entre la cabecera del primero y la orilla sur de la laguna San Rafael una angosta lonja de tierra de unos dos kilómetros de tierra baja -el istmo propiamente tal- como lo es en general toda el área, debido a la dinámica geomorfológica propia del sector que da cuenta de hundimientos por razones telúricas (sísmicas), característica históricamente atestiguada por los restos de bosques sumergidos.

Esta circunstancia geográfica fue conocida tempranamente, desde tiempo inmemorial, por los pueblos indígenas canoeros que desde a lo menos cinco o seis milenios antes del presente pasaron a ocupar los vastos espacios marítimos y litorales del laberinto norpatagónico occidental que conformaron sus territorios ancestrales. Así, con el profundo dominio que llegaron a tener de su geografía marítima supieron utilizar todos los istmos franqueables a pie en sus rutas de navegación por las aguas interiores de la Patagonia occidental. Aprovecharon aquéllos de tal modo las tierras llanas litorales, con humedales y pantanos que las rellenaban o con ríos que las cortaban para trasladarse de un punto a otro en sus desplazamientos nomádicos, llevando a cuestas desarmadas, cuando así era necesario, sus sencillas pero eficientes embarcaciones de tablas, las bien afamadas dalcas, conocidas y descritas por los españoles a contar de mediados del siglo XVI.

Establecida a firme la presencia de los conquistadores hispanos con la fundación del puesto poblado avanzado de Castro (1567), los mismos no tardaron en relacionarse con los habitantes indígenas de su entorno, en especial hacia el sur, que gracias al auxilio de los mismos como inestimables e insuperables guías les permitió conocer su compleja geografía marítima circundante y aprovechar el valioso legado de sus tradiciones vernáculas. El paso intermedio, sin duda alguna el más importante por cuanto permite la comunicación entre dos ambientes diferentes naturalmente, se denominaba Ofqui, voz indígena posiblemente de origen chono y de significado desconocido, al que los españoles redenominaron Desecho (o del Desecho). Se estableció y mantuvo de tal manera a lo largo de dos siglos y medio una preocupación jurisdiccional laxa pero no por ello menos determinante para la continuidad de la noción de pertenencia soberana, que la historiadora María Ximena Urbina ha descrito certeramente como "frontera móvil" del imperio español y en específico del Reino de Chile, a través de su provincia de Chiloé, sobre el ámbito patagónico occidental pacífico ${ }^{1}$.

Pero esa tradición y conocimiento se fueron

1 Para una debida información sobre la materia recomendamos la lectura de los excelentes artículos de esta autora que la tratan en profundidad: La navegación por los canales australes de la Patagonia occidental en los siglos coloniales: la ruta del istmo de Ofqui en Magallania 38(2):41-67) y Expediciones a las costas de la Patagonia occidental en el período colonial (en este mismo volumen );y también nuestra Historia de la Región Magallánica tomo I (1992 y reedición 2006) y de la Trapananda al Áysen (Pehuén Editores, Santiago 2005). 
olvidando según adelantó el siglo XIX en tanto que en su transcurso se extinguieron los últimos representantes de la etnia chona y recién revivirían para la ciencia geográfica a contar de las exploraciones del capitán Enrique Simpson de la Armada de Chile (1873). Esa laguna, sin duda, es la verdadera de San Rafael de los jesuitas del siglo pasado, relataría Simpson al informar sobre su redescubrimiento, pero se había perdido tanto de vista que ni el práctico don Juan Yates, que es el ser viviente más antiguo de estas regiones, tenía idea de su existencia. Los indios Chonos la dieron a conocer a los reverendos padres, y aún existen tradiciones como que algunos de estos misioneros, acompañados de los indios, cruzaron el istmo de Ofqui, arrastrando sus piraguas, las cuales volvieron a lanzar en un río al otro lado, y de este modo llegaron hasta el golfo de Penas ${ }^{2}$.

Entre tanto, en especial a contar de los años de 1820 el tráfico ocasional de foqueros y loberos por el ámbito litoral sudoccidental de América y en especial los trabajos hidrográficos practicados por la Armada Real Británica entre 1826 y 1834 permitieron ampliar el conocimiento de la geografía marítima y poner en uso rutas de navegación en los sectores archipielágicos situados al norte y al sur del golfo de Penas hasta el estrecho de Magallanes.

Perdida esa tradición por causa del despoblamiento de los archipiélagos de las Guaitecas y los Chonos debido a traslados forzosos de aborígenes durante los siglos XVII y XVIII, el remanente de habitantes reducido numéricamente por diferentes razones se concentró en los sectores históricamente poblados de Chiloé (isla grande y algunas menores contiguas en el mar interior de Corcovado) y allí se mantuvo en un estado de ínfimo desarrollo si no de virtual letargo ceñido a sus pautas tradicionales de autosubsistencia a través del aprovechamiento de sus recursos naturales ${ }^{3}$.

Fue precisamente esta circunstancia económica la que hizo posible la paulatina expansión colonizadora hacia el litoral continental norpatagónico y hacia las islas Guaitecas y de los Chonos, de la mano de

2 Viajes de exploración por los archipiélagos australes (Ofqui Editores, Temuco 2011), pág. 65.

3 Para comienzos del siglo XIX se ha registrado una población total para Chiloé de 36.232 individuos, cantidad que pasada la mitad de la centuria, en 1859 , solo había aumentado a 39.886 habitantes, lo que grafica su escaso crecimiento. los "tableros" (explotadores del alerce) en el primer caso y de los cipreceros (explotadores del ciprés) y de los cazadores de nutrias y lobos marinos en el segundo. Estas actividades que tenían precedentes en los comienzos del siglo y aún en las postrimerías del anterior que cobraron importancia pasada la mitad de la centuria, hacia 1860, conformaron una expansión colonizadora sui generis por cuanto no tuvieron como consecuencia el establecimiento de poblaciones permanentes, con la excepción de Melinka en las islas Guaitecas, pues más bien se trató de un fenómeno de ida y vuelta de largo curso temporal que animó un creciente movimiento de pequeñas embarcaciones veleras para el transporte de personas y cargas. De esa manera al concluir el siglo el área norte de la Patagonia occidental, Chiloé y sus islas incluidos, era un ámbito geográfico bastante conocido en sus sectores litorales, teatro de un movimiento marítimo autónomo extendido hasta sectores continentales como Calbuco y Puerto Montt que acabarían dominándolo.

Traspuestos la península de Taitao y el golfo de Penas se hallaba la antigua Magallania (su parte archipielágica occidental), zona de viajes misionales y jurisdiccionales ocasionales durante el tiempo colonial que había pasado a ser mejor conocida tras las exploraciones de la Marina Británica de 18261830 y de las incursiones ocasionales de foqueros norteamericanos e ingleses contemporáneos. Fue así que aprovechando ese conocimiento, no obstante que todavía en mucho perfectible, pudo realizarse exitosamente en 1843 la expedición de la goleta Ancud comandada por Juan Williams y salida del puerto homónimo, dispuesta por el gobierno del Presidente Manuel Bulnes -inspirada por el pensamiento visionario del Libertador Bernardo O`Higgins- para hacer efectiva la ocupación del estrecho de Magallanes y sus territorios (Patagonia austral y Tierra del Fuego). Establecida la primera población en la punta de Santa Ana, la misma fue trasladada en 1848 a un lugar más habitable como era Punta Arenas, fundación que pasó por varios avatares de signo adverso evolucionando de presidio militar a colonia en forma hacia 1868-1870, situación coyuntural que permitió la mutación del establecimiento en plan de adelanto, gracias a la inmigración libre, al desarrollo de la navegación comercial entre Europa y Sudamérica por la vía del estrecho de Magallanes y a la explotación inicial de 
algunos recursos naturales, en especial de las pasturas de la sección esteparia oriental del territorio, lo que permitió la exitosa implantación de la ganadería ovejera extensiva a contar de 1876-1880.

Sobre este auspicioso carril económico la Colonia de Magallanes fue creciendo y afirmándose, extendiendo la ocupación colonizadora por todo lo ancho de la zona situada en la vertiente andina oriental, aumentando la población y la producción económica con creciente autonomía y en íntima relación con Europa, continente que la proveía de inmigrantes y de bienes de toda clase y que era el destino de sus productos en especial del más importante, la lana.

En este contexto de autonomía relativa de funcionamiento la vinculación de Magallanes con Chile metropolitano se había mantenido de modo regular a contar de 1868-1870 con la operación de los servicios de navegación de ultramar (Europa, costas orientales de Norte y Sudamérica), que recalaban en Punta Arenas como puerto de itinerario en los viajes hacia y desde las costas de Chile central y Perú hasta Panamá. Chiloé (puertos de Ancud y Castro) y Puerto Montt y sus respectivas áreas de influencia de algún modo aprovecharon esas líneas de navegación regular para establecer una relación con Punta Arenas. Esta, inicialmente de carácter menor, pasó a ser más intensa hacia el fin del siglo XIX cuando el proceso dinámico de progresista desarrollo de Magallanes sirvió de estímulo para la emigración de la población laboral disponible en Chiloé por razón de su estancamiento económico e inclusive para el inicio de un limitado comercio de intercambio, principalmente de alimentos originarios del campo y mar chiloenses.

En ese fenómeno de articulación geográficomarítima entre el norte de la Patagonia occidental y la extensa región de Magallanes en el lejano sur durante el período de cambio de siglos del XIX al $\mathrm{XX}$, la reutilización de la antigua vía marítima de intercomunicación conformada por los canales patagónicos, istmo de Ofqui de por medio, vino a ofrecerse como una posibilidad que valía considerar de cara al porvenir.

Para entonces, por otra parte, comenzaban a despertar interés las zonas interiores del territorio continental patagónico norcentral debido a la vigencia de la disputa por su dominio entre Chile y la República Argentina, por razón de la doble interpretación dada al deslinde internacional en la zona andina pactado por el Tratado de 1881 y que tuvo una solución satisfactoria con el laudo arbitral pronunciado a fines de 1902 por el rey Eduardo VII de Gran Bretaña. De ese modo las áreas asignadas definitivamente a Chile pasaron a ser objeto de interés público y privado para su colonización, proceso que se iniciaría efectivamente a contar de 1903 con la entrega de las primeras concesiones de terrenos en arrendamiento a compañías creadas expresamente para tal objeto, que abarcaban amplios espacios territoriales que corrían desde el litoral continental interior hasta la frontera internacional, cuyos correspondientes sectores de penetración hacia el oriente, tierra adentro, en donde se creía o se sabía que se encontraban los campos más aptos para la explotación pastoril, se situaron en las principales desembocaduras fluviales de dicho litoral desde el fiordo del Baker por el sur hasta el de Comau por el norte. También en este caso particular la posibilidad de un canal a través del istmo de Ofqui podía, eventualmente, jugar un papel interesante en la vinculación intrarregional del nuevo territorio que con el nombre de Áysen se incorporaba a la vida y a la economía nacionales.

Bien considerada la situación, a la vista del superior interés nacional, todo aconsejaba entonces como cosa necesaria y buena la integración cada vez más real y efectiva de los nuevos territorios como eran Magallanes y el Áysen, y el más antiguo de Chiloé, tanto entre sí como con el cuerpo metropolitano del país, Era un desafío formidable, como quiera que se lo considerara, el de integrar territorios en la forma planteada -el uso más eficiente de las rutas marinas interiores-, habida cuenta de su magnitud areal (1/3 del territorio nacional), de las dificultades colosales impuestas por la geografía y el clima, de su infradesarrollo económico y su bajísimo poblamiento, Ciertamente aquella era una tarea de largo, larguísimo aliento, mucha preocupación y recursos cuantiosos. Pero el interés superior de Chile así lo exigía entonces y lo exigiría más en el porvenir.

\section{PROYECTO DE APERTURA DEL ISTMO DE OFQUI}

\section{Origen de la iniciativa}

Los antecedentes que han podido compulsarse acerca de la posibilidad de apertura de un canal 
de navegación en el istmo de Ofqui permiten situar el surgimiento de las primeras ideas en tal respecto en la época del establecimiento soberano de Chile en las tierras del estrecho de Magallanes, con más precisión hacia 1844 cuando se advirtió la necesidad de apoyar tal medida mediante las comunicaciones marítimas, inicialmente entre el recién fundado Fuerte Bulnes y Chiloé y posteriormente Valparaíso. Podría conjeturarse que tras tal pensamiento estuvieran marinos con cierta experiencia en la navegación del laberinto patagónico como era el capitán Juan Williams y el piloto Jorge Mabon. La idea fue retomada años después, en 1852, por el Gobernador de la Colonia de Magallanes Bernardo Philippi que había integrado la expedición de la goleta Ancud en 1843, quien reiteró al gobierno del Presidente Manuel Montt la necesidad de asegurar la comunicación marítima entre Chile metropolitano y la remota Colonia como una garantía para su permanencia.

Si por entonces nada ocurrió y el asunto pareció olvidado por casi medio siglo, es claro que la iniciativa se reactualizó en las postrimerías del siglo XIX en el ambiente de la oficialidad de la Armada de Chile, motivada en la situación de tensión que por la época se daba entre Chile y Argentina a propósito de la controversia todavía no resuelta sobre el trazado de límites en las zonas cordillerana y precordillerana oriental de la Patagonia entre los grados $41^{\circ}$ y $52^{\circ}$. En efecto, sin embargo de hallarse el asunto sometido al arbitraje de la Corona Británica por acuerdo pactado en 1898, se sucedieron en el lapso que faltaba del siglo y en los comienzos del siguiente una serie de incidentes que por momentos extremaron la tensión entre los dos países al punto de temerse el estallido de la guerra.

Tan cierto fue así que muchos años después el antiguo oficial naval y prestigiado explorador patagónico Ramón Serrano Montaner recordaría haber sido visitado, ya en retiro, por su amigo el almirante Simpson, a la sazón miembro integrante del Consejo Naval, quien lo haría [...] con la misión de pedirme que aceptase el cargo de la defensa del Estrecho, como jefe superior civil y militar, con las plenas atribuciones de un general en campaña al frente el enemigo, proposición que, felizmente la tempestad internacional [situación de tensión con la República Argentina] amainó; pero quedó impuesto de la situación y sus dificultades. Supe que el Consejo Naval había acordado dejar a la Escuadra en libertad para operar dentro o fuera del Estrecho, como creyese conveniente. Además había dispuesto aumentar todo lo posible nuestra escuadra sutil (torpederos, destróyeres, submarinos, escampavías, etc.) pero su traslación ofrecía, sin embargo, serias dificultades por la existencia del istmo de Ofqui que impedía su paso, lo que tenía muy molesto al almirante Montt, presidente del Consejo, por no haber hecho abrir ese istmo durante su gobierno, lo que habría permitido utilizar a la bahía de San Quintín como apostadero de esa escuadra sutil, dándole una fácil comunicación con el norte y una retirada segura ante una fuerza mayor, lo que habría hecho de esa bahía una posición estratégica de primer orden ${ }^{4}$. El conflicto, entonces o eventualmente en cualquier otro momento del futuro habría de tener como teatro de las operaciones navales consiguientes las aguas interiores y/u oceánicas de Magallanes y en tal supuesto la más rápida movilidad estratégica de las naves de la flota de guerra nacional cobraba gran importancia. En este respecto, si bien las unidades de línea (cruceros) entonces disponibles dado su peso que iba entre 8.500 y 3.600 toneladas debían necesariamente utilizar las aguas del Pacífico y los canales más profundos de las aguas interiores patagónico-occidentales, el resto de la fuerza de combate integrado por cazatorpederos, destructores y torpederas desplazaba hasta un máximo de 800 toneladas por unidad y por tanto sí podían utilizar los canales para su navegación. Y en este caso podía ser importante acortar y hacer más segura la ruta habitual que seguía el eje golfo Corcovadocanal Moraleda-canal Messier-canal Ancho y demás hacia el sur y viceversa como referencias principales, abriendo un canal en el istmo de Ofqui que evitara el largo rodeo de la península de Taitao y los riesgos propios de la navegación oceánica y del golfo de Penas con el añadido de la utilización de la bahía de San Quintin, situada en la parte sur del istmo, como amplio, seguro y cómodo fondeadero para toda la flota chilena, de situación intermedia, además, en la ruta Puerto Montt-Punta Arenas (Fig.1).

En tal certidumbre todavía cuatro décadas después el capitán de navío en retiro de la Armada de Chile Guillermo García Huidobro, devenido el más ardiente propagandista y defensor de la apertura del

4 Artículo publicado bajo el título "Ofqui" en el diario El Mercurio de Santiago de 10 de agosto de 1935 y reproducido por el diario El Magallanes de Punta Arenas, edición del 6 de septiembre del mismo año. 
istmo, podía reafirmar su importancia geopolítica en entrevista concedida al diario El Magallanes de Punta Arenas, señalando: la bahía de San Quintín adquiere automáticamente una importancia estratégica única en la región austral y se impone como base naval y aérea ${ }^{5}$, ya que desde Talcahuano a Magallanes ${ }^{6}$ o existe puerto alguno, por su configuración y posición geográfica en condiciones superiores a ella ${ }^{7,8}$.

\section{Trabajos hidrográficos iniciales (1905)}

En ésas y por seguro también en otras consideraciones náuticas y estratégicas hubo de fundarse la decisión adoptada por el alto mando naval (Dirección General de la Armada) en orden a disponer una doble comisión para realizar el levantamiento hidrográfico de las áreas marítimas contiguas al istmo por el norte y por el sur y que fueron encomendadas a los capitanes de fragata Guillermo García Huidobro y Baldomero Pacheco respectivamente. Estas operaciones fueron efectuadas en 1905 y deben ser tenidas para la historia como las primeras hechas en plan de adelantar en la iniciativa de la posible apertura del istmo de Ofqui con el debido conocimiento hidrográfico de las aguas que permiten acceder al mismo por el norte y por el sur.

La tarea encomendada al primero se realizó con la corbeta Pilcomayo y consistió en el relevamiento del paso Quesahuén que permite el acceso desde el fiordo Elefantes por el norte a la rada de San Rafael; el de esta bahía y del río de los Tém-

5 Téngase presente que en la década de 1930 la apertura de la ruta aérea a Magallanes, vista como objetivo de interés nacional, suponía su desarrollo por la zona de los canales patagónicos con el empleo de hidroaviones.

6 Topónimo con el que por la época había pasado denominarse a Punta Arenas.

$7 \quad$ Edición extraordinaria del 17 de noviembre de 1939.

8 García Huidobro reiteraría tal entendimiento estratégico en un artículo publicado en El Mercurio de Santiago bajo el título "Problema que requiere solución pronta y definitiva" (reproducido en El Magallanes de 3 de agosto de 1935). Lo curioso es que tal circunstancia no pasó desapercibida para la Armada Argentina - el eventual adversario de la chilena en un conflicto-, conjetura avalada por el hecho comprobado de la presencia de unidades de su flota de mar en el lugar en 1940, según información recogida por Benjamín Subercaseaux en su libro Chile o una loca geografía (pág. 232 edición de 1973) y posteriormente de otra incursión furtiva denunciada por la prensa nacional, en el caso del buque Bahía Thetis en el curso de 1955. panos que franquean la entrada a la laguna de San Rafael, y del río San Tadeo que corre en la zona del istmo. Baldomero Pacheco a su turno, al mando de la cañonera Magallanes, realizó en simultaneidad las operaciones de relevamiento en el flanco marítimo meridional del istmo definido por la bahía de San Quintín y el golfo de San Esteban que intercomunica sus aguas con las del mayor de Penas. La suma de estos levantamientos y sus trabajos complementarios desarrollados por el capitán Agustín Astudillo con el escampavía Pisagua, fueron recogidos en el plano Bahía San Quintín, Istmo de Ofqui, Laguna San Rafael, Golfo Elefantes (escala 1:200.000) publicado por el Instituto Hidrográfico de la Armada de Chile en el mismo año 1905.

Sin embargo de ser concurrentes sus objetivos, las conclusiones resultantes de ambas comisiones fueron diferentes. Así, el comandante García Huidobro apoyó decididamente la apertura de un canal a través del istmo estimándola de utilidad para la seguridad de la navegación y el ulterior fomento de la colonización de las áreas circundantes, obra que debía realizarse en lo tocante a su costo en una relación razonable con los recursos financieros del país y que en su desarrollo debía apoyarse en los factores naturales que la favorecían. Esto en lo que decía con las eventuales dificultades para la navegación que circunstancialmente podrían presentarse en el paso Quesahuén y en la laguna de San Rafael por la presencia de témpanos desprendidos del glaciar homónimo, pero por otra parte aprovechando la acción erosiva (dragado) del hielo de dicho accidente en la profundización de los fondos fluviales y lacustres, del mismo modo que los hundimientos del terreno en la zona del istmo. Para el diseño del canal, García Huidobro recomendaba el uso del río Negro por sobre el del río Lucac basado en los reconocimientos hechos por dos de sus oficiales.

Pacheco, en cambio, puso en duda desde un principio la utilidad de la apertura del istmo, obra que calificó como de difícil ejecución, dispendiosa y de escasa manera productiva, añadiendo que, aunque realizable, la misma debía supeditarse entre otros aspectos administrativos al establecimiento de una población en San Quintín, posiblemente en la forma de una colonia penal, que al desarrollarse justificara los trabajos en los que se pensaba9

9 Joaquín Monje, "El istmo de Ofqui" (Revista Chilena de Historia y Geografía No 105 (Julio -Diciembre de 1944), 
Fundaba sus objeciones este afamado hidrógrafo en la variabilidad de los caudales de los ríos que harían parte del trazado del canal (Lucac, Negro y San Tadeo) y su interrelación con las mareas de la laguna San Rafael; en los embanques fluviales y en la inconveniente presencia de témpanos en los cursos, entre otros aspectos que exigían estudios técnicos especializados para superar eventuales problemas prácticos. Concluía este oficial afirmando que el canal en que se pensaba solo [...] estará aprovechado por un número excesivamente reducido de goletas pues preferirán los navegantes la mar abierta a los peligros de las corriente bajos y hielos flotantes de esta nueva vía ${ }^{10}$, con lo que ponía en entredicho al principal de los beneficios esperados que proclamaban los defensores del canal.

Está visto, así, que el asunto se iniciaba controvertido, situación que se afirmaría con los años y que lo acompañaría como rasgos definitorio para la historia.

La doble comisión hidrográfica de que se da cuenta más allá de sus divergentes conclusiones instaló el tema en el ámbito naval tanto porque la materia le atañía por tratarse de la navegabilidad del sistema de aguas marinas interiores de la República, cuanto porque de modo cierto interesaba al país y en ello, directamente, al rol que a la Armada de Chile correspondía en materias ligadas a la defensa nacional y a la protección del territorio marítimo. De ese modo en vez de archivarse el asunto se lo mantuvo vigente como cosa digna de consideración, con nuevas disposiciones de caracteres técnico náutico realizadas en el transcurso de 1906 con el propósito de complementar y, en lo que cabía, precisar los antecedentes que se requerían para dar estructura formal y continuidad a un proyecto de apertura del istmo de Ofqui.

\section{Viaje del Presidente Montt a Magallanes (1907)}

Sobre esa materia, sin duda estimada trascendente, debieron tratar el presidente Pedro Montt y los jefes navales que lo acompañaban en su memorable viaje a Magallanes, en febrero de 1907. Tanto pudo interesar el asunto al ilustre mandatario que hallándose el crucero Chacabuco que lo transportaba al ancla en puerto Grafton, dispuso que se

pág. 37.

10 Id. Pág. 38 dictara el siguiente decreto:

\section{Puerto Grafton ${ }^{11}$, 18 de Febrero de 1907}

Considerando:

$1^{\circ}$-Que es manifiesta la conveniencia de facilitar la navegación desde puerto Montt a Punta Arenas por los canales australes, no sólo para impulsar el progreso de los territorios de colonización situados en sus vecindades, sino también por ser esta una vía segura para el tráfico marítimo internacional;

$2^{\circ}$-Que el Istmo de Ofqui es el único obstáculo que actualmente existe para hacer de una manera continua dicha navegación y su apertura puede llevarse a cabo por los condenados a presidio que encontrarán en este trabajo un medio de moralización y mantenimiento;

$3^{\circ}$ Que la colocación de faros y balizas en los mencionados canales, contribuirá a hacer más expedito su tráfico,

He acordado y decreto:

La Dirección de la Armada procederá a completar a la brevedad posible, los estudios y presupuestos necesarios para la apertura del istmo de Ofqui y para la colocación de faros y balizas en los canales de Chiloé, Moraleda, Smith, indicará igualmente al Gobierno el local más adecuado para instalar en las inmediaciones del Istmo del Ofqui un presidio que albergue a los destinado a la ejecución de estas obras.

Tómese razón y comuníquese. Montt. Ricardo Salas Edwards ${ }^{12}$.

Este decreto sería para la posteridad doblemente histórico: porque daba inicio formal a la iniciativa comprometiendo en ella el superior interés del Gobierno de la República en una materia de indudable importancia pública y nacional, y por haber sido dictado y firmado fuera de Santiago,

11 No obstante la consulta en las fuentes más antiguas como son las cartas hidrográficas de la Armada de Chile, el Diccionario Geográfico de Chile de Luis Risopatrón (Santiago, 1924) y el South American Pilot (editado por el Servicio Hidrográfico del la Marina de los Estado Unidos de América (Washington DC, 1920), nos ha sido imposible ubicar este topónimo que entendemos está referido a algún fondeadero del área de la península de Taitao.

12 Diario El Magallanes, edición extraordinaria del 17 de noviembre de 1939, Punta Arenas. 
en el caso en un remoto y nada conocido paraje marítimo de la Patagonia occidental central, lo que le otorga a nuestro juicio un significado especial. El mismo, está claro, reflejaba la comprensión del jefe del Estado acerca de los eventuales beneficios que podrían derivarse de la iniciativa tanto para la mejoría y seguridad de las comunicaciones marítimas entre Chile metropolitano y Magallanes y con ello para la mayor integración del mismo al país, como por la posibilidad de fomentar la colonización de aquellos sectores susceptibles de ser habitados, aspectos que Montt pondría relieve en sus conversaciones con autoridades y vecinos de Punta Arenas durante su estadía en Magallanes.

Pero más allá de la argumentación que fundaba el proyecto haciendo del mismo un factor clave para el desarrollo de la colonización y del adelanto en el vasto territorio comprendido entre el canal de Chacao y el cabo de Hornos, lo cierto es que la percepción que de él se tuvo desde un principio y por tanto la valoración que se hizo de su trascendencia, fue diferente en los territorios que habrian de ser los beneficiarios de la obra del canal de Ofqui.

Si en Chiloé la indiferencia y la ausencia de interés públicos fueron una característica constante en el tiempo, en Aysén en tanto se registró ocasionalmente algún interés de cualquier caso de menor entidad, en la medida que entre sus autoridades y sus escasos habitantes se fue acentuando la convicción de la necesidad prioritaria de abrir caminos que vincularan los sectores de reciente colonización con puertos en el litoral interior continental para los efectos de las comunicaciones, abastecimientos y salidas de sus producciones, y al fin la materia dejó de preocupar aún a los pocos que alguna vez la habían considerado, cuando se hizo evidente que el territorio litoral del sur de Aysén no parecía ofrecer una posibilidad inmediata de colonización. En Magallanes, en cambio, en particular en su centro capital Punta Arenas, donde radicaban sus autoridades, las sedes de sus empresas y la intelectualidad dirigente, el interés fue temprano y aumentó según adelantó el siglo, paradojalmente mientras se desdibujaban las posibilidades de concreción del proyecto según se verá. Tal llegó a ser el interés público, en especial durante los años de 1930 y 1940, alentado especialmente por la prensa, que contribuyó a forjar la exagerada imagen de fundar en la construcción del canal de
Ofqui y en su uso para la navegación la certidumbre de ser una posibilidad real como factor de fomento generalizado para Magallanes. La apertura del istmo de Ofqui devino así una verdadera obsesión para la generación magallánica que creció con el siglo XX.

\section{La Comisión Ofqui (1907-1910) y Proyecto de Vidts}

No bien retornó a Santiago el Presidente Montt y en cumplimiento de lo dispuesto en el decreto supremo del 18 de febrero, el Director General de la Armada, vicealmirante Jorge Montt que había acompañado al mandatario en su viaje al sur ordenó por oficio 665 de 27 de marzo la realización de los estudios necesarios para la apertura del canal de Ofqui, la formulación del proyecto respectivo y del presupuesto para su ejecución. Se encomendó la responsabilidad de esta labor compleja al ingeniero hidráulico Emilio de Vidts, de nacionalidad belga y residente en el país. Para el efecto la Armada puso a su disposición el escampavía Pisagua y la draga Rhin. El tiempo que siguió hasta el 24 de octubre de 1908 fue empleado en la colecta y lectura de los informes correspondiente a los trabajos hidrográficos de 1905, a la preparación de las naves y adquisición de los materiales, elementos e instrumental requeridos para los trabajos a desarrollar y en la selección y preparación del personal civil que debía integrarse a la expedición.

Cuando todo estuvo a punto, las naves asignadas partieron de Talcahuano el 20 de octubre de 1908 y tras recaladas de abastecimiento diverso en Corral y Puerto Montt y de embarque de más elementos y personal en Castro y Queilen, arribaron el 19 de enero de 1909 a la bahía de San Quintín, donde quedó establecida la base de operaciones.

Estas comprendieron observaciones meteorológicas, registros de mareas y corrientes en diferentes estaciones; exploraciones terrestres, levantamientos hidrográficos (sobre 7.000 sondajes) y geológicos, y faenas de dragado en San Quintín, rio Témpanos y en la laguna de San Rafael, tareas en la que se trabajó hasta comienzos de abril y a completa satisfacción del ingeniero de Vidts. El lapso transcurrido entre el retorno y enero de 1910 se empleó en la consideración de los resultados, en la formulación del proyecto y sus trabajos específicos, presupuesto incluido, y en la elaboración de 
los planos y del informe final que fue entregado la Dirección General de la Armada con fecha 10 de enero de 1910.

En lo tocante a lo sustancial del encargo, las obras de apertura del canal, nos remitimos a lo informado por el ingeniero De Vidts:

A fin de poner en comunicación por una vía de navegación, los canales al norte de la Península de Taitao con los canales del sur de esta misma península, hay que hacer los siguientes trabajos, para que buques de cinco metros de calado puedan transitar por dicha vía.

Desde la ensenada de la Bahía San Quintin, que conduce al Paso Expedición y conforme al trazado del plano correspondiente, hay que dragar un canal que tendrá cinco metros de profundidad en las más bajas aguas; seguir este grado por el río San Tadeo y Río Negro hasta llegar al Istmo de Ofqui, cortar dicho istmo en una extensión de 2.000 metros para comunicar el Río Negro con la Laguna; la entrada de dicho canal en la Laguna deberá protegerse por un abrigo Rompe-Olas hasta la profundidad de cinco metros con bloques de concreto armado, del mismo sistema que los usados en el puerto militar de Talcahuano para separación de las Dársenas; avalizarse en el canal en el Paso Expedición y Bahía San Rafael y con estos trabajos quedará transitable por agua, la vía de Leopardo a San Quintín.

Deberá recomendarse especialmente que la navegación por el río Témpanos, se haga en las horas oportunas de aguas muertas de las mareas.

La misma recomendación debe aplicarse en Paso Quesahuen donde las corrientes y remolinos son bastante fuertes en otras horas.

El valor de los trabajos consignados, está indicado en el presupuesto que se acompaña de dos millones novecientos noventa y tres mil doscientos veinte pesos oro de $18 \mathrm{~d}$.

Estos trabajos con los elementos necesarios, dos dragas poderosas y dos excavadoras mecánicas, podrán terminarse en dos años y medio a tres ${ }^{13}$.

Respecto de las bondades del proyecto, igualmente cabe conocer la ponderación hecha por De Vidts:

La ventaja principal de la apertura del Istmo de Ofqui, es abrir una vía de comunicación

13 Estudios del Proyecto de apertura del canal de Ofqui (Valparaíso, 1910), pág. 11. continua por agua y al interior de canales en su gran mayoría abrigados desde Puerto Montt hasta Punta Arenas; abierto dicho Canal se podrá establecer el cabotaje en dicha zona por los buques adecuados al objeto y se podrá sacar el provecho de las tierras que están en contacto con dicho canal, cuyos productos a la vista, son las maderas, la ganadería y la pesca.

El ferrocarril de Osorno a Puerto Montt debe terminarse en poco tiempo más; de esta manera la apertura del Istmo, formará un camino continuo dese Santiago a Punta Arenas y el intercambio de los productos nacionales entre esta región será muy pronto establecido. [...] La travesía del Golfo de Penas se hará en condiciones mucho más ventajosas, porque la navegación podrá hacerse por detrás de la isla San Javier y en consecuencia a una enorme distancia del Pacífico.

La apertura del Canal de Ofqui, dará ciertas ventajas a la Armada Nacional facilitando el paso al Sur, de las Torpederas y Destroyers, por un camino más o menos seguro; facilitará, enormemente el servicio de los faros y en especial el que está en construcción en el Cabo Raper. También facilitará, la construcción de los telégrafos al Sur, de la atención que necesitan las líneas telegráficas como medio fácil de comunicación.

Ahora, el día que se pueda ir desde Puerto Montt a Punta Arenas por el interior de los canales en vapores adecuados y cómodos, se tendrá seguramente un viaje de los más interesantes que exista en alguna parte, porque los ríos de los alrededores del Istmo son hermosos, el Ventisquero de los témpanos que se ven tan de cerca en la laguna San Rafael, son cosas que impresionan que raras veces se pueden admirar sin grandes molestias y sacrificios.

Creo que con la apertura del Istmo de Ofqui se pondría una enorme superficie del país en condiciones favorables para que sus productos puedan aprovecharse.

Es la opinión que se ha formado el infrascrito y tengo la convicción que el sacrificio pecuniario es sumamente reducido comparativamente con el beneficio que con el tiempo se sacaría de la construcción de la obra ${ }^{14}$.

Con la entrega del informe de la comisión Ofqui se había dado un paso importantísimo en la materia 14 Id. Pág. 12. 


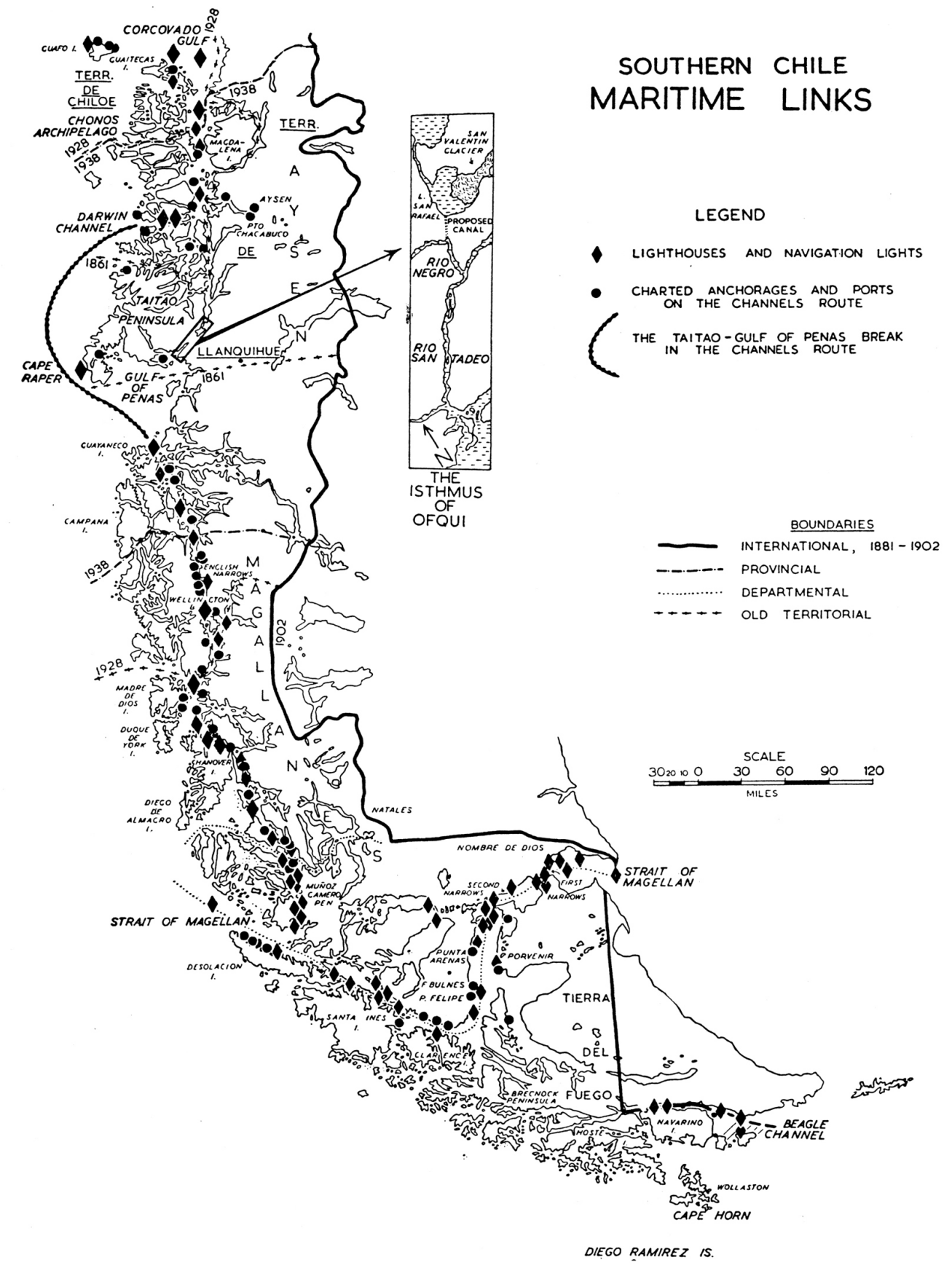

Fig. 1; Patagonia Chilena (regiones de Aysén y Magallanes), modificado de Butland 1938: la señalización marítima da cuenta de la ruta entre Puerto Montt y Punta Arenas por aguas interiores oceánicas. 
de que se trata como era el de la formulación del proyecto de apertura del canal homónimo. Tocaría a otros evaluarlo y, como se esperaba, impulsarlo en plan de su más pronta concreción.

Si este era el fruto más importante de la disposición presidencial de marras, no era por cierto el único pues en la misma ha de fundarse el proceso de intensificación y modernización del sistema de señales para la seguridad de la navegación en los mares australes, como que el mismo cobró mayor importancia a partir de 1907 de modo particular en el sector referido a la ruta intracanales patagónicos $y$ al estrecho de Magallanes ${ }^{15}$.

\section{Incertidumbre sobre la factibilidad del proyecto (1911-1937)}

Entregado el informe De Vidts el asunto entraría en un prolongado cuarto intermedio caracterizado por una fase de alternativas certezas y dudas respecto de su factibilidad y supuestas ventajas, aspecto interesante que cabe abordar desde tres puntos de vista: gubernamental, institucional (Armada de Chile) y de opinión pública.

Tocante al primero, no debiera caber duda en cuanto que el primer contraste para el proyecto hubo de ser el fallecimiento del Presidente Montt en agosto de 1910, quien debe ser tenido como alto patrocinador del mismo atendido su conocido interés por la materia, posición compartida por el almirante Jorge Montt, de prolongada permanencia en la jefatura superior de la Armada, quien siempre se manifestó favorable al proyecto pero, tal vez, no así por otros personeros del gobierno y la administración de la época. Aquel tiempo, primeros años de la década de 1910, paulatinamente fue asumiendo un carácter de inestabilidad para el país en lo económico por las repercusiones que la situación, de tensión primero y de conflicto bélico después en Europa, tuvo para las exportaciones de salitre, producto que por la vía de los impuestos sustentaba la economía nacional, que se vieron afectadas directa y principalmente por la competencia que pasó a hacerle el salitre sintético al producto natural chileno y que significó un notorio descenso

15 Para 1957 el sistema de que se trata registraba 34 faros y balizas luminosas entre la isla Guafo y el Estrecho y otras 26 en este importante paso interoceánico. Para el fin del siglo XX el sistema contaría sobre un centenar de señales. en la demanda y consiguientemente en los ingresos que las exportaciones generaban. Todo aconsejaba entonces usar de mesura en el empleo de los recursos fiscales y no gastar, entre otras cosas, sino en obras públicas de manifiesta utilidad. Esta condición debía hallarse suficientemente justificada por su respaldo técnico y por los beneficios esperados para el país. No eran tampoco aquellos los recordados tiempos del Presidente Balmaceda, el gran impulsador de obras públicas de infraestructura para el desarrollo sino, más bien, el del Presidente Ramón Barros Luco que asumió el gobierno en 1910, bajo el cual se dejó que las cosas se dieran naturalmente, sin mayores preocupaciones ni apuros, tónica parecida a la que presidió el siguiente mandato presidencial, el de Juan Luis Sanfuentes, entre 1915 y 1920.

Pero no era sólo asunto de recursos financieros y de ánimo progresista en la gestión gubernativa, sino de pertinencia de la obra en lo referido al adelanto del país como era el de las comunicaciones marítimas a lo largo de un territorio extenso y geográficamente complicado en su tercio meridional. El aislamiento de sus zonas habitadas en este caso exigía una comprensión cabal que, ha de reconocerse, sólo se ha dado históricamente de modo excepcional en los niveles superiores del gobierno nacional.

No obstante ello, fue entonces, en 1916, que el diputado Guillermo Pereira presentó a la Cámara un proyecto completo y financiado para la construcción del canal de Ofqui, iniciativa cuyo curso desconocemos pero que, es probable, quedara entrampada en discusiones y acabó por ser archivada como tantos otros proyectos sin destino en nuestra historia legislativa. No debiera quedar duda de que en tal circunstancia pudiera haber influido el conocimiento de los diputados acerca de las dudas que sobre la materia mantenía el alto mando naval, cuya opinión, está claro, era importante y vinculante para el curso de la iniciativa.

En efecto, el proyecto de que se trata, el de De Vidts, en el que debió fundarse la propuesta del diputado Pereira, parece no haber sido lo suficientemente solvente desde un principio en sus aspectos técnicos y ello afectó su evolución, retardándolo y restándole fiabilidad en particular en los ambiente llamados a pronunciarse sobre el mismo. El propio Emilio de Vidts habría contribuido a ello, en opinión posterior del ingeniero Joaquín Monje Mira, quien sin embargo de encontrarlo muy completo en lo 
referido a los trabajos de ingeniería lo juzgaba excesivamente parco en su exposición de modo que [...] el laconismo en su redacción se ha prestado a objeciones de diversa naturaleza, especialmente desde el punto de vista del aprovechamiento del Canal, por existir fenómenos fisiográficos y de carácter hidráulico que, si bien son corrientes en los países europeos, salen de la práctica del Ingeniero en nuestro país.

Los objetores, claro está, surgieron del ámbito naval en donde no debe olvidarse la discrepancia fue inicial respecto de la factibilidad y conveniencia de la apertura del istmo de Ofqui. Así fue como se sucedieron nuevos estudios complementarios con el propósito de aclarar toda duda que pudiera haber en lo tocante a la navegabilidad del futuro canal, aspecto esencial para el proyecto. Tales los derivados de las comisiones realizadas por los capitanes Armando Reyes del Río (1913), José Tomás López (1914), Gastón Kulczewski (1917) y José T. Merino (1918). Pero ni aún así fueron suficientes en el aspecto indicado ni en el de los supuestos beneficios del proyecto donde las dudas también eran especialmente importantes. Vale para el caso recordar la opinión del economista Daniel Martner al ocuparse de las características del tráfico mercantil en Chile en su libro Nuestros Problemas Económicos (Santiago, 1918) y que al abordar el proyecto del canal de Ofqui escribió que [...] solo se justifican obras de costo moderado, que no excedan de 4 a 5 millones. [...] y que se ha debido abandonar la finalidad de encauzar por los canales, la navegación entre Puerto Montt y Magallanes por ofrecer esta ruta peligro para los grandes vapores por ser además ilusoria la economía de tiempo, ya que no podría navegarse de noche, y por no prestarse los canales, estrechos y tortuosos, a las maniobras de los buques de vela ${ }^{16} .$. Esta opinión, en cuanto procede de un académico, revela cómo el asunto había trascendido al ámbito propiamente naval para instalarse en el correspondiente al del interés público.

A comienzos de 1918 la iniciativa correspondió al gobierno del Presidente Sanfuentes, cuyo ministro de Hacienda envió a la Cámara de Diputados un proyecto de ley para la construcción del canal de Ofqui basado en la propuesta técnica de una subcomisión de ingenieros para abrir una vía apta para el paso de naves de hasta 1.000 toneladas, no

16 Citado por Monje Mira en su trabajo, pág. 40. más, y con un costo de construcción estimado en $\$ 4.505 .600$ de la época ${ }^{17}$. Es claro que el proyecto se había reducido en magnitud respecto del original de 1910, para conciliar su necesidad con la opinión que parecía predominar, esto es, la de un "canal de proporciones modestas". Nada se sabe sobre el destino de esta iniciativa.

Durante los años que siguieron a 1920, tiempo de turbulencia política que sólo vino a aquietarse con la elección de Carlos Ibáñez del Campo como Presidente de la República en 1927, que en lo que importa inauguró un período de estabilidad política, tranquilidad social y crecimiento económico que se mantuvo hasta 1931, época en que las consecuencias combinada de su autoritarismo en la conducción del Estado y de la crisis económica mundial iniciada en 1929 y que afectó severamente a Chile pasado 1930, condujeron a la renuncia al cargo por parte del mandatario y abrieron un ciclo de inestabilidad constitucional que se mantuvo hasta fines de 1932, con evidente daño para la nación. Pues bien y remitiéndonos al período de gobierno de Ibáñez, el mismo se caracterizaría para la historia por su visión superior sobre el desarrollo integral del país, lo que en lo que interesa, suponía la mejor vinculación de sus zonas territoriales extremas con el centro metropolitano y su fomento económico, comprensión que condujo a la adopción de diversas medidas legales y de acciones administrativas y de gobierno conducentes a tales fines que favorecieron a Aysén y a Magallanes. En este contexto comprensivo debiera incluirse el proyectado viaje presidencial a Magallanes en el curso de marzo de $1931^{18}$, pero que debió ser suspendido por razones de fuerza mayor. Y en el mismo, quizá relacionado con el viaje presidencial y recordando lo acontecido con su símil precedente de 1907, habría podido reactualizarse -es una conjetura nuestra- el asunto de la apertura del istmo de Ofqui. Ello por la orden emanada del Ministerio de Marina, de fecha 12 de abril de 1931, de realizar nuevos estudios en el área de interés, para lo que se comisionó al capitán de fragata Gastón Kulczewski a

17 Información publicada en el diario Chile Austral, Punta Arenas, edición del 25 de febrero de 1918.

18 La prensa informó entonces que el Presidente Ibáñez se embarcaría en Puerto Montt el día 14 en el crucero O'Higgins, luego de participar en la inauguración del monumento a Galvarino Riveros en Curaco de Vélez, para seguir de allí a Punta Arenas, viaje en el que el buque sería escoltado por una escuadrilla de aviones anfibios. 
cuya disposición se puso el escampavía Sobenes. El objetivo preciso de esta comisión era el de construir un canal de experimentación a través del istmo de Ofqui que permitiera observar el comportamiento de las corrientes al intercomunicarse las aguas de la laguna de San Rafael con las del río Negro.

$\mathrm{Al}$ informar posteriormente sobre el cumplimiento de su cometido Kulczewski señaló que aunque la obra del canal era practicable [...] su utilidad era dudosa, por servir sólo un canal como el que se proyectaba, para botes y goletas, ya que un vapor, con objetivo distante, no tendría donde renovar sus fletes y no podría financiarse sin subirlos en forma prohibitiva ${ }^{19}$.

Esta nueva objeción hubo de sumarse a las varias antiguas y ser, en su conjunto, de tal entidad que hacían desaconsejable el proyecto, según debió informarlo el Departamento de Obras Marítimas al Ministro de Marina, el que por decreto confidencial número 357 de 4 de mayo de 1931 dispuso la suspensión sine die del mismo.

No debiera haber duda en que la confidencialidad de la resolución de que se da cuenta tuvo por objeto evitar el desagrado público en las provincias involucradas en el proyecto por tal razón y cualquier malinterpretación en perjuicio del crédito de la administración ya severamente cuestionada por otras causas.

El tema por tanto dejó de ser noticia, a juzgar por la ausencia de toda mención en la prensa. Pero hacia 1933 de nuevo aparecieron referencias al proyecto, lo que revela que la materia seguía en consideración. Pero antes de abordar esta nueva y ciertamente muy interesante fase, cabe contextualizar la circunstancia que así lo hizo posible.

Ocurre que avanzada la cuarta década del siglo $\mathrm{XX}$ y como consecuencia de la difusión de algunas opiniones y comentarios de personas que habían viajado a Magallanes o que mantenían alguna relación con el mismo (funcionarios públicos, periodistas) y que fueron recogidos por la prensa metropolitana del país, se fue instalando en la opinión pública la noción de estar dicho territorio virtualmente abandonado por el gobierno y la administración del Estado por causa de la ignorancia que sobre el mismo se tenía, debido a la ausencia de toda preocupación por su desarrollo y el bienestar de su población, hechos agravados por la distancia geográfica en que se 19 En Monje Mira, op. cit., pág. 42. hallaba y en situación de incomunicación práctica con el resto de Chile de Puerto Montt arriba. Tal situación, se afirmaba, había concluido por debilitar los sentimientos de nacionalidad chilena que a la larga podían incubar un ánimo separatista. Si había algunos que lo miraban con injustificada alarma a través del prisma distorsionante del chauvinismo patriotero que eran los menos, había y habría otros que apreciaban y apreciarían la situación con sensatez y reclamarían el diseño y ejecución de diferentes acciones de corto y mediano plazo que permitieran una mejor vinculación progresiva entre Chile metropolitano y Magallanes, y, de esa manera, la afirmación y vigorización de los sentimientos de chilenidad en su población ${ }^{20}$. Y en tal contexto comprensivo estaba en primer orden de preocupación la materia de las comunicaciones (marítimas, aéreas y radiotelegráficas). En el primer aspecto, es claro, se hallaba el tema de la apertura del istmo de Ofqui por cuanto de beneficioso se lo anticipaba por sus consecuencias.

El asunto tomaría desde entonces un definitivo estado público a través de la prensa, fenómeno posible de seguir a través de la revisión de las ediciones cotidianas de El Magallanes para el período comprendido entre 1931-1938 que nos ha servido de hilo conductor.

Así, la primera noticia fechada el 13 de mayo de 1933 recibida por despacho telegráfico desde Santiago, informaba que el Ministro de Defensa Nacional Emilio Bello Codecido había manifestado en audiencia concedida al Intendente de Magallanes Carlos Jara Torres, Primero: Que se estudiará la apertura del istmo de Ofqui para la mayor facilidad [de la navegación] en los mares del sur y acortar las distancias. En estos trabajos se ocupará la población penal bajo la vigilancia del Regimiento Zapadores. [...] Segundo: Será aumentada la guarnición militar de Magallanes, dotándose al Destacamento de los elementos necesarios.

La información de que se trata es importante por cuanto es la primera de carácter público tras largo silencio en la que aparece interesado y comprometido un gobierno con el proyecto y porque

20 Remitimos al lector interesado en profundizar en tan trascendente como delicada materia a nuestra Historia de la Región Magallánica (Ediciones de la Universidad de Magallanes, Punta Arenas 1992), en especial el tomo III de la reedición de 2006, capítulo II. 3 "La eclosión regionalista y la recuperación social y económica” (1932-1945). 
retoma la idea original del Presidente Pedro Montt en el sentido de ejecutar la obra de apertura del istmo con el trabajo de los presidiarios. No queda claro si la iniciativa partió del propio gobierno del Presidente Arturo Alessandri o, como parece, que lo decidido fue inducido por una propuesta hecha por el Intendente Jara Torres quien, según información inmediatamente posterior de El Magallanes disponía de antecedentes sobre la materia que puso en manos del Ministro Bello. No es aventurado pensar que estos antecedentes correspondieran a los que obraban en los archivos de la Gobernación del antiguo Territorio de Magallanes desde muchos años antes y que habían sido elaborados por el Gobernador Alberto Fuentes ${ }^{21}$.

Aunque de momento nada más se conoció sobre al asunto en lo que restaba del año 1933, es evidente que los esfuerzos soterrados que los sostenedores del proyecto hacían por mantenerlo vigente acabaron por trascender y asumir de modo definitivo estado público.

El punto de partida para esta y otras materias referidas a la situación de Magallanes fue la serie de artículos publicados en El Mercurio de Santiago por el periodista Abel Valdés tras su viaje al territorio, algunas de cuyas opiniones provocarían controver$\operatorname{sia}^{22}$. Así, en lo que interesa, escribió en la edición del día 9 de marzo de 1934:

El problema de las comunicaciones es asunto básico para el porvenir del Territorio [...] Convendría realizar el antiguo proyecto de hacer las comunicaciones marítimas por el Istmo de Ofqui, proyecto muy viejo que duerme largos años en los archivos del Congreso. La apertura del Istmo de Ofqui acortaría la navegación entre Magallanes [denominación con la que por la época se conocía a Punta Arenas] y Puerto Montt en un día, haciéndose más fácil y segura.

Para todos los trabajos se podría emplear

21 El Magallanes, 15 de mayo de 1933. Este mismo medio en su edición del 2 de marzo de 1931 al dar cuenta del fallecimiento de Fuentes recordaría en lo referido a su actuación en la materia que [...] Aunque nada se consiguió trabajó con insistencia ante la superioridad [de la Armada Nacional pues había sido oficial de la misma] por la apertura del istmo de Ofqui para hacer más corta y segura la navegación (Información titulada La apertura del Istmo de Ofqui simplificaría en mucho la navegación austral).

22 Véase al respecto nuestra obra citada, tomo III pág. 1198 y siguientes. a la población carcelaria, conmutándose en parte las penas por el tiempo trabajado 23 .

Esta opinión motivó a otros para dar a conocer sus propios pareceres sobre la materia y de ese modo en pocos días y por el mismo medio escribieron dos prestigiosos antiguos jefes de la Armada, los almirantes Luis V. López y Arturo Wilson. Ambos lo hicieron apoyando la apertura del istmo de Ofqui con los mismo argumentos conocidos entre 1907 y 1910 (época de elaboración del proyecto De Vidts), pero Wilson además agregó un decidor comentario: [...] No obstante la fácil ejecución de la obra y su costo reducido, el Senado no lo aprobó debido a la oposición de personas interesadas en el mantenimiento de la situación (j! ! ${ }^{24}$. No alcanzamos a entender lo que quiso significar con ello este alto oficial en retiro.

El gobierno del Presidente Alessandri se mostró abierto para considerar las ideas y sugerencias que hubiera en tal respecto y fue así que a fines de mayo el Ministro de Defensa Nacional solicitó al de Fomento que encomendara a la Dirección de Vías Fluviales la confección de los estudios, planos y presupuestos para la construcción de un canal en Ofqui. El encargado fue el ingeniero Joaquín Monje Mira, de solvente prestigio profesional. Tiempo después, el 1 de agosto, se designó por decreto supremo una comisión para informar oficialmente sobre el asunto, integrada por el Director General de la Armada, almirante Olegario Reyes del Río, por los ingenieros Guillermo Agüero, visitador del Departamento de Hidráulica, Joaquín Monje Mira, de la Sección Vias Fluviales del Ministerio de Fomento, y por el capitán de navío en retiro Guillermo García Huidobro. Un decreto posterior del 8 de septiembre reestructuró la comisión Ofqui dejando como miembros al almirante Reyes y al comandante García Huidobro, e integrando al ingeniero Teodoro Schmidt, Director General de Obras Públicas. Los ingenieros Agüero y Monje permanecieron en calidad de asesores.

Mientras tal ocurría, a mediados de ese mes el propio Presidente Alessandri fue informado sobre la materia en una audiencia concedida por el mandatario al diputado Rafael del Canto, quien concurrió acompañado por el gobernador de Ancud Marcial Drago y por el ya mencionado comandante

23 Reproducido por El Magallanes de la misma fecha. De la noticia se hizo eco este diario en su editorial de la fecha.

24 El Magallanes, 14 de marzo de 1934. 
García Huidobro, que para entonces era el más firme sostenedor de la factibilidad del proyecto De Vidts. Estos le hicieron saber al Presidente la importancia de la obra y sobre el hecho de haber interés en su construcción por parte de una empresa norteamericana, sin costo para el Estado, a cambio del derecho de cobro por su uso por las naves ${ }^{25}$.

Se inició de esa manera un nuevo tiempo a la espera del informe que habría de evacuar la comisión ad hoc, tiempo durante el que el asunto se instaló en los medios de comunicación, los que acogieron las diferentes opiniones tanto favorables como desfavorables al proyecto e inclusive tomaron partido por una de ambas. Así el explorador Max Junge, buen conocedor del territorio patagónico occidental central suscribió la primera postura aunque sugiriendo que la obra que debía realizarse fuera más bien un canal pequeño para el uso de lanchones y goletas [...] La apertura de un gran canal...podría realizarse una vez que nuestras provincias australes adquieran un desarrollo económico de importancia ${ }^{26}$.

Más tarde y tras un viaje a Magallanes el conocido hombre público que era Pedro Aguirre Cerda, quien ya se perfilaba como eventual candidato de las fuerzas políticas y sociales de izquierda (Frente Popular), publicaba en La Nación, el 2 de abril de 1935 un artículo de análisis sobre la situación de Magallanes, provincia que acababa de visitar, en el que daba un franco respaldo a la apertura del istmo de Ofqui como factor determinante para el mejoramiento de las comunicaciones marítimas con ese austral territorio. Luego de hacer una serie de consideraciones y de recordar las opiniones de Ramón Serrano Montaner y del almirante Wilson, que suscribía plenamente, afirmaba que había urgencia de apresurar la apertura del istmo.

Sí pues, concluía el eminente hombre de Estado, hay conveniencia económica en acercar Puerto Montt y Magallanes, la distancia se acorta en 200 millas; si con esa obra se impulsa el crecimiento de una riquísima región -la comprendida en todo el trayecto hasta Magallanes, incluida la parte continental limitrofe con Argentina-; si ese comercio vinculara esa parte del país con la aislada región de Tierra del Fuego; si con ello compenetramos económica y espiritualmente toda esa porción del territorio nacional, y damos opción a

25 El Magallanes, edición del 16 de septiembre de 1934.

26 Id., del 9 de septiembre de 1934. actividades nuevas de valor comercial susceptible de ser aprovechado por la mediana industria y por el pequeño comercio, imposibilitados hoy por el monopolio del gran productor; si la defensa nacional misma recomienda la confección de esa obra, ¿porqué dilatamos más esa empresa civilizadora, patriótica y de beneficio evidente para el aumento de nuestra capacidad productora?27.

Pero había de ser el diario El Mercurio el más tenaz y firme sostenedor de la apertura del istmo de Ofqui, en especial en el trascurso de 1935, año históricamente clave para la resolución sobre la materia, postura que afirmaba de tanto en tanto con su opinión editorial en el contexto de la preocupación nacional que merecía Magallanes para su total integración al país y por el fomento de su desarrollo y mejor bienestar de su población. Lo haría de modo particular acogiendo las opiniones de quienes defendían el proyecto de marras. Así, tocante a lo primero, basta con citar lo afirmado al ocuparse en la edición del 1 de marzo de 1935 sobre las comunicaciones con Magallanes:

La apertura del Istmo de Ofqui, proyecto por el que siempre hemos batallado con incansable tesón, serviría en parte para acortar las comunicaciones entre el centro del país y la Patagonia chilena, al mismo tiempo que permitiría la unión permanente y segura de Chiloé y Magallanes ${ }^{28}$.

A todo esto, la Comisión Ofqui había realizado su trabajo y hacia fines de mayo de 1935 se anunciaba la entrega de su esperado informe. Este se puso efectivamente en manos del Ministro de Fomento de 25 de ese mes y su autor era el ingeniero Joaquín Monje Mira. Fue un trabajo muy bien realizado, fruto del intercambio de opiniones, al parecer no siempre fácil, en el seno de la comisión, con todos sus antecedentes referidos al proyecto del ingeniero De Vidts, adicionado con otros nuevos de carácter histórico, fisiográfico, mareográfico, de navegación e ingeniería y económicos. Al cabo de una cuidadosa ponderación de los mismo el informe concluía con una recomendación al Supremo Gobierno para construir un canal de navegación a través de istmo de Ofqui

27 Reproducido por El Magallanes, edición extraordinaria de 17 de noviembre de 1939 con motivo de la visita realizada a Magallanes por el Presidente Aguirre Cerda. La materia, tratada a página completa, se presenta bajo el título de " $L a$ apertura del Istmo de Ofqui ha tenido un eficaz propulsor en S.E. el Presidente de la República".

28 Reproducido por El Magallanes de la misma fecha. 
para el uso de embarcaciones menores (vapores bajo mil toneladas brutas, goletas, lanchones y lanchas).

El estudio económico demuestra la necesidad de abrir la ruta de los Canales a la navegación vecinal. Se ha proyectado el Canal, ateniéndose a este objetivo, para barcos de cien toneladas de carga útil. Nótese que se introducía un nuevo concepto nunca mencionado antes, el de "navegación vecinal" entendida como la practicada por embarcaciones de tonelaje muy menor.

Un canal para vapores grandes (un mil toneladas) no se justifica: 1) por ser superfluo, ya que se puede, sin peligro, rodear, por el mar abierto, la península de Taitao, doblando el cabo Raper; 2) por ser la ruta interior de navegación más cuidadosa para estos vapores que la exterior, lo que introduce limitaciones y demoras en los itinerarios; 3) por no prestarse este tipo de vapores para el objetivo que se persigue o sea la atención económica y frecuente de pequeños núcleos de colonización.

El Canal proyectado por De Vidts, con plataforma de $20 \mathrm{~m}$. en el fondo, taludes de $2 \times 3 \mathrm{~m}$. de altura de base, profundidad de $5 \mathrm{~m}$. resulta por el momento exagerado; al reducir sus dimensiones en el proyecto actual, se introduce una economía considerable en el cubo por excavar y en el tiempo de construcción, conservando, al mismo tiempo, su eficacia. El cubo de excavación se ha reducido al 33\%.

Siendo el objetivo principal del Canal el fomento del desarrollo de la Zona Austral del país, sería enteramente inadecuado proyectarlo para las necesidades actuales del tráfico, sin perjuicio de que se deban consultar los dispositivos que faciliten el paso de chalupas a través del istmo mientras duren las obras ${ }^{29}$.

Las dimensiones previstas para el canal eran de 10 metros de ancho y 4 de profundidad. Con ello se dispondría de la suficiente holgura, vista además su breve longitud $(2.200 \mathrm{~m})$, su trazado recto y la estimación acerca del tráfico esperable (una goleta cada dos días). Las obras incluían la apertura del canal propiamente tal, su balizamiento y las instalaciones portuarias anexas en sus extremos; el despeje de troncos en el cauce del río Negro, el dragado del paso Expedición y el mejoramiento de la barra del

29 Op. cit. En Revista Chilena de Historia y Geografía Nº106 Enero-Diciembre de 1945, págs.62 y 63. río San Tadeo, cursos todos integrados en el sistema que debía ponerse en operación y servicio. La construcción del canal tenía un costo estimado de $\$ 20.000 .000$

El completísimo y extenso informe finalizaba con la consideración de las ventajas e inconvenientes que habrian de derivarse como consecuencia de la apertura del istmo de Ofqui. En cuanto a las primeras, las mismas podían resumirse en:

1) La seguridad de navegación por una ruta interior abrigada para embarcaciones medianas y menores.

2) La apertura a la explotación económica y a la comunicación progresivas de una zona hasta entonces muy poco accesible y desprovista de apoyo. La acción inteligente del Estado puede ser decisiva para la realización de este plan que dará término a la desocupación del territorio que puede, dentro de las tendencias modernas, hasta llegar a comprometer la soberanía nacional ${ }^{30}$.

La política de extender concesiones a favor de pequeños propietarios permitiría, también, poblar los extensos territorios del Sur del Aisén, y desarrollar actividades agrícolas e industriales en los numerosos puertos, de excelentes condiciones naturales, que se extienden a lo largo de la ruta de los canales. estas actividades serán muy provechosas, siempre que se cuenten con medios económicos de comunicación, lo que se conseguirá por medio de la apertura del Istmo de Ofqui, que se pondrá al alcance de los colonos, que se establezcan a lo largo de los Canales, los servicios económicos y flexibles de la navegación vecinal, que creará un objetivo para esa línea de navegación; por falta de esos objetivos han permanecido hasta ahora, deshabitados los canales al Sur del Aysén, limitándose las actividades, en esa zona, a campañas pesqueras o madereras con base en los puertos de Chiloé y Guaitecas, actividades volantes que han destruido más la riqueza que la que han podido explotar ${ }^{31}$.

Un centro de explotación se podría crear a la altura del estero del Baker. La Bahía de San Quintin proporciona otro emplazamiento muy favorable, siempre que la apertura del Istmo de Ofqui permita el tránsito por la vía de navegación inferior para

30 Op. cit. Revista Chilena de Historia y Geografía Nº106, pág. 100

31 Id. N 107 (Enero-Junio de 1946), pág. 313. 
acumular sus productos en Puerto Aisén.

[...] La posición geográfica de Chile es muy favorable para la próspera vida de empresas pesqueras, que en otros países dan trabajo a un personal muy numeroso; La pesca de la ballena y las industrias derivadas, como también la caza de lobos, podrían desarrollarse en forma metódica. El hecho de que nuestra costa se recorrida por corrientes de diversa temperatura, no ha sido suficientemente aprovechado para localizar los bancos que nosotros países atraen a la industria pesquera desde grandes distancias ${ }^{32}$.

3) Abaratamiento del costo de la vida en Magallanes, como factor determinante para su progreso [...] a lo cual contribuirá en forma decisiva la apertura del Istmo de Ofqui y la implantación de la línea de navegación interior, servida por embarcaciones frecuentes y económicas, que será su consecuencia ${ }^{33}$.

4) Habilitación de una nueva ruta de navegación interior que comunique a Chiloé con Magallanes que [...] abrirá a los productos agrícolas de Chiloé, especialmente al comercio de la papa, los mercados de Natales, Punta Arenas y Tierra del Fuego y liberará a los productores y consumidores de las duras condiciones a que los somete el monopolio existente de navegación y acaparamiento de artículos de primera necesidad ${ }^{34}$.

5) Reducción de la ruta de navegación entre Puerto Montt y Punta Arenas en 137 millas.

6) La importancia de proporcionar dentro del país un campo favorable para la emigración laboral de la población de Chiloé.

7) La apertura del Istmo traerá un gran impulso a las construcciones navales, pues de nada serviría una vía sin equipo; y con mercados distantes ${ }^{35}$.

8) Apertura de un campo enorme para la investigación científica, afirmación interesante por cuanto tendría de profética ${ }^{36}$.

9) La apertura del canal de Ofqui, dada la posición geográfica del mismo, habría de ser un factor de progreso para la zona austral ${ }^{37} 38$.

32 Ibid. p. 330.

Ibid. p. 316.

Ibid. p. 322

Ibid., p. 329

Ibid., p. 333

Ibid., p. 335.

Ciertamente el informe prestigia a su talentoso autor el
Los inconvenientes del canal propuesto se daban del hecho de no sustituir su apertura la navegación realizada hasta entonces por la vía exterior rodeando la península de Taitao y cruzando diagonalmente el golfo de Penas; tampoco se mejoraba el tráfico que habría de continuar condicionado por la luz diurna en algunos tramos de la navegación.

Pero, ciertamente, había un aspecto que preocupaba por igual a sostenedores e impugnadores del proyecto y era el de la navegabilidad del acceso norte del futuro canal (laguna de San Rafael) en situaciones de presencia abundante de témpanos que por entonces se daba en determinadas épocas del año, con riesgo de choque y daño para las embarcaciones. Esta suerte de "síndrome Titanic" por así llamarlo, era la consecuencia del desconocimiento acerca del comportamiento del glaciar homónimo, esto es, de su dinámica y de la generación consecuente de mayor o menor número de témpanos. Era, se reitera, un aspecto virtualmente ignorado, como lo podían ser sus consecuencias para un eventual tráfico más intenso. Y la certidumbre en tal respecto requería de observaciones prolongadas de años. Por tanto el temor de los impugnadores hacía de tal circunstancia una desventaja evidente y que los defensores no podían por entonces disipar satisfactoriamente $e^{39}$ La glaciología y su relación con la climatología del planeta era la clave del problema, pero una y otra, más todavía la primera, estaban entonces en sus fases iniciales de desarrollo.

El conocimiento progresivo del informe de la comisión Ofqui lejos de contentar a los que habían

ingeniero Joaquín Monje Mira. Bien hizo la Sociedad Chilena de Historia y Geografía en publicarlo in extenso en sus números 105 a 107 en homenaje al profesional fallecido en 1937.

39 El fenómeno del receso glaciar, mejor conocido desde hace medio siglo, daría la razón a los que relativizaban el riesgo de la presencia de témpanos en la navegación del área de que se trata. En efecto, registros efectuados por el Centro de Estudios Científicos de Valdivia (CECS) han demostrado que el glaciar San Rafael ha retrocedido diez kilómetros entre 1871 y 2003, con una pérdida de 14 km2 en su área. Ello significa que si en 1871 la lengua glaciar ocupaba dos tercios de la laguna de San Rafael y en 1905 la mitad de la misma, en la actualidad este depósito se encuentra libre de hielo en su totalidad. El fenómeno del receso ha afectado también a otros cuerpos glaciares del sector como el San Quintín, el mayor del Hielo Patagónico Norte, que sólo entre 1979 y 2003 ha disminuido su superficie en 33 km2 (Cfr. La Tercera de Santiago, ediciones de los días 14 de enero y 16 de febrero de 2007). 
aguardado una resolución favorable provocó algún malestar al entenderse su recomendación como el fruto de un acuerdo de mayoría que, sin embargo de ello, parecía haber acogido las objeciones técnicas (náuticas) y económicas que sustentaban la opinión minoritaria (almirante Reyes) y optado por la alternativa de un canal de menor capacidad que el originalmente proyectado por Emilio de Vidts. Ese hecho, en la práctica generó una polémica por la prensa que se extendió por el resto del año y se prolongó con sus ecos hasta bien entrado 1937 y en la que se vieron involucrados los principales sostenedores e impugnadores del proyecto y otros que sin tener mayores luces sobre el asunto se creyeron llamados a opinar.

Simplificando la situación, en la primera postura estaba la gente de peso técnico, histórico e intelectual como el capitán de navío Guillermo García Huidobro, ya mencionado antes, y los almirantes en retiro Arturo Wilson y Luis V. López, además de otros antiguos prestigiosos jefes de la Armada como Ramón Serrano Montaner y Carlos Bowen. Suscribieron esta posición argumental algunos ingenieros, hombres de ciencia, escritores y políticos, y le brindaron decidido apoyo diarios como El Mercurio de Santiago y Valparaíso, El Diario Ilustrado y El Imparcial, igualmente capitalinos, y El Magallanes, de Punta Arenas, principalmente. En la segunda postura se hallaban unos cuantos oficiales en servicio activo de la Armada Nacional. Tales el capitán de navío Gastón Kulczewski, por entonces comandante en jefe del Apostadero Naval de Magallanes, quien como oficial inferior había desempeñado comisiones en la zona de Ofqui; el capitán de navío Guillermo Arroyo Acuña, Gobernador Marítimo de Magallanes, y el capitán de fragata Enrique Cordovez Madariaga, quienes tenían el respaldo del Director General de la Armada, almirante Olegario Reyes del Río.

García Huidobro valorando la decisión del gobierno de Alessandri de construir el canal y reafirmando las razones ya conocidas que a su entender fundaban la obra, lamentó las opiniones en contrario expresando: [...] Son altamente inconvenientes estas actitudes discordantes con el sentir general, sea cual fuere su fundamento ya que tiende necesariamente a hacer abortar y a privarnos de los beneficios de una generosa iniciativa, muy respetable, del Supremo Gobierno, que la ha adoptado debidamente informado y con criterio y visión de estadistas sobre el amplio porvenir que una obra de tanto aliento ofrece para la navegación. [...] Deseamos también dejar constancia de nuestro criterio en el sentido de estimar improcedentes todas las críticas y todas las oposiciones que se formulen contra la apertura del Istmo de Ofqui, hoy por hoy de necesidad imprescindible, mientras no se conozcan las especificaciones técnicas de los trabajos que se realizarán, punto previo para poder calcular sus proyecciones por ahora incógnitas ${ }^{40}$.

En la misma línea argumental se pronunció el almirante en retiro Luis A. Escobar al escribir entre otros conceptos [...] Realmente, considero que nadie debe oponerse a esta obra de tanto valor para el porvenir de las regiones de los canales patagónicos y magallánicos.

Me he impuesto detalladamente de los informes, Conociendo el terreno en que los trabajos se efectuarán, veo que el informe de los señores García Huidobro y Guillermo Schmidt tiene más fuerza técnica y más valor profesional, porque estimo que las razones que se dan satisfacen ampliamente aún a quienes no conocen la zona. Es de esperar que el gobierno le dé la importancia que quiso darle el Presidente don Pedro Montt, emprendiendo la pronta ejecución de la obra ${ }^{41}$.

Pero, quien evidentemente aportó el peso de su prestigio personal y de su investidura corporativa fue el almirante Wilson en su calidad de Presidente de la influyente Liga Marítima de Chile y por ello fue directo y preciso en su referencia a la opinión desfavorable de la Armada de Chile en la materia:

La Liga Marítima de Chile después de impuesta de los informes de mayoría y de minoría de la comisión nombrada por el Ministerio de Fomento para estudiar la apertura del Istmo de Ofqui, ha creído convenientemente dar su última opinión [...], sin que esto pueda significar una polémica o crítica apasionada, pues creemos que a todos nos impulsa el mejor deseo de servir al país.

En esta circunstancia debe tenerse presente que la Liga Marítima de Chile fue la iniciadora de la propagada para remover este proyecto que parecía abandonado definitivamente.

Es sensible para la Liga Maritima de Chile encontrarse en desacuerdo con la Superioridad

40 El Magallanes, 11 de junio de1935, información titulada Las esperanzas de Magallanes no serán defraudadas.

41 El Magallanes, 4 de julio de 1935 
Naval, puesto que nos veremos obligado a tratar conforme a nuestro criterio.

Desde un principio, y después de algún tiempo de consideración se resolvió publicar algunos artículos de propaganda, aprovechando una publicación que hacía la necesidad de vincular a los habitantes de Magallanes al resto de las provincias del norte, y estimando que uno de los factores principales era evidentemente la apertura del istmo de Ofqui, se hacía presente la sorpresa que nos había causado la opinión contraria de marinos en una obra que parecía tan natural que fuera acogida con entusiasmo por ellos, siendo uno de los estudios que ha dejado como herencia la Administración de nuestro glorioso Almirante Montt.

[...] Lo que más llama la atención en el informe de la Superioridad Naval es el panorama pavoroso con que pinta las dificultades y los riesgos que ofrecerá la navegación, teniendo que afrontar el inconveniente de las corrientes y de las mareas llevando consigo peligrosos témpanos, y además la acumulación de éstos en las bocas de los desaguaderos de la Laguna San Rafael, y aún más, el embancamiento del paso de expedición del Río San Tadeo, que obligarán el dragaje y el abalizamiento que exigirían a la Armada cuantiosos gastos por anclaje cadenas, dragas, etc., todo lo cual constituirá una enorme carga para su presupuesto anual aumentando así los cuantiosos gastos de la Nación.

Todos estos detalles son simple literatura destinada a producir alarma para una opinión contraria a la obra proyectada y también estima que se podría transigir en el proyecto reducido por la mayoría de la comisión ${ }^{42}$.

Entre las varias entidades y personas que apoyaban el proyecto cabe mencionar al Centro de Oficiales de la Marina Mercante, de Valparaíso, a la Cámara de Comercio de Puerto Montt, al reputado geólogo Dr. Juan Brüggen y personalidades y organizaciones de Magallanes según se verá en el siguiente apartado.

El principal sustento de la opinión en contra del canal de Ofqui estaba en la opinión del capitán de navío Gastón Kulczewski. De sus varias intervenciones en la prensa debe mencionarse el artículo titulado "El Canal de Ofqui", publicado en la edición del 14 de julio de 1935 de El Magallanes. En este

42 El Magallanes, 13 de julio de 1935.
Kulczewski discutía las supuestas ventajas comerciales del proyecto, una vez concluidos los trabajos, para el movimiento entre Magallanes y Chiloé, y afirmaba que el mismo no sería en absoluto conveniente por su baja potencialidad y por la extensión de la ruta marítima; otro tanto opinaba respecto del previsto acortamiento de la navegación afirmando que lo que se ahorrara en millas se perdería en tiempo a la espera de condiciones favorables para continuarla por la nueva ruta. Respecto de la colonización del área desmentía cualquier poblamiento vigente a la época como alguno había afirmado, amén de discutir cualquier posibilidad futura dada la severidad climática del ambiente natural patagónico occidental y, por fin, que la obra en proyecto no habría de reportar ningún beneficio para la mejor comunicación de Magallanes con el resto del país, Su opinión en este aspecto específico era precisa y clara: Magallanes requería de una comunicación marítima segura, rápida y económica con el centro del país en tal forma que en tres o a lo sumo en cuatro días se esté en Santiago, tanto en materia de carga como de pasajeros y esto se conseguiría estableciendo una línea de vapores rápidos (18 millas de andar efectivo) que, partiendo de Punta Arenas llegaría a P. Montt en 48 horas. Esta linea produciría pérdidas y tendría naturalmente que ser subvencionada por el Gobierno garantizándole a la Compañía una utilidad determinada ${ }^{43}$.

Pero, sin duda alguna, la determinante para la posición de que se trata fue la opinión del almirante Olegario Reyes y para ello basta con mencionar lo que manifestara en entrevista concedida al diario El Mercurio de Santiago al ser consultado en tal respecto:

Los barcos mercantes que navegan entre el Archipiélago de Chiloé, Aysén, Puerto Montt y Magallanes no tienen interés en la ruta proyectada. Igualmente, los buques de la Armada no emplearian dicho canal, habiéndose decidido definitivamente

43 Sus contradictores reprochaban a Kulczewski su ligereza de juicio y su obcecación en la materia, pero también en especial los oficiales de la Armada le achacaban su proceder de 1931cuando en cumplimiento de una comisión expresa en Ofqui encomendada por el Ministro de Marina la cumplió con una permanencia efectiva de menos de ocho horas, en circunstancia que un desempeño acucioso le habría obligado a permanecer varios días en el lugar. Ello aparte de que, como se ha visto antes, su informe fue negativo y condujo a la suspensión del proyecto por parte de la Marina. 
la ruta del Cabo Tres Montes, por fuera ${ }^{44}$.

Una aseveración así de categórica no podía ser refutada fácilmente e indudablemente restó fuerza a la propuesta de la Comisión, aún cuando su parecer tuviera un carácter minoritario.

La polémica se fue tornando así en cosa ingrata para sus intervinientes y acabó fastidiando a más de alguno, como fue el caso de García Huidobro que no dudó en afirmar que [...] Tratándose de una iniciativa del propio Gobierno estimo que el asunto del Istmo de Ofqui debe tratarse en los círculos científicos como el Instituto de Ingenieros de Chile y no en los círculos sociales ${ }^{45}$.

En fin, a qué seguir en el relato de una controversia que para entonces y por largo tiempo más era y sería un verdadero diálogo entre sordos, lo que exige poner término a la referencia.

A todo esto y mientras así había sucedido y sucedia, la recomendación de la Comisión Ofqui proseguía su curso burocrático camino de convertirse en un proyecto en forma para los efectos de su más pronta realización. De esa manera, resumiendo, a fines de junio de 1935 se informaba del nombramiento del ingeniero Finn Bühring, especialista en obras fluviales, para asumir la responsabilidad del proyecto; el 17 de julio la noticia daba cuenta del próximo viaje de una misión técnica a Ofqui a cargo del ingeniero Joaquín Monje con el fin de realizar algunos estudios complementarios, cuyo trabajo concluiría en octubre. El mismo se refería a las eventuales dificultades que podría presentar la barra del río San Tadeo a la navegación por el canal. Resuelta la duda y aprobado el informe de Monje el Director General de OO.PP. Teodoro Schmidt anunció (30-X-1935) que el Gobierno resolvería sobre la obra durante el próximo mes de diciembre a fin de solicitar del Congreso los recursos para el efecto.

A su tiempo el almirante Reyes -que para entonces parecía un aguafiestas- declaraba al corresponsal de El Magallanes en Santiago que [...] la realización del trabajo del Istmo es sumamente hacedera [...] pero respecto a los beneficios que dicha apertura traerá para esta región [Magallanes] estoy convencido que serán nulos como ya muchas veces lo he manifestado por la prensa del pais ${ }^{46}$.

Para comprender la demora que tomaba

$44 \quad$ El Magallanes, 27 de junio de 1935.

45 El Magallanes, 24 de julio de 1935.

46 El Magallanes, edición del 5 de diciembre de 1935. el asunto es preciso contextualizarlo en la cuestión más amplia de la comunicaciones con Magallanes y la mayor integración del mismo al país -que era la preocupación principal del gobierno de Arturo Alessandri y de la opinión pública-, de modo que visto así la apertura del canal de Ofqui era sólo una de las alternativas, pues las otras dos eran la comunicación aérea y la navegación mercante eficiente. Estas tenían su correspondiente sustento en la Fuerza Aérea de Chile, directamente involucrada en el proyecto de la primera, y en la Armada Nacional que actuaba como una suerte de patrocinadora de la segunda sin comprometerse institucionalmente en ella. De esa manera el gobierno de Alessandri en el hecho se vería presionado desde distintos frentes durante el lapso 1933-1938 a favor de alguna de estas alternativas, situación que es claro retardaba su decisión definitiva en la espera de una elección acertada que de verdad satisficiera al interés nacional. Aunque ninguna de ellas era excluyente respecto de la otra, pudiendo inclusive complementarse, la cuestión estuvo dada por la prioridad que debía darse y la disponibilidad de los consiguientes recursos a utilizar en su ejecución.

Tocante a la vinculación aérea entre el extremo austral de Chile y su zona metropolitana, tras el fracaso del primer intento de 1930 la Fuerza Aérea de Chile elaboró a contar de 1934, luego del exitoso doble raid del comandante Arturo Meneses entre Santiago, Puerto Montt y Punta Arenas, de ida y regreso, un plan para establecer bajo su responsabilidad y tuición un servicio aéreo experimental de pasajeros y carga dotado con hidroaviones pues la ruta elegida era la del sobrevuelo del sistema de los canales patagónicos. El esfuerzo proyectado fue complementado con una política comunicacional a través de la prensa destinada a ganarse a la opinión pública y, va de suyo, el apoyo gubernativo ofreciendo el servicio como una respuesta técnica moderna, que parecía muy eficaz, a una exigencia de interés nacional.

Así, tras varios estudios, ensayos y algunos contrastes pudo finalmente ponerse en servicio en abril de 1937 la "Línea Experimental Puerto Montt-Magallanes", para cuya operación se habían adquirido en Estados Unidos dos hidroaviones Sikorsky. La operación regular se inició y prosiguió con normalidad ante la expectación pública y sobre todo con el aplauso de la población magallánica, pero 
cuando se contaban veintiséis vuelos un siniestro que afectó al hidroavión Chiloé mientras sobrevolaba la zona próxima a la isla Huafo, causó su pérdida y la muerte de todos sus pasajeros y tripulantes, tragedia seguida a los pocos días por otro accidente que dejó fuera de uso al hidroavión Magallanes. Ese doble contraste condujo a la suspensión del servicio por la falta virtual de material de vuelo y restó crédito público a la iniciativa que debería aguardar casi una década para recobrar vigencia, que entonces sí sería exitosa.

La otra alternativa era la de modernizar la comunicación marítima, esto es, la de brindar a Magallanes y, por extensión, a toda la región patagónica occidental un servicio eficiente usando la ruta tradicional, determinado por la calidad de las naves (tamaño mayor, adecuado tonelaje y andar rápido que permitiera hacer el trayecto Punta Arenas-Puerto Montt en dos días de navegación; suficiente capacidad de carga y comodidades para pasajeros), la regularidad y periodicidad programada del servicio y su economía (fletes y pasajes). La idea, de antigua data en el ambiente magallánico, se reactualizó en la época de que se trata y fue auspiciada por la Armada de Chile, en el supuesto que su realización debía corresponder a la esfera empresarial privada y, -descontándose su falta de rentabilidad económica-, con una subvención estatal, acompañada de una exigencia de garantías para la debida cautela del interés de los usuarios.

Al cabo de una sostenida campaña de prensa en su favor, en la que se tuvo el cuidado de aclarar que debía verse en ella un complemento y no una alternativa excluyente del canal de Ofqui, durante 1938 el asunto adelantó tanto como para que oficialmente se anunciara por el gobierno de Alessandri la decisión de adquirir tres unidades de alrededor de 3.000 toneladas cada una para el establecimiento del servicio y unas cinco o seis con capacidad menor para la atención del área Chiloé-Aysén. La responsabilidad sería asumida por la Empresa de Ferrocarriles del Estado que para el efecto crearía un departamento marítimo. Volveremos sobre el curso de esta iniciativa.

Y retornando a la materia principal, no obstante lo informado en su oportunidad, llegó diciembre de 1935 sin que hubiera noticias sobre la materia por parte del Ministerio de Fomento. Así, en compás de espera, se llegó a marzo de 1936 y se conocieron nuevas informaciones que por una parte daban cuenta del envío en mayo de un proyecto del Ejecutivo al Congreso en procura de fondos para su ejecución, y, por otra, que se habían encomendado al ingeniero Bühring más estudios complementarios para la obra.

Pero transcurrió el tiempo otra vez sin más noticias sobre el asunto, lo que lleva a suponer que la discusión entre partidarios y opositores se mantenía soterrada en el más alto nivel, a juzgar por lo escrito por El Mercurio de Valparaíso en su edición del 16 de octubre de 1936: Todavía se discute y con gran calor si conviene o no para las comunicaciones la apertura del Istmo de Ofqui. Mas ni esa prevención, ni otras opiniones en apoyo del proyecto como fueron, entre varias, la de Ricardo Salas Edwards, antiguo Ministro de Marina en el gobierno de Pedro Montt, quien había acompañado al Presidente en su memorable viaje a Magallanes en febrero de $1907^{47}$, la del diario El Imparcial de Santiago, que en editorial del 26 de junio de 1937 afirmó que El canal de Ofqui será un factor poderoso para intensificar la navegación a Magallanes ${ }^{48}$, opinión reiterada en edición del 24 de julio, parecieron por entonces suficientes como para ayudar a destrabar el asunto.

Finalmente, cuando más de alguno podía haber perdido las esperanzas ante tanta dilación el 2 de agosto el Ministro de Fomento informaba a la prensa acerca de la decisión definitiva del Gobierno de construir el canal de Ofqui. Conocida la noticia el comandante García Huidobro telegrafió al Director de El Magallanes puntualizando: La apertura de Ofqui representa un triunfo nacional al cual hemos contribuido con patriótico interés, al compartir su satisfacción con un medio que invariablemente había respaldado la iniciativa.

Por su parte El Mercurio de Santiago, otro de los paladines de tan prolongada campaña de apoyo, escribió editorialmente en su edición del día 3 de agosto: No puede menos de celebrarse la decisión del Ministro de Fomento que resuelve en forma acertada un anhelo largamente acariciado por los interesados de la zona austral de Chile y

47 Hace 30 años que se decretó la apertura del Istmo de Ofqui, recordaría el antiguo secretario de estado a El Imparcial del 10 de julio de 1937.

48 Reproducido por El Magallanes de 26 de junio de 1937. 
por toda la opinión pública del país ${ }^{49}$.

Que la cosa no había sido fácil, ni al parecer todavía lo era, queda a la vista tras las nuevas opiniones adversas expuestas al Ministro por los comandantes Guillermo Arroyo y Enrique Cordovez a nombre de la Armada de Chile ${ }^{50}$. Pero esto pareció ya ser suficiente para el gobierno del Presidente Alessandri, como que el 13 de agosto el Ministro de Fomento creyó necesario responder a esos oficiales, manifestándo que las razones de la Marina ya habían sido consideradas en su momento y que el canal se construiría cuanto antes, una vez se dispusiera de los fondos para la obra.

Para remachar la decisión, días después, el 25 de agosto, la prensa nacional informaba que el Director General de OO.PP. ingeniero Teodoro Schmidt instalaría los trabajos del canal, cosa prevista para fines del año, información reafirmada editorialmente por El Mercurio con una nueva prevención: Es obligación perentoria del Gobierno no aceptar que se obstaculice la construcción del canal en Ofqui, recordando para el caso lo que escribiera en ese mismo medio el almirante Luis V. López en $1914^{51}$.

Ya no había más vueltas que darle al asunto: el canal sería una realidad. Habían pasado treinta años desde la iniciativa del Presidente Montt.

Ambiente público en las provincias involucradas en el canal

Desde que se planteó por vez primera la iniciativa y en adelante, siempre se entendió que la misma debía interesar a la vasta macro región austral de Chile, esto es, a los territorios de Chiloé, de Aysén y de Magallanes. Sin embargo, igualmente desde un comienzo el interés público en cada una de estas regiones fue distinto y proporcional a la distancia del punto geográfico tenido como focal en la materia, Puerto Montt, en tanto que puerta de entrada y de salida del territorio metropolitano de Chile, según se accediera viniendo desde o yendo hacia el austro chileno.

Aunque las informaciones y antecedentes compulsados para el trabajo que nos ocupa se relacionan más con Magallanes, menos con Aysén y

\footnotetext{
$49 \quad$ El Magallanes, 2 de agosto de 1937.

50 El Magallanes, 12 de agosto de 1937.

51 El Magallanes, 30 de agosto de 1937.
}

sólo en lo mínimo con Chiloé, en este último caso debe convenirse que el interés de su población por la materia, -habilitación de un paso marítimo a través del istmo de Ofqui para de esa manera vincular más directa y seguramente a la provincia norteña con su par meridional-, era harto escaso, si lo hubo, y en este caso tal vez no haya pasado más allá de alguna de sus autoridades gubernativas y de una que otra noticia o comentario en la prensa local. Así pues, consideramos que para Chiloé el asunto resultaría irrelevante en el tiempo de vigencia de la iniciativa frente a otras materias de más acuciante interés público referidas a la superación de su infradesarrollo y de los problemas derivados.

Para Aysén, territorio incorporado a la vida y actividades nacionales con el comienzo del siglo XX, el asunto pudo importar en cuanto la iniciativa de que se trata lo favorecía al brindarle la posibilidad de las comunicaciones marítimas para la continuidad y desarrollo de la empresa colonizadora $y$, por otra parte, le significaba abrir zonas litorales desconocidas a dicho proceso. Pero la realidad histórica de lo acontecido allí da cuenta de que si bien las concesiones fundiarias que abrieron el territorio a la colonización partían desde el litoral interior continental extendiéndose por entre las montañas andinas hacia los espacios ultracordilleranos del oriente, fue en estos, fácilmente accesibles por lo demás desde suelo argentino, donde se concentró el esfuerzo poblador empresarial y el individual, espontáneo y libre de chilenos que ingresaron desde allende la frontera internacional. En ese proceso laborioso, esforzado, prolongado, casi titánico y épico desarrollado con gran intensidad entre la primera y cuarta décadas del siglo XX en su fase pionera que dio vigencia institucional al territorio patagónico norcentral de Chile desde Futaleufú por el norte hasta el lago San Martín (O'Higgins) por el sur, si hubo algo que concitó el interés máximo público y privado, del Estado y sus autoridades, de empresarios, colonos y de la población que crecía en número, era lo de una comunicación expedita con Chile metropolitano -entendida siquiera como un camino o senda practicable-que intercomunicara a los espacios en fase de poblamiento con un puerto habilitado en el litoral interior y, complementariamente, lo de disponer de un servicio de navegación regular para asegurar las comunicaciones personales e institucionales, el abastecimiento general y la salida 
de la producción económica. En ese bien acotado contexto de geografía, tiempo y circunstancias, la propuesta de apertura del istmo de Ofqui fue del todo irrelevante en el lapso de que se trata.

En cuanto a Magallanes, ciertamente el caso fue distinto desde principio y, con el mejor dominio de la información en su respecto pasamos a su consideración.

Sin embargo de que en lo referido a la primera fase de la iniciativa, comprendida entre el tiempo final del siglo XIX y 1930, la información encontrada es escasa, sabemos que el asunto interesó primero a las autoridades territoriales y a oficiales de la Armada Nacional, en especial luego de la memorable visita del Presidente Pedro Montt en 1907, tanto como para que el Gobernador Alberto Fuentes, antiguo marino, elaborara un completo informe en apoyo de la idea de la apertura del istmo de Ofqui que fue elevado a la consideración del Supremo Gobierno y, suponemos, también de la jefatura de la Armada. Pero, al parecer y en la tónica caracterizadora de esa etapa histórica del proyecto la materia no trascendió a la opinión pública ${ }^{52}$.

Valga para el caso lo que escribiera el periodista Manuel Zorrilla en su obra Magallanes (Punta Arenas, 1925):

Sobre esta obra de reconocida importancia para las provincias australes existen estudios, planos y presupuestos que fueron acompañados a un proyecto de ley que se presentó oportunamente al Congreso.

Permitiría la navegación de naves de pequeño tonelaje (hasta de 1.500 toneladas), evitando la molesta travesía por los mares de la Península de Tres Montes y acortando notablemente la distancia.

El costo de la obra no sería muy crecido; los trabajos son de fácil realización.

Además de los beneficios, ya anunciados, el canal de Ofqui daría vida activa a extensos territorios que en la actualidad se ven estagnados en su fácil producción agrícola y maderera por la falta de medios de comunicaciones ${ }^{53}$.

Si el asunto no había concitado mayor interés por la época, sí que lo haría pasado 1930. Es que la situación regional había cambiado notoriamente

52 Se han encontrado referencias en los diarios El Magallanes de 3 de noviembre y 21 de diciembre de 1916, y Chile Austral del 25 de febrero de 1918.

53 Tomo II, p. 200. entre las dos primeras décadas del siglo y los años iniciales de la tercera. En efecto, de haber sido Magallanes autosuficiente y autónomo en lo tocante a la satisfacción de sus necesidades, especialmente en lo referido a su abastecimiento de bienes de consumo, intermedios y de capital para el desarrollo de las actividades económicas, y a la colocación de su producción (principalmente, lana, carne y derivados), gracias a su temprana inserción en el sistema internacional de división del trabajo, y a su íntima y tradicional relación con Europa que había contribuido a su poblamiento mediante la inmigración y que influía con sus ideas en su evolución civilizadora, de pronto, llegado 1920, se encontró en una situación casi diametralmente opuesta. Ello porque la situación vigente en época de normalidad hasta 1914, tiempo del estallido de la Gran Guerra Europea (Primera Guerra Mundial), se alteró completamente a contar de la postguerra, cuando además se hicieron sentir las consecuencias de la apertura del canal de Panamá en la navegación interoceánica a través del estrecho de Magallanes que había brindado a Punta Arenas y al territorio un eficiente y beneficioso servicio regular de comunicaciones marítimas. Entonces, perdida tan privilegiada vinculación con el Viejo Mundo y el antiguo ordenamiento mercantil internacional, Magallanes entrados los años de 1920 pasó a mirar para la satisfacción de todas sus necesidades hacia el centro metropolitano del país, del que había permanecido virtualmente al margen. Y en tal coyuntura el peso de la geografía que lo aislaba se hizo sentir quizá como nunca antes. Superar esa situación mejorando las comunicaciones y cuanto las mismas significaban en abastecimientos y otros aspectos indispensables para la vida y la economía, pasó a ser de necesidad apremiante. Y tratándose de comunicaciones las marítimas estaban en la primera prioridad en tanto que por entonces eran las únicas practicables, excepción hecha de la telegrafía (alámbrica e inalámbrica) cuyos beneficios se habían incorporado desde el principio del siglo. Y allí, en ese contexto, encajaba el tema del canal de Ofqui.

Así entonces, el asunto interesó en primer lugar a las autoridades políticas, como que el Intendente Carlos Jara Torres (1932-1934), según se ha visto, enterado del informe que su predecesor Alberto Fuentes elaborara en su hora, planteó al Ministerio de Defensa Nacional en el gobierno del Presidente Arturo Alessandri, Emilio Bello Code- 
cido, la conveniencia de reactualizar la materia y adoptar una resolución que la activara camino de su concreción (1933). Sin embargo al parecer ninguno de sus sucesores prosiguió con esa preocupación y sólo recién en marzo de (1937) el Intendente general René Ponce del Canto (1936-1937) retomará el punto según se verá.

En un nivel jerárquico inferior la Municipalidad de Punta Arenas, en tanto que vocero democrático legítimo de la comunidad, respaldó decididamente el proyecto de apertura desde que el mismo tomó estado público, y más aún quien la presidía, Ernesto Pisano Blanco, primer alcalde electo de la capital magallánica (1935-1938 y 19381941). Sirvan como testimonio sus declaraciones a El Mercurio de Santiago, hechas en julio de 1935, con oportunidad de una visita a la capital:

Los Poderes Públicos están decididos a favor del establecimiento de las comunicaciones aéreas entre Magallanes y el centro del país, y puede afirmarse que los progresos de la aviación serán ventajosamente aprovechados, a fin de mejorar y facilitar las actividades productoras de esa valiosa zona, poniéndola más al alcance del Gobierno Central.

También domina el pensamiento de avanzar para que cuanto antes sea posible, en la realización de la apertura del Istmo de Ofqui, obra utilísima que habría debido y podido llevarse a cumplido término desde hace muchos años, a no mediar las incomprensiones, los temores y las lentitudes tradicionales, que parecen ser condición ineludible en nuestro país para toda empresa de cierta importancia.

Felizmente las opiniones favorables del comienzo, sobre el referido Istmo, van imponiéndose a la precisión del Gobierno y del Congreso y no puede dudarse que la mayoría de la opinión pública propicia también la iniciación de esta idea de efectiva conveniencia nacional ${ }^{54}$.

De las organizaciones sociales de la época cabe destacar el apoyo del entonces poderoso (por su convocatoria vecinal) Partido Regionalista de Magallanes y de la Legión Cívica de Magallanes que le diera origen; del Touring Club de Magallanes y del Rotary Club de Punta Arenas (aunque con reservas), también de periodistas y escritores conocidos $\mathrm{CO}^{-}$

54 Reproducidas por El Magallanes en su edición del 27 de julio de 1935. mo Pedro León Ballester, Manuel Zorrilla y Lucas Bonacic Doric, entre otros varios. Pero, por lejos, fue el vespertino El Magallanes, con su director el abogado Alfredo Andrade Bórquez, a la cabeza, el campeón de la apertura del istmo de Ofqui, devenida verdadera causa popular atendidos los beneficios que se esperaba brindaría a Magallanes. De esa manera, entre 1933 y 1944, por señalar el lapso de mayor intensidad informativa, este órgano ofreció noticias y elaboró comentarios a favor de la propuesta que tanto sirvieron para mantener informada a la comunidad regional, cuanto contribuyeron a alinearla mayoritariamente en respaldo de la materia formando opinión, sobre la materia. Fue una posición sostenida, franca, vigorosa y digna de ser destacada ${ }^{55}$.

Sin embargo de ello, no se crea que por entonces se dio unanimidad de pareceres sobre el asunto, pues si hubo quienes lo apoyaron, otros no, bien porque lo estimaran irrelevante o bien por creerlo insuficiente para el desarrollo regional, contándose unos terceros que disponiendo de información general sobre el proyecto original (De Vidts) no se conformaron con la propuesta de construcción de un canal de menor capacidad (proyecto ingeniero Monje). De esa discrepancia darían cuenta para la historia un grupo de alumnos memorantes del Instituto Comercial de Punta Arenas en una obra conjunta de la época referida a la región, Magallanes en su primer centenario, (Punta Arenas, 1944), al escribir que en la postura favorable al proyecto estaban la Municipalidad de Punta Arenas, los partidos políticos (Regionalista, Socialista, Radical entre otros), y el diario El Magallanes; y en la postura contraria (postergación de las obras del canal) el Apostadero Naval, la Cámara de Comercio e Industria de Magallanes y el diario La Prensa Austral, como los intérpretes más calificados de opinión.

Entre ambas posturas, la autoridad gubernativa superior, el Intendente -función servida en la época por personajes por lo común anodinos y sin compromiso con la comunidad habitante-, se situó en un plano intermedio o posición neutral que tanto pudo reflejar su indecisión como su insuficiencia de información sobre la materia. Sirva de ejemplo

55 Al respecto entregamos el siguiente dato acerca de las referencias publicadas sólo entre 1931 y 1938 sobre la materia (desde informaciones simples hasta artículos de página completa y más): 1931 (1), 1934 (13), 1935 (39), 1936 (4), 1937 (25) y 1938 (4). 
la circular enviada por el general René Ponce del Canto a los presidentes de diferentes instituciones de Punta Arenas, en la que requería su parecer sobre el asunto, en especial acerca de las ventajas esperadas de la apertura del canal. Ello, es de suponer, para fundar una propia sobre el tema e informar con posterioridad al Supremo Gobierno (El Magallanes, 24 de marzo de 1937).

Para concluir el parágrafo y en procura de la mayor objetividad viene al caso recordar la opinión entregada a la comunidad por el Rotary Club de Punta Arenas, a través del informe elaborado por una comisión ad hoc que recogiendo los distintos argumentos que sustentaban las posiciones divergentes en procura de una opinión equilibrada y neutral, hacía una interesante mención a dos puntos medulares del asunto:

Antes de terminar conviene advertir, todavía, que aquí, en Magallanes no se ha producido nunca el clamor público que reclame esta obra como parece desprenderse de algunas informaciones de la prensa de la capital, ni mucho menos ha podido formarse entre la gran masa popular una aspiración consciente en el mismo sentido. Se comprende en seguida que un problema de esta naturaleza, de carácter casi exclusivamente técnico no pueda vulgarizarse hasta el punto de convertirse en el concepto público como un postulado regional.

[...] En realidad, el problema fundamental de la vinculación económica y espiritual de Magallanes con el centro del país, es el problema de las comunicaciones rápidas, regulares, baratas entre Magallanes, Puerto Montt y Valparaíso. Para el que tiene un conocimiento personal y profundo de las condiciones peculiares de este Territorio y de sus necesidades resulta incomprensible cómo se pueda sostener el absurdo geográfico, técnico, político, administrativo y comercial de que la apertura del Canal de Ofqui, grande o pequeño, pueda resolver o contribuir siquiera, en una parte mínima a la solución de una parte mínima a la solución de un problema de tanta magnitud ${ }^{56},{ }^{57}$.

56 El Magallanes, 23 de julio de 1935.

57 Advertimos una notoria semejanza conceptual y argumental entre el contenido de este informe y el artículo que por entonces (véase la nota 43) publicara el capitán de navío Gastón Kulczewski, comandante en jefe del Apostadero Naval de Magallanes y principal opositor al proyecto de apertura del canal de Ofqui. Ello sugiere que o bien los redactores del informe trataron el punto con este jefe o bien leyeron
En suma, están a la vista la consideración que mereció y el interés que la materia despertó en el seno de la comunidad magallánica, tanto como para conservar en la memoria histórica de un par de generaciones de sus integrantes la noción de la apertura del istmo de Ofqui como factor eventual del adelanto regional, si la obra llegaba a concretarse.

\section{OBRAS SDE CONSTRUCCIÓN DEL CANAL DE OFQUI (1938-1943)}

\section{Comienzo y desarrollo de los trabajos}

Conocida la decisión del gobierno de Alessandri de ejecutar la obra, a más de alguno pudo parecer natural que la Dirección General de Obras Públicas encomendara su responsabilidad al profesional que sin duda mejor se había identificado con ella, el ingeniero Joaquín Monje Mira, tanto por su conocimiento profundo sobre sus antecedentes, cuanto por su personal experiencia en el terreno geográfico donde debía realizarse y por el convencimiento que tenía respecto a su utilidad y a los beneficios esperados para la región austral. Pero por entonces, segundo semestre de 1937, Monje estaba enfermo de gravedad, como que fallecería el 14 de febrero del año siguiente, deceso recibido con sentimiento de pesar por su valía profesional y humana. De modo que se eligió para tal responsabilidad al ingeniero Ángel Zanghellini, quien hasta entonces se había desempeñado como jefe de la inspección técnica de la construcción del túnel ferroviario Las "Raíces", importante obra pública de la época ${ }^{58}$.

Sobre la base de la revisión de la prensa cotidiana lo ocurrido a partir de entonces y hasta marzo de 1938 puede resumirse así: el Director General de OO.PP. Teodoro Schmidt había decidido

con detención su artículo de marras. No podría excluirse la posibilidad de que Kulczewski fuera socio o concurrente habitual a las sesiones de la entidad como ha solido ocurrir con muchos funcionarios y jefes de servicios públicos en el historial institucional.

58 El Magallanes, información del 24 de septiembre de 1937. El túnel "Las Raíces" formaba parte del trazado de la línea ferroviaria internacional que debían unir a Talcahuano, en Chile, con el puerto de Bahía Blanca, en Argentina. Esta obra de antigua data en cuanto proyecto era anhelada tanto por los gobiernos de Chile como Argentina, sin embargo su construcción había demorado y finalmente permanecería inconclusa para siempre con punta de rieles en Curacautín, del lado chileno, y en Zapala del argentino. 
concurrir personalmente a Ofqui para solemnizar la instalación de faena de las obras. Se preveía la contratación de unos sesenta obreros y el empleo de maquinaria para su ejecución, disponiéndose de un presupuesto inicial de $\$ 25.000$ para los trabajos fundacionales. Estos adelantaron satisfactoriamente a contar de octubre o noviembre, informándose a fines de diciembre sobre la contratación de más personal y del envío de maquinaria para la obra del canal propiamente tal. Para febrero de 1938 ya se había construido el campamento y el embarcadero (San Rafael) y los trabajos avanzaban favorecidos por el buen tiempo, cosa inusual en el área. Se anunciaba entonces la visita del Ministro de Fomento al lugar (26 de febrero de 1938).

En junio la prensa daba cuenta de la entrevista del ingeniero Zanghellini con dicho secretario de estado, a quien había informado acerca del estado de los trabajos a su cargo:

Se ha terminado satisfactoriamente gran parte del campamento, dotándolo de luz eléctrica, aserradero, maestranza, muelle para el embarque $y$ desembarque, etc.

Trabajan activamente ciento cincuenta obreros en las excavaciones preliminares del canal.

Se cree que las obras se terminarán en unos dos años, daba la forma intensiva en que se trabaja. En breve se aumentará el número de los trabajadores.

Se ha terminado el ferrocarril Decauville para utilizarlo en el arrastre del material de las excavaciones.

Se ha adquirido un barco de la Compañia Naviera de Chiloé para el acarreo rápido, dentro de la zona de todo el material de trabajo.

Se ha confeccionado el plan para la construcción del Hotel de Turismo en la laguna de San Rafael, frente al Ventisquero del mismo nombre, el que tendrá capacidad para cincuenta pasajeros. Su costo es de 350 mil pesos ${ }^{59}$.

A partir de entonces la información sobre la materia prácticamente se interrumpe, por lo que para saber acerca del curso de los trabajos del canal propiamente tal y valorarlos en consecuencia ha de

59 El Magallanes, 11 de junio de 1938. El hotel que se menciona era una obra complementaria de los trabajos de apertura del istmo decidida por el gobierno para poner en valor turístico y por tanto en ulterior explotación a la atractiva zona de la laguna de San Rafael y su glaciar homónimo. recurrirse a los escasos testimonios que han podido compulsarse.

El primero de ellos lo entrega Augusto Grosse, el afamado explorador de las tierras patagónicas centrales, quien llegó al área de Ofqui durante septiembre de 1938. He aquí su relación:

Partimos hacia el Istmo de Ofqui. Se trata de un gran brazo de tierra que une la península con el continente. Este istmo está a unas 130 millas al sur de Aysén. El Ministerio de Obras Públicas ha ordenado abrirlo. Con el barco en que vinimos se trasladan periódicamente los materiales, maquinarias y elementos necesarios para desarrollar el proyecto y se provee de alimentos a los empleados y obreros encargados de esta faena.

Se requiere mucho cuidado en el llamado Río de los Témpanos, desagüe del lago S. Rafael, inmensos témpanos impiden el paso; a pesar de la penumbra reinante, el capitán Jansen, buen conocedor de estos parajes, conduce su barco con pericia a la meta.

Desde el momento que entramos a la laguna, podemos ver a la distancia las luces del campamento, a pesar de la lluvia y el oleaje encontramos el lugar apropiado para anclar, pero ya no se puede pensar en descargar.

Desgraciadamente, a la mañana siguiente, se desencadena una tormenta que lanza los témpanos de norte a sur y hace peligrar al barco. El capitán decide buscar un lugar más seguro.

Debemos esperar otro día y otra noche hasta que por fin podemos bajar a tierra. Voy a saludar de inmediato al señor Engelberto Zanghellini, chileno de ascendencia alemana, que me recibe cordialmente, ya nos habíamos conocido antes, de modo que nuestras relaciones no pueden ser más amistosas.

Una vez que me he preocupado de ubicar a mi gente, me muestran la obra. Me asombra la magnitud de la empresa. Cerca de 200 hombres están ocupados en abrir el istmo.

En medio de esta soledad, el campamento parece una población moderna con sus edificios de administración, talleres, pulpería, bodegas y el conjunto de empleados y obreros. Desgraciadamente, los complejos habitacionales están construídos sobre terreno pantanoso y con las lluvias permanentes, esto no deja de ser desagradable.

Don Ángel, como le dicen los empleados al 
señor Zanghellini, me muestra luego la obra misma, un Canal de Panamá en miniatura, todavía no se ve mucho de él. Por de pronto, están cortando la selva virgen en un ancho de unos 100 metros a través del istmo. Cuya extensión total es de 1.800 metros; lo que se proyecta aqui es un canal que deberá unir la Laguna San Rafael, a nivel del mar, con el Río Negro, que fluye al Golfo de Penas.

El propósito del canal es dar opción a los barcos más chicos que se dirigen hacia Magallanes de tener aquí una vía más corta y segura que la tormentosa vuelta alrededor de la península de Taitao.

Aunque el propósito es bueno, antes de que ese canal esté en condiciones de ser navegado, habría que preguntar si los beneficios que se esperan tienen relación con los gastos que la gigantesca obra requiere...

Hay que hacer navegable el Río Negro en una extensión de 20 kilómetros. El curso superior de este río está lleno de árboles caídos y uno de sus afluentes arrastra una enorme cantidad de sedimentos proveniente del glaciar. También hay que tomar en cuenta la necesidad de instalar una excelente iluminación a lo largo de todo su trayecto, pues abundan las partes estrechas, profundas y rocosas. Seguramente, los témpanos obstruirán a menudo el flujo del lago.

Paralelamente a la construcción del canal se proyecta la de un hotel a orillas de la Laguna San Rafael, que desde un punto de vista turístico parece una buena idea. También esta obra está encargada al señor Zanghellini, y como aún no ha encontrado la ubicación más adecuada, me pide acompañarlo en un recorrido a bordo del barco para estudiar las mejores posibilidades. Accedo con agrado a su petición que me permitirá, además contemplar tranquilamente la belleza de la Laguna, en que afloran miles de témpanos y en cuyas aguas el hermoso glaciar deja caer sus masas de hielo flotante 60 .

El segundo testimonio lo da el contraalmirante Carlos Chubretovich Álvarez, quien siendo guardiamarina integraba en 1939 la dotación del BMS Araucano, de la Armada Nacional, nave en

60 Visión histórica y colonización de la Patagonia Occidental. Expediciones y colonización del explorador Juan Augusto Grosse I., obra patrocinada por el Ministerio de Obras Públicas (Santiago, 1984) , pp. 100-101. la que en diciembre de ese año viajó a Magallanes el Presidente Pedro Aguirre Cerda.

Después de los dos días que le dedicó a su visita a ambas ciudades [Puerto Aysén y Coyhaique] y a alguna de sus áreas adyacentes, el presidente retornó al BMS ARAUCANO para continuar su gira. En esta oportunidad se siguió por los canales que nos llevaron hasta puerto Traiguén, Al día siguiente, temprano, el RAM GALVARINO, que acompañaba al BMS ARAUCANO desde puerto Chacabuco, nos acercó a la desembocadura del río Témpanos, donde abordamos una embarcación motorizada del BMA ARAUCANO en la que lo remontamos para alcanzar hasta laguna San Rafael y visitar el istmo de Ofqui.

No me parce necesario referirme a la belleza del ventisquero y de la laguna San Rafael, que teníamos a la vista, pero si apropiado dedicarle unas lineas a lo que puede apreciar del istmo de Ofqui. Alli encontramos al grupo de obreros que trabajaba con palas y carritos de línea Decauville, procurando retirar miles de tonelada de lodo para tratar de darle forma a un canalizo de uno 2.500 metros de longitud y 2 a 3 metros de ancho, que podría completar la vía acuática interior para unirse la laguna San Rafael con el golfo de Penas, si es que llegaba a conectarse con el curso de varios ríos existentes. Mi interés por saber más del istmo de Ofqui y de sus posibilidades de ser abierto para darle paso por canales a la navegación entre Chiloé y el golfo de Penas, venía desde muchos años antes, cuando mi padre me relataba sus experiencias en esa zona, hacia 1905, siendo guardiamarina de $1^{a}$ abordo de la cañonera Pilcomayo, buque que bajo el mando del comandante García Huidobro efectuaba trabajos hidrográficos en la península de Taitao, entre los cuales se consideraba a posibilidad de abrirse ese istmo. Durante la visita al lugar pude apreciar, junto a mis compañeros, que con los elementos de trabajo que estaban disponibles, la consistencia fangosa del material que se pretendía retirar, la faena empezada sería de una duración que jamás terminaría. Por las respuestas que entregaba el jefe de la obra a las preguntas que se le formularon, llegué al convencimiento que nadie había tomado conciencia de la magnitud de la empresa iniciada, mucho menos de su costo ${ }^{61}$.

61 Recuerdos de mi bitácora (edición del autor, Viña del Mar, 2012), pp. 54-55. 


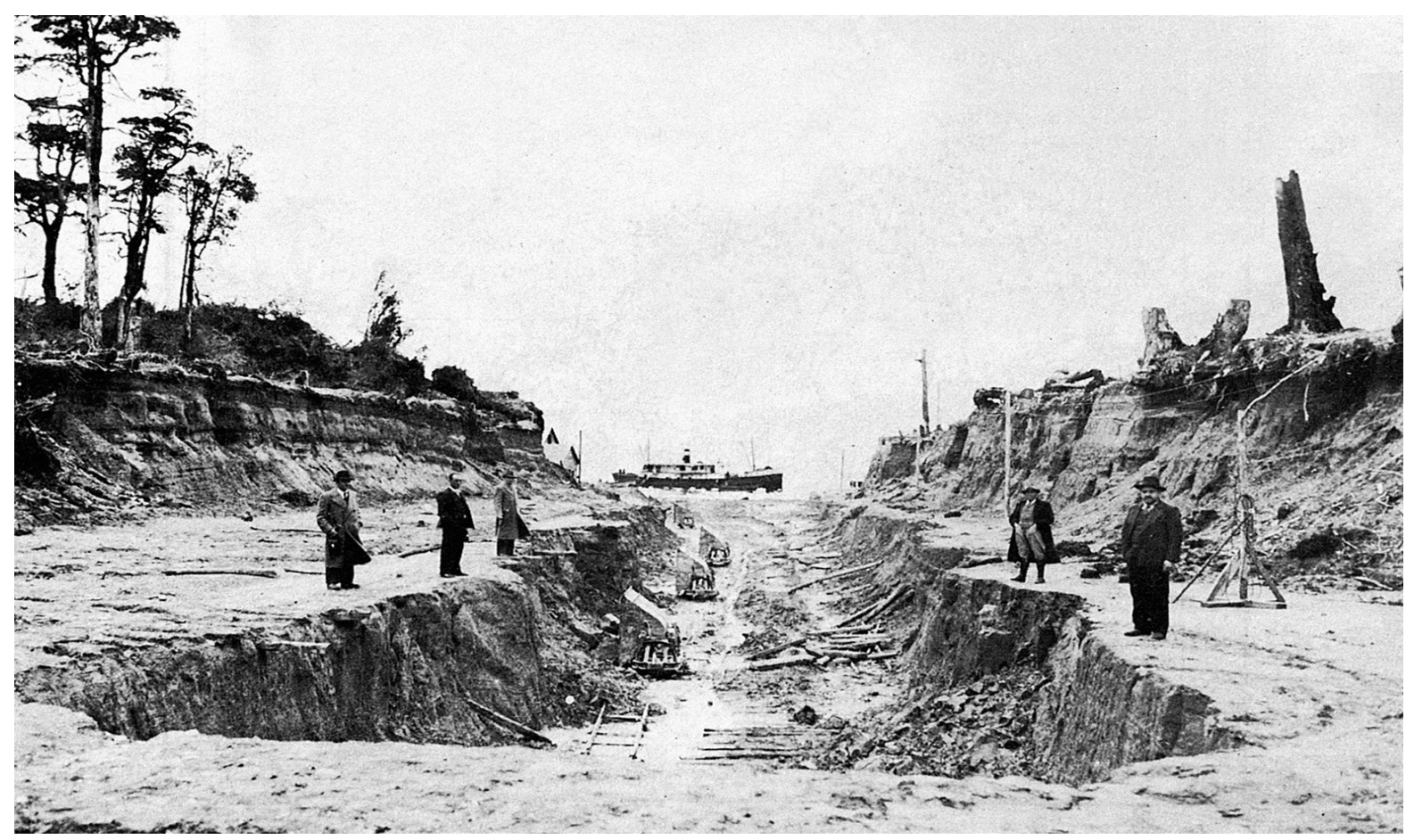

Fig. 2 Boca del canal hacía el norte, que muestra el estado de los trabajos hacia 1941.

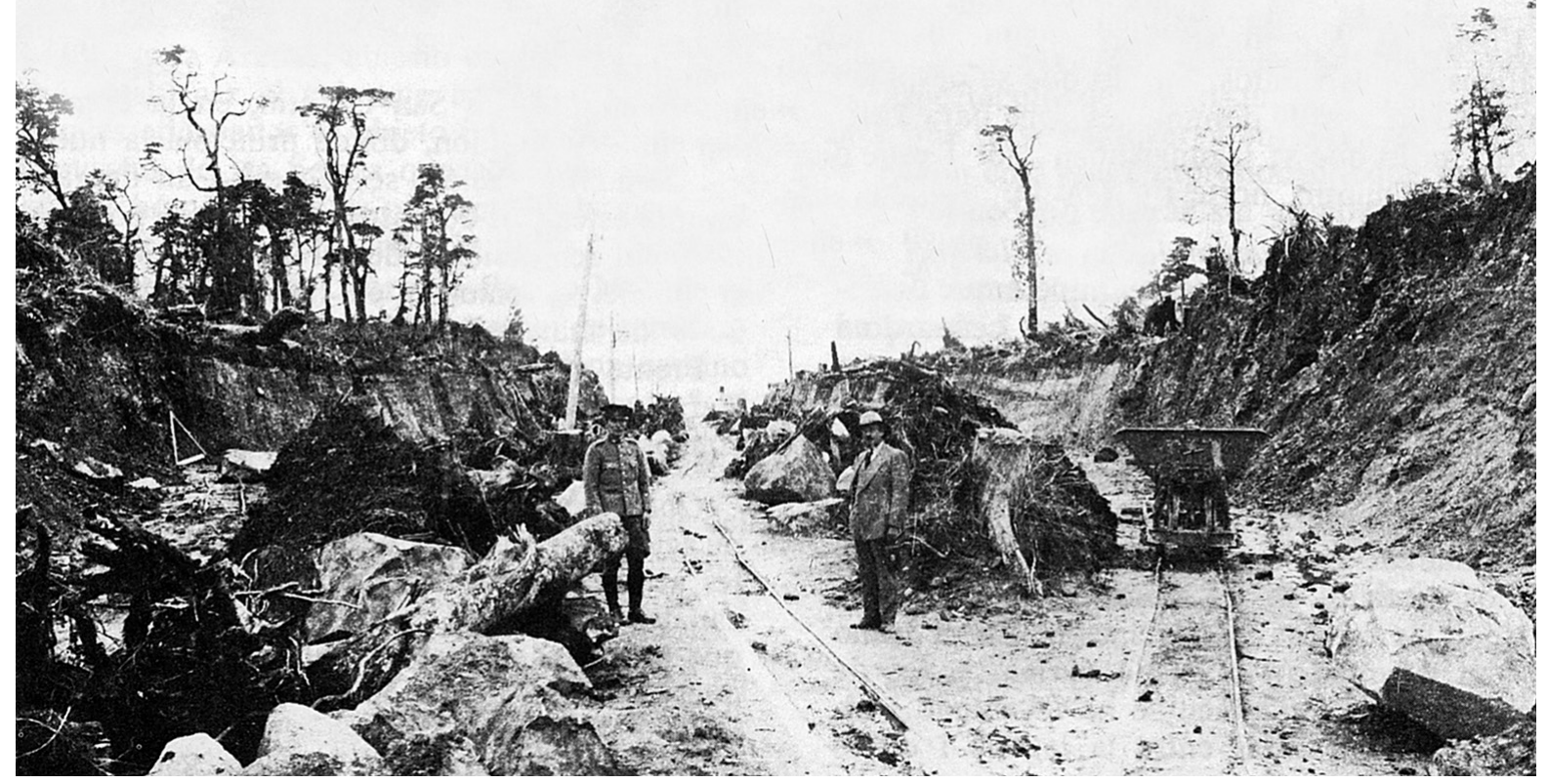

Fig. 3 Otra vista del estado de los trabajos de apertura del canal de Ofqui (1941). 
La tercera y última referencia encontrada procede de la revista En Viaje, publicada en la época por la Empresa de Ferrocarriles del Estado para contribuir a la difusión del turismo en el país. La crónica correspondiente es breve pero precisa en antecedentes:

El proyecto que se está llevando a cabo (1941), consiste en la apertura de un canal de forma trapecial, que tendrá dos mil trescientos metros de longitud y 17 metros de ancho y con una profundidad de 5 metros. Con marea alta el ancho del canal es de 20 metros. El costo de la obra se ha previsto en 6 millones de pesos. Hasta la fecha se han invertido en las obras del canal y en la construcción del Hotel Laguna San Rafael, cerca de 4 millones de pesos. El campamento consta de casas para empleados, para obreros, bodega, maestranza, dispensario, retén de Carabineros, caminos de acceso a campamentos faenas, muelle de desembarco, planta de luz eléctrica, etc.

El hotel Laguna San Rafael está totalmente terminado, faltando solo la instalación de radiadores y caldera para la calefacción. Su capacidad es para 40 pasajeros. Se encuentra situado a la orilla de la laguna de su nombre, frente al ventisquero a una distancia de más o menos 1.000 metros de él.

El Servicio Marítimo de la Empresa de los Ferrocarriles del Estado tiene establecidos viajes directos de Puerto Montt a Ofqui, y barcos perfectamente cómodos, que demoran dos días en hacer el recorrido ${ }^{62}$.

Los trabajos de Ofqui despertaron interés en el país y motivaron algunas visitas a una zona que entonces no era fácilmente accesible. Entre ellas deben mencionarse la que hiciera en 1940 el escritor Benjamín Subercaseaux, cuando recorría el país preparando su afamado libro Chile o una loca geografía, y la practicada por una delegación de la Academia de Guerra que visitó el lugar en 1941 para imponerse de visu sobre las obras y aquilatar mejor su proyecciones (figs. 2 y 3 ).

$\mathrm{Y}$ con este dato se agotan las referencias conocidas a la interesante obra de que se trata. Después el silencio y luego, pasados varios años, hasta mayo de 1943, cuando se supo de la interrupción de los trabajos. ¿Qué había ocurrido? ¿Se habían

62 En Viaje, octubre de 1941, artículo titulado "El Istmo de Ofqui y la laguna de San Rafael". Bajado de Internet. agotado los fondos disponibles? ¿Habían surgido, quizá, dudas insuperables sobre la utilidad de la inversión pública y sobre las ventajas atribuidas al proyecto? Como hubiera sido, la obra se paralizó y se reafirmó que la causa había estado en la pérdida de la pala excavadora adquirida especialmente para mecanizar los trabajos correspondientes, siniestro debido, al parecer, a una mala estiba en el barco que la transportaba. Lo cierto es que un buen día se recibió la orden de paralizar, desahuciar a la gente que allí trabajaba, devolverla a Puerto Montt sin saberse si habría retorno alguna vez. ¿Qué razones, otra vez, se habían tenido a la vista para proceder de esa manera?

Hoy nos encontramos ante la sorpresa de que iniciadas las obras hace pocos años, han sido abandonadas, después de invertirse varios millones de pesos, comentó El Magallanes con ocasión de la visita a Punta Arenas del Presidente Juan Antonio Ríos en febrero de 1944. Errores fundamentales y desaliento por no contarse con adecuados y modernos elementos de trabajo que llevaron a esta resolución que deber revocarse sin demora.

Mucho se alabó en su tiempo esta grandiosa obra de ingeniería, haciéndose los más encomiásticos comentarios, y es por esto que menos se comprende aún cómo se llegó a una decisión contraria tan rápidamente.

[...]Esperamos que la visita realizada por el Excmo. Señor Ríos a la zona de Ofqui, lo habrá llevado al convencimiento de que es patriótico proseguir estos trabajos a la brevedad posible $e^{6364}$.

La escasez de noticias impide conocer cuál fue el curso de los acontecimientos con posterioridad a la visita presidencial a Magallanes (y al parecer también a Ofqui), pero está claro que no hubo mayor prisa en ocuparse del asunto como que recién en octubre de 1944 se anunció la designación de una comisión especial cuya misión era la de informarse sobre el estado en que habían quedado los

63 El Magallanes, edición extraordinaria de fecha 15 de febrero de 1944

64 De los 2.200 metros lineales de corte programados para el canal, con un volumen de material a extraer estimado en $360.000 \mathrm{~m} 3$, al tiempo de la suspensión de los trabajos se había alcanzado a excavar 800 metros lineales, con un total de $153.000 \mathrm{~m} 3$ de material extraído. El costo estimado de lo invertido hasta entonces en la obra fue de $\$ 6.500 .000$ (la construcción del hotel de turismo significó una inversión de $\$ 4.000 .000$ adicionales). 
trabajos en Ofqui, y en consecuencia formular al Poder Ejecutivo las sugerencias o recomendaciones que permitieran resolver definitivamente sobre el controvertido asunto. La comisión se integró con el ingeniero Gabriel Quiroz, jefe del Departamento de Ferrocarriles de la Dirección de Obras Públicas, quién además tenía alguna experiencia de terreno en la materia, que debía presidirla, por el ingeniero Raúl Martín, jefe del Departamento de Puertos del mismo organismo mencionado y por el capitán de navío Julio Santibáñez Escobar, obviamente en representación de la Armada Nacional.

No obstante lo perentorio del plazo asignado para su cometido (treinta días), lo cierto es que en febrero de 1945 nada se sabía en concreto sobre sus resultados, aunque se esperaba que las recomendaciones estuvieran especialmente referidas al empleo de maquinaria de buen rendimiento como para que la obra suspendida, de ser reanudada, avanzara en forma. Así lo sugerían las declaraciones hechas al diario El Magallanes por el senador Alfonso Bórquez al ser entrevistado acerca de su opinión respecto de diversas materias de interés regional ${ }^{65}$.

Pero no había que hacerse ilusiones respecto de la continuidad de las obras, si no más bien debía esperarse lo contrario habida cuenta de la excesiva demora del informe y de los rumores que trascendieron sobre las opiniones expuestas en el seno de la comisión. De hecho la demora reactualizó el tema en la prensa durante los primeros meses de 1945. La lectura cuidadosa -entre líneas-de los comentarios que tal situación generó permite ver que la misma era una consecuencia de una suerte de "guerra de zapa" por parte de quienes se habían opuesto y se oponían al proyecto del canal de Ofqui, operación vigente desde el tiempo en que se había conocido la decisión oficial de llevar adelante la obra y que parecía haber cobrado bríos precisamente cuando se insistía en que debía adoptarse una decisión definitiva sobre el asunto. Esta interpretación, lejos de ser antojadiza, surge de la lectura del editorial de El Mercurio de Santiago del 14 de febrero que entre otras afirmaciones atribuye la paralización de los trabajos a una fatal obstinación, preocupación reiterada en otro comentario de la especie tres días después y vuelta a tratar con particular agudeza en el editorial del 8 de marzo siguiente, al afirmarse que [...] los ingenieros ingleses y norteamericanos 65 El Magallanes, 16 de febrero de 1945. que han resuelto problemas algo más difíciles que la apertura de un modestísimo canal, perecerían de risa si supieran que las autoridades chilenas se han detenido ante dificultades que no son tales, asustadas como niños con fantasmas creados por la imaginación ${ }^{66}$.

Era cierto, pues una de las formas de desacreditar el proyecto había sido y era la de exagerar sus desventajas, como lo recordaría en propio editorial El Magallanes, días después al expresar: Aunque se nos tilde de majaderos, recordaremos al lector algunas de las principales objeciones planteadas por los enemigos del Canal: a) una draga de equis dimensiones, deberá permanecer constantemente limpiando el canal, con un permanente gasto muy alzado; b) en las excavaciones para ejecutar la obra se encontró fondo rocoso; c) enormes témpanos amenazarán constantemente la navegación y aún obstruirán el canal; d) el inmenso ventisquero que hay en la Laguna San Rafael, al avanzar (en circunstancias de que retrocede) sería un peligro para el canal; e) el costo de la apertura del istmo de Ofqui sobrepasaría los cien millones de pesos: f) la nueva vía de navegación serviría solamente para transportar algunos sacos de papas: a enorme costo, entre Chiloé y Magallanes. Además de estas, se han hecho muchas otras afirmaciones antojadizas, tendientes a crear una atmósfera de pesimismo para que se abandone definitivamente el proyecto ${ }^{67}$.

Para el diario puntarenense era evidente la intencionalidad de querer confundir para desalentar a quienes apoyaban el proyecto y desacreditar de paso su propuesta: [...] A juzgar por lo que dice [uno de los ingenieros integrantes] parece que en esa Comisión domina la misma confusión que ha existido en las esferas ministeriales y en otros círculos, confusión que ha sido mañosamente creada para desalentar al Gobierno y conseguir que se abandone el proyecto definitivamente. Y, en ese caso, se trata de un enredo sin solución, que no admite aclaraciones ni la exposición verdadera de los hechos. Por eso habla ese ingeniero de que "el informe dejará sentado que será preferible la construcción de un canal solamente para embarcaciones menores", cuando precisamente es eso lo

66 Referencia respectivas en El Magallanes de 14 y 17 de febrero y 8 de marzo de 1945

67 Edición del 20 de marzo de 1945. 
único que se ha estado haciendo y, si la comisión ha visitado realmente la zona de Ofqui no ha podido ver otra cosa en los trabajos efectuados ${ }^{68}$.

Finalmente el esperado informe pudo llegar a manos del Presidente Ríos. Este mandatario, por entonces seriamente enfermo, aceptó sin embargo reunirse con los miembros de la comisión. Veamos lo esencial de esa entrevista según lo informado por la prensa, en el caso por El Mercurio de Santiago al dar cuenta de una entrevista hecha a Gustavo Lira, Ministro de Obras Públicas y Vías de Comunicación (denominación modernizada del antiguo Ministerio de Fomento):

La Comisión, después de estudiar todos los antecedentes acumulados sobre la materia y de haber hecho investigaciones técnicas en el terreno mismo ha llegado a la conclusión de que para que esta vía nueva de navegación tenga valor apreciable, es necesario construir un canal con profundidad de cinco metros y ancho de 25 metros, más o menos, de modo que sea capaz de permitir la navegación de barcos de mil toneladas en toda su extensión.

La obra así proyectada demandaría una inversión global de ochenta millones de pesos, cifra en la cual quedarian comprendidos los dragados de ríos, la protección contra los témpanos flotantes, el despeje de la vía en todos el recorrido, etc.

Como esta suma es muy elevada, la Comisión propone que, si se desea realizar la obra desde luego, se comience por partes, construyendo un canal que haga posible el tráfico de embarcaciones menores, destinadas a la pesca, caza y transporte costero. Este trabajo se financiaría con unos seis millones de pesos y tendría la enorme ventaja de que serviría para experimentar y despejar al mismo tiempo algunos puntos hasta ahora oscuros.

Construido ese canal, se vería que interés demuestran los habitantes de la zona por utilizarlo y cuales serian sus ventajas positivas. Asimismo se vería si embarcaciones de regulares dimensiones esperarian las mareas para hacer el tráfico fluvial en forma regular.

Posteriormente, el Gobierno podría resolver en definitiva acerca de la construcción de la obra grande, que permitirá la navegación a buques grandes por aguas tranquilas ${ }^{69}$.

68 Edición del 20 de marzo de 1945.

69 Reproducido por El Magallanes de fecha 24 de mayo de 1945.
Mientras se aguardaba la resolución superior, el senador Alfonso Bórquez estimó conveniente entregar un respaldo significativo para el sector de la opinión pública que favorecía la continuación de los trabajos de apertura del canal de Ofqui y, de paso presionar así al Ejecutivo en su terminación. Lo hizo presentando un proyecto en ese sentido en el Senado, moción en la que fue acompañado por los otros senadores de la IX Circunscripción (Provincias de Valdivia a Magallanes): José Maza, Salvador Allende, Alfredo Duhalde y Carlos Haverbeck, además de Miguel Cruchaga Tocornal que quiso adherirse a la misma. Su novedad estuvo en la propuesta de financiamiento que hacía, esto es, la de utilizar los fondos acumulados por las Cajas de Previsión, y ello en vista de la escasez de las arcas fiscales para el cumplimiento del proyecto ${ }^{70}$.

Ello sirvió para reactualizar periodísticamente el asunto $^{71}$, pero de allí no se pasó. El proyecto de Bórquez enfrentaría tropiezos en su curso y acabaría durmiendo en los archivos del Senado. Entretanto la decisión presidencial se demoraba en la medida que otras prioridades y obligaciones llenaban la agenda del presidente, cuya salud se agravaría al llegar 1946 alejándolo de sus elevadas funciones, a las que no retornaría pues falleció a los pocos meses. Esa lamentable coyuntura impuso de suyo otras prioridades políticas y gubernativas exigidas por las nuevas circunstancias. El Poder Ejecutivo dilataría sine die su resolución... y el proyecto acabaría olvidado poco a poco.

El gesto senatorial había sido el canto del cisne para una iniciativa signada desde un principio por las contrariedades que abreviaron su vigencia.

\section{AL FIN SOLO UNA QUIMERA}

Razones de la paralización de la construcción del canal

Cuando se reflexiona sobre lo ocurrido con las obras civiles en Ofqui con la perspectiva de casi tres cuartos de siglo transcurridos desde su paralización definitiva en el contexto de la historia

70 El Magallanes, edición del 5 de septiembre de 1945.

71 El Magallanes en sus ediciones del segundo semestre de 1945 contiene 23 menciones a la materia (noticias del cable, artículos y editoriales), que totalizaron 32 para el año completo. 
de la iniciativa, bien puede decirse de ello, parafraseando un conocido título literario, que ha sido "la crónica de una muerte anunciada". En efecto, desde que el Ministerio de Fomento anunciara en 1935 la decisión de construir el canal a través del istmo de Ofqui pese a la opinión adversa, aunque minoritaria, de la Armada de Chile, no era necesaria una mayor penetración para advertir que el asunto no tenía un comienzo auspicioso y menos un futuro claro.

Parecía contradictorio y hasta curioso que la institución en cuyo seno se había originado la iniciativa unas cuatro décadas antes y que la había patrocinado y sostenido durante ese extenso lapso no obstante las dudas razonables de carácter técnico náutico que surgieron en su transcurso respecto de su factibilidad, se hiciera finalmente a un lado tal vez cuando más se requería de ese importante apoyo, como fue el momento en que oficialmente se adoptó por el Supremo Gobierno la decisión de construir esa obra de ingeniería naval.

Sus motivos, interesan recordarlo, se fundan en las dudas nunca satisfactoriamente despejadas acerca de lo que podía ocurrir con el régimen de mareas una vez que se intercomunicaran las aguas del norte y del sur del istmo de Ofqui, y de cómo tal circunstancia habría de influir prácticamente en la navegación del canal. También las había sobre la climatología del área, el régimen de precipitaciones y su influjo en la masa y dinámica de los cuerpos glaciares andinos -el de San Rafael especialmentecuyas consecuencias podían afectar la navegabilidad de la laguna homónima, parte del sistema operativo del canal proyectado. Igualmente había sido materia de preocupación lo concerniente al dragado que debería realizarse en ciertos tramos de la zona involucrada en el proyecto y el despeje de árboles muertos y troncos, todo ello para mantener en condiciones seguras de navegación el canal y sus accesos.

A estas dudas de carácter técnico náutico se había asociado desde largo tiempo atrás el convencimiento entre jefes y oficiales acerca de la irrelevancia de la economía de tiempo en la navegación norte-sur y vice-versa por la ruta interior que se proponía, al comparar la diferencia de longitud del trayecto tradicional rodeando la costa exterior de la península de Taitao, con el correspondiente al proyecto (137 millas), economía que podría esfumarse tan sólo por la espera de tiempo favorable para el cruce del canal. No menos importante había sido la certidum- bre respecto del elevado, quizás altísimo costo de ejecución de la obra de ingeniería hidráulica que era el canal según se lo había proyectado originalmente por Emilio De Vidts. Las mencionadas dudas y con seguridad otras de diferente entidad, acabaron por generar una honda sensación de incertidumbre en el alto mando naval durante el lapso 1931-35, respecto de la factibilidad de la obra según se la había proyectado y aun tocante a su conveniencia para el país en la alternativa del mejoramiento de las comunicaciones marítimas y, en general, con la mayor y más eficiente vinculación del territorio metropolitano del país con la región patagónica occidental, en la forma de un servicio subvencionado bien concebido. Las mismas acabaron manifestándose en la posición de minoría del almirante Olegario Reyes del Río en el seno de la comisión de marras. De esa manera la Armada de Chile se marginó del proyecto oficial.

Este, entonces, si bien prosiguió según se conoce, lo hizo evidentemente debilitado en su crédito público al tratarse de una obra de magnitud menor a la originalmente conocida que -visto lo acontecido posteriormente- asumiría más el carácter de un canal "experimental" para comprobar su operatividad técnica y económica, que el de una obra menor del género aceptada a priori como de utilidad pública. Quizás en esta materia lo peor que puede acontecer es partir con un trabajo de gran envergadura pero con un convencimiento insuficiente sobre sus ventajas esperadas, amén de los costos financieros y del tiempo demandado por la construcción que lo hagan finalmente conveniente.

$Y$ fue en este aspecto donde tempranamente, mientras se avanzaba en la obra, que quedaron a la vista sus debilidades a juzgar por la opinión de visitantes contemporáneos según se ha dado a conocer.

Hubo en todo el asunto, más en su fase de preparación final, debe reconocerse, una fuerte carga de voluntarismo entre quienes propiciaron el proyecto -cuya buena fe no debe cuestionarse-, sostenida por el autoconvencimiento y recíproco influjo nutrido por una serie de mitos, como los referidos al desarrollo del comercio entre Chiloé y Magallanes y su beneficio para el abaratamiento del costo de la vida en la provincia austral; el de la riqueza inconmensurable del territorio patagónico occidental y el de la colonización y poblamiento de sus vastos distritos despoblados e inexplotados. 
Tocante al primer aspecto, la realidad indesmentible del movimiento marítimo conocido para mediados de los años de 1930 era que entre junio de 1934 y el mismo mes de 1935 solo se movilizaron 3.500 toneladas (principalmente papas) entre Chiloé y Magallanes y 320 en sentido inverso, sin que hubiera a la vista una potencialidad real de incrementar substancialmente este comercio, según lo demostró el estudio elaborado por el Rotary Club de Punta Arenas. Por otra parte, el tráfico esperado de embarcaciones menores por la ruta del canal proyectado tampoco reduciría los fletes marítimos, con lo que sus beneficios para el abaratamiento de la vida -gran baza propagandística del proyectohabrían de ser igualmente nulos.

De alli que quien apreciara objetivamente las cosas debía desechar cualquier ilusión sin fundamento y convenir en que La enunciación de estos rubros demuestra con claridad que la base económica de esta obra no justifica la inversión de grandes capitales, ni tampoco justifica la infima parte de utilidad que para esta región [Magallanes] significaría, según lo habían expresado los autores del informe de la entidad rotaria citada ${ }^{72}$.

Lo de la "riqueza inconmensurable" de la Patagonia occidental en especial la que se atribuía a los sectores poco o nada conocidos, era cosa que únicamente estudios bien llevados y exploraciones debidamente realizadas, ambos de prolongado curso y costo no menor, debían poner en evidencia en el porvenir $y$, por entonces, a que ello no pasaba de ser una mera ilusión ${ }^{73}$.

Otro tanto podría decirse respecto del poblamiento y colonización de amplios sectores geográficos de ese gran territorio, esto es, una utopía desde que el esfuerzo exploratorio pionero en tal sentido, realizado entre fines del siglo XIX y las primeras décadas del XX, había demostrado lo difícil que podía llegar a resultar habida cuenta de lo salvaje de su naturaleza y del colosal esfuerzo que

72 El Magallanes, edición del 23 de julio de 1935 citada.

73 Vale para el caso conocer lo que sobre este particular años después se escribiría en la Geografía Económica de Chile, importante obra patrocinada y publicada por la Corporación de Fomento de la Producción (Santiago, 1960): [...] queda por recalcar el carácter más importante de la Patagonia, el de ser una región nueva, una región por definirse, que continua siendo el gran horizonte pionero y la más promisoria y e incalculable potencialidad económica futura encarnada por una región chilena (tomo IV, p. 419). implicaba en tal respecto. En buenas cuentas, el disminuido proyecto del canal en el istmo de Ofqui había tenido fundamentos muy frágiles, por decir lo menos.

Por si faltara, los trabajos se realizaron a base del esfuerzo humano (prácticamente a pico y a pala), que siendo por lejos mejores y más dignos que la faena forzada de los presidiarios según se pensara otrora, resultó penoso y frustrante por falta de maquinarias apropiadas, deviniendo paulatinamente una realidad agobiante para el ánimo de ingenieros y técnicos a cargo y, al fin, para todos los que se hallaban involucrados en la obra. No eran esos (fines de los años 30 y principios de los 40) los tiempos que los chilenos de posteriores generaciones conocerían en materia de obras públicas, con despliegue y utilización impresionante y eficiente de recursos tecnológicos. En esas condiciones, como bien observaron algunos testigos, la obra de apertura del istmo de Ofqui no tendría un satisfactorio término.

Concluyendo a la luz de lo relatado, se planteó una obra de ingeniería de gran magnitud sin conocerse a fondo todas sus complejas exigencias y se inició su construcción sin disponerse de todos los recursos que la modernidad tecnológica requería y ofrecía. He ahí, a nuestro juicio, las razones de su fracaso ${ }^{74,75}$.

\section{Opiniones posteriores sobre lo ocurrido}

74

Nos preguntamos si para la elaboración del proyecto finalmente intentado se tomó en cuenta la experiencia histórica mundial en obras del género; y más que en las grandes y afamadas (Suez, Kiel, Panamá), en otras menores de exitoso uso como era el caso del canal de Corinto, en Grecia, que corta el istmo que une la famosa península del Peloponeso con la masa continental europea, para unir las aguas de los golfos de Corinto y Egina y de ese modo intercomunicar los mares Jónico y de Creta en el Mediterráneo oriental. No deja de ser curiosa la similitud que se da tanto en la longitud de los istmos como en las formas y dimensiones de las penínsulas del Peloponeso y de Taitao.

75 El hotel, de algún modo asociado a la obra del canal, aunque se terminó no tuvo mejor destino pues acabó abandonado y destruido. Sirva para entenderlo el juicio de Benjamín Subercaseaux quien habiéndolo visto en construcción en 1940, volvió a verlo dieciséis años después y sobre su estado escribió: Los loberos entran ahí y roban artefactos, maderas y trozan para leña los pisos de parquet. Es una fábrica inmensa donde los vientos se cuelan por los vidrios quebrados, golpeando puertas y ventanas. ¡Nunca vi algo más absurdo y criminal! (Op. cit., edición de 1973, p. 231). 
Según parece no abundan las opiniones acerca del fallido intento de apertura del istmo de Ofqui en la inmediata posterioridad a los hechos. Por ello interesa conocer lo que se escribiera después sobre la materia en obras relativamente contemporáneas.

La primera y más próxima al tiempo de que se trata proviene del geógrafo Carlos Keller quien refiriéndose a la obra cuando todavía podía esperarse su reanudación, 1949, señaló:

Como es sabido, se ha iniciado la construcción de un canal entre la laguna de San Rafael y el río Negro, ideado para pequeñas embarcaciones, incluso goletas. La construcción de ese canal no representa un problema técnico o financiero, pues el largo del canal sería de solo 2,2 kms., y el terreno que atraviesa no ofrece dificultades.

Las dificultades del canal, si se le quisiera ampliar, para que puedan pasar naves de gran tonelaje, comenzarian en los ríos Negro y San Tadeo, que deberían ser regularizados, lo que es difícil, tanto por las enormes variaciones de su caudal de agua, como por su fondo y orillas cenagosas, que hacen imposible la construcción de obras de arte de calidad sólida, debido a que se hunden con gran facilidad. Se trata de una longitud de $25 \mathrm{kms}$.

Curiosamente, se ha emprendido la construcción de esta obra sin haber estudiado el régimen hidrológico de los ríos que forman el San Tadeo, o sea, el Negro y el Lucac, cuyo conocimiento había quedado completamente ignorado hasta la fecha ${ }^{76}$.

La segunda opinión se encuentra en el excelente libro The Human Geography of Southern Chile, (London, 1957) en el que su autor, el geógrafo Gilbert J. Butland hace la siguiente referencia:

El proyecto de abrir un canal ha sido mantenido por más de cuarenta años y varias comisiones han informado sobre sus posibilidades y costos. Los trabajos comenzaron en 1937 y fueron abandonados cinco años después. Como consecuencia, durante la última década, el canal de Ofqui ha llegado a ser materia de controversia politica y local, particularmente en la provincia de Magallanes. Aunque nadie se opone al proyecto en principio, el punto es el de cuál es su inmediata importancia práctica para el desarrollo de la zona

76 La Región del Hielo Continental de Aysén (Editorial Sociedad Amigos del Libro, Santiago, 1949), pp. 19-20. austral de Chile o si muchos estímulos, más vitales y económicamente menos costosos, no podrían conseguir resultados tanto mejores ${ }^{77}$. Las dificultades de construcción fueron mayores y los costos progresivamente elevados, y dadas las fuertes inversiones que por entonces exigía el programa de industrialización de Chile habrían obligado a postergar la continuación de los trabajos. Aunque el istmo sólo tiene 2.400 yardas de ancho, su apertura incluye la profundización de los ríos San Tadeo y Negro por a lo menos otras seis millas, y además de las excavaciones necesarias deben ser removidos los árboles muertos sumergidos, los troncos y bancos de arena; hay que enfrentar los problemas sobrevinientes por causas de las corrientes y encontrar una manera para evitar que los témpanos procedentes del glaciar San Valentín bloqueen el acceso norte del canal.

Construido en un tamaño suficiente para permitir el paso de barcos de 2.500 toneladas netas, ayudaría indudablemente a la comunicación entre Puerto Montt y Punta Arenas tanto desde el punto vista de la velocidad de las naves como de la comodidad de su pasaje, pero los costos de construcción de un canal de semejante tamaño llegarían a ser prohibitivos en relación con el posible tráfico que podría hacerse por él. Construido en una escala mucho menor como para permitir el paso de pequeñas embarcaciones veleras de menos de 300 toneladas (que es el proyecto que intentó realizarse), podría servir para estimular la ocupación colonizadora, la explotación forestal, la agricultura y la crianza de animales y la pesca disponible en el área, $y$, si llegaran a construirse caminos desde el núcleo oriental de Aysén podrían servir para la salida de su producción. Ciertamente las zonas interiores orientales de la península de Taitao son un "cul-de-sac", como consecuencia del istmo de Ofqui, pero sus potencialidades no parecen ser abundantes. Un canal aún en estos términos modestos tendría un costo de a lo menos un millón de libras esterlinas, y la provincia de Aysén ya está atendida por numerosos pequeños veleros que vinculan los establecimientos de las

77 Valorizamos especialmente este aspecto de la opinión del geógrafo pues la misma es el fruto de su permanencia en Magallanes (fue Director del Colegio Británico) y por tanto pudo conocer de primera mano opiniones de gente antigua de la región respecto del controvertido asunto. 
zonas litorales. No hay ninguna duda que semejante monto utilizado en la preparación del deficiente sistema de caminos sería mucho más beneficioso para la economía regional78.

La tercera opinión compulsada corresponde a la obra ya mencionada de la Corporación de Fomento de la Producción y en la misma únicamente se incluye una breve referencia por la que se lamenta el fracaso de todos los esfuerzos realizados hasta entonces (fines de la década de 1950) para eliminar el obstáculo del istmo de Ofqui ${ }^{79}$, al tratar en particular el punto de la insuficiencia de las comunicaciones marítimas en la región patagónica chilena.

\section{Nostalgias y ecos tardíos del proyecto}

Corrió el tiempo y el asunto se fue olvidando y tan sólo una que otra muy rara mención o algún artículo menor en un diario recordaría el tema de Ofqui. Pero en los años 80 pareció revivir siquiera por breve lapso.

Primero fue en Coyhaique donde un grupo de intelectuales y profesionales que habían dado origen a la revista Trapananda, encabezados por el historiador Baldo Araya Uribe y por el ingeniero Antonio Horvath, buscaron, entre otros aspectos de interés regional, reactualizar el tema publicando el informe del ingeniero De Vidts y algunos comentarios que lo situaban en el contexto de la nueva realidad de desarrollo en que se hallaba por entonces la Región de Aysén y, en general, la Patagonia norte y central chilena. En este aspecto, valorándose los adelantos ocurridos a lo largo del siglo en especial en infraestructura caminera y en comunicaciones, se replanteó el tema de la apertura del istmo de Ofqui como una posible solución integradora de la parte sur de la región ${ }^{80}$. Inclusive, aunque igualmente utópica como la idea original se sugirió la alternativa de otra vía a través de la península de Taitao, cruzando los lagos Presidente Ríos y Elena que incluiría nuevos canales artificiales ${ }^{81}$.

Tres años después el punto fue retomado por la Revista del Domingo de El Mercurio de Santiago (edición del 4 de septiembre de 1983). Entonces

78 Op. cit., pp. 121-122. Traducción libre del autor.

79 Op. cit. tomo IV, p. 441.

80 Artículo de Horacio Balmelli "Actualidad del istmo de Ofqui", Trapananda $\mathrm{N}^{\circ} 3$ (febrero 1979- marzo 1980), p. 88.

81 Artículo "Istmo de Ofqui", sin expresión de autor, id. Id., p. 91 se hizo una brevísima síntesis histórica del asunto, señalándose que se conocían 25 estudios sobre la materia y abundándose en comentarios sobre las dificultades y dudas que había debido enfrentar el fracasado proyecto de 1935-37. El artículo en referencia recogió algunas opiniones lo que bastó para demostrar que la materia siempre generaba controversia. Veamos, asi si el contra-almirante en retiro Carlos Chubretovich afirmó que la navegación por esa zona ya no es una aventura peligrosa, como hace algunas décadas. Ahora existen buques capaces de cruzar el golfo de Penas sin problemas. También hay faros, satélites, instrumentos que entregan las informaciones climáticas a cada momento. El riesgo ya no existe, y no se justifica el canal ${ }^{82}$. En la posición contraria, otro antiguo marino, el capitán de Fragata Horacio Balmelli, ex-Gobernador Marítimo de Aysén, sostuvo entonces: Es cierto que el Golfo de Penas ha dejado de ser un peligro claro. Pero sigue siendo inseguro. Una nave menor no puede arriesgarse pescando en esa zona. Podría quedar encerrada durante días o semanas. Es necesario construir una ruta de navegación por el interior. Incluso por razones de seguridad nacional ${ }^{83}$.

Otros de los consultados, los ingenieros Patricio Ugarte, comercial, y Miguel Ruiz-Tagle, civil, opinaron en conjunto que plantear un canal para naves de gran tonelaje es poco menos que infantil. Nosotros retomamos un estudio que Obras Públicas realizó hace catorce años. Planteamos que la construcción de un canal, la contención de témpanos de la laguna San Rafael y el balizamiento de los ríos costaría sólo dos millones 800 mil dólares ${ }^{84}$.

Distinta fue la opinión de otro ingeniero civil, Antonio Horvath, a la sazón Director Regional de Vialidad y hombre con gran conocimiento de la geografía aysenina, quien afirmó categóricamente: El canal se debe abrir. No hay duda. Sin embargo para iniciar cualquier trabajo se debe tener respuesta a todos los problemas. Y en su calidad de cabeza de una nueva propuesta para recuperar la antigua iniciativa, añadió: Proponemos hacer un canal de penetración para naves de hasta 150 toneladas. La mayor parte de las embarcaciones pesqueras de la zona se encuentran bajo ese peso. Los trabajos aprovecharían lo realizado hace cuarenta años.

82 Revista citada, p. 4.

83 Id., p. 5.

84 Ibid p. 5 
Tendría cinco metros de ancho por tres y medio de alto.

[...] En el canal se deben colocar compuertas a la entrada y salida del canal, es decir en San Rafael y el río Negro. Con esto no se generan corrientes de ningún tipo. Se elimina el problema del impacto físico negativo en la zona. [...] está planeado de acuerdo a las actuales características de los ríos Negro, San Tadeo y el Paso Expedición. Así no existe necesidad de dragas los ríos ni limpiarlos de bosques sumergidos ${ }^{85}$.

Definitivamente ese parecía ser el parecer predominante de los ingenieros por sobre el de los marinos, al revés de lo que había sido antaño. Por eso, con evidente convicción acerca de la certidumbre de lo planteado, Horvath reiteró: No nos cabe duda que este canal tendría un uso práctico inmediato. Podrán atravesar con facilidad naves que deben iniciar la colonización de esa zona. Además, pensamos que es más cuerdo experimentar con unos veinte millones de pesos que arriesgar cuarenta millones de dólares ${ }^{86}$.

Pero ni aun así, esto es, con la acogida que por entonces tenía en la Región de Aysén el dinámico y bien reputado ingeniero en los ambientes público y privado ${ }^{87}$, fue suficiente para reponer en el interés colectivo el tema de Ofqui, como quedó en evidencia con la realización de la III Reunión de Intendentes de las Regiones de Los Lagos, Aysén y Magallanes, (Coihaique 1983) en cuyo temario se consideró la materia concluyéndose que [...] Debía abandonarse dicho proyecto por otros de mayor rentabilidad social y económica comprobada, y factibilidad técnica cierta ${ }^{88}$. Una decisión ciertamente lapidaria para la renovada iniciativa atendido el nivel en que se conoció del asunto.

Con una porfía digna de mejor causa, el año siguiente en el mismo Coyhaique y con ocasión de la realización del tradicional "Mes del Mar", se retomó el tema y nuevamente en medio de controversia como para mantener el sino histórico del asunto,

85 Ibid.

86 El replanteamiento del proyecto, en su versión más reducida todavía, incluyó una expedición a Ofqui con participación de funcionarios del Ministerio de OO.PP. y de la Gobernación Marítima de Aysén y otra gente que adhería a la iniciativa.

87 Horvath fue por su responsabilidad, su visión y decisión, el hombre clave en el notable impulso que por la época tuvo la construcción de la Carretera Austral.

88 Información bajada de Internet. otra vez sin mayor trascendencia.

En 1988 el Instituto de Investigaciones del Patrimonio Territorial de Chile de la Universidad de Santiago, realizó las II Jornadas Territoriales para tratar como gran tema "Chiloé y su influjo en la XI Región", oportunidad en que se presentaron diferentes contribuciones de especialistas sobre tan interesante materia. Entre ellas estuvo un erudito trabajo del académico Hernán Ferrer Fouga, antiguo oficial de marina quien abordó las expediciones marítimas (hidrográficas) realizadas históricamente en la región patagónica central y su importancia para las comunicaciones marítimas de la misma. Pues bien, en su consideración del conocido proyecto del ingeniero de Vidts y sus avatares, concluyó por proponer su propia alternativa en sustitución al fallido proyecto de marras: la de habilitar una doble solución marítimo-vial para franquear el paso de barcazas que haría el trasbordo de carga entre las partes norte y sur del istmo. Su fundamento estaba en que lo que básicamente interesa es el concepto central de la idea propuesta, la cual puede tener numerosas variantes y esta se funda en superar el istmo como obstáculo geográfico por intermedio de una estación de transferencia de carga [su novedad], la cual incluye entre sus puntos terminales norte-sur y viceversa la combinación de medios de transporte marítimo, terrestre y fluvial ${ }^{89}$.

$\mathrm{Al}$ cabo de otro lapso de tres lustros, en enero del 2003 la materia fue tratada por la Comisión Especial de Zonas Extremas de la Cámara de Diputados, oportunidad en que se conocieron los últimos estudios realizados por el Ministerio de OO.PP. para la apertura del istmo de Ofqui. Por fin, como un eco tardío del ruido público que ocasionara la materia al promediar la década de 1930, se ha sabido recientemente de otra iniciativa propuesta por la firma de ingenieros Ghisolfo a la Dirección de Concesiones del Ministerio de Obras Públicas, cuya novedad reside en que la magnitud del canal propuesto es al parecer menor aún que la de los proyectos precedentes, como que se trata sólo de una vía útil para embarcaciones deportivas (yates, gomones, kayaks) y pesqueras ${ }^{90}$. Está visto que la

89 Chiloé y su influjo en la XI Región, II Jornadas Territoriales Instituto de Investigaciones del Patrimonio Territorial de Chile, Universidad de Santiago (Santiago, 1988), pp. 108109.

90 Internet citado. 
reducción progresiva en tamaño y proporciones del canal ha sido una constante en la historia del proyecto.

Debe reconocerse al fin que la iniciativa de abrir el istmo de Ofqui ha demostrado, para la historia, una suerte de vigor imperecedero.

\section{SITUACIÓN COMPARADA DEL POBLAMIENTO Y LAS COMUNICACIONES EN LA PATAGONIA CHILENA A PRINCIPIO Y FINES DEL SIGLO XX}

En este recorrido histórico siguiendo el hilo conductor de un proyecto quimérico cuyos avatares llenan un siglo, viene al caso conocer los cambios que se dieron entre los tiempos iniciales y terminales del extenso lapso, inclusive sus modalidades y circunstancias de evolución, en lo tocante al poblamiento, al desarrollo económico y a las comunicaciones consiguientes a lo largo y ancho del extenso territorio patagónico chileno desde la línea Chacao-Reloncaví hasta el cabo de Hornos.

En el principio del siglo XX en ese espacio geográfico (un tercio del territorio americano de Chile) se contaban tres núcleos importantes de poblamiento con su correspondiente fundamento económico, en desarrollo: la zona continental sur de Llanquihue conformada por el departamento homónimo y los de Calbuco y Maullín, cuyo centro dinámico de vida y actividades administrativas y económicas era Puerto Montt; la zona insular de Chiloé (isla grande y las menores contiguas), cuyos centros eran las pequeñas ciudades de Ancud y Castro; y, mediando un gran vacío, en el extremo austral, el territorio de Magallanes (zona centro-oriental), con cabecera en la pequeña pero ya dinámica Punta Arenas. El centro del territorio continental patagónico permanecía deshabitado e inexplotado económicamente y sólo a partir mediados de la primera década se iniciaría su ocupación.

Tanto la primera como la tercera zona eran todavía "territorios nuevos", abiertos a la colonización desde medio siglo antes y por entonces se hallaban en pleno y pujante desarrollo merced a laboriosidad y creatividad de la inmigración europea (alemanes en Llanquihue, y croatas, españoles, británicos y otros en Magallanes). Chiloé poblado desde tiempo inmemorial por aborígenes (principalmente por huilliches de lejano origen continental), aunque ocupado por los españoles desde fines del siglo XVI había llegado al siglo XX evidenciando un notorio retraso cultural e infradesarrollo económico en comparación con las otras dos zonas, más aún con la vecina Llanquihue. En conjunto la macro región patagónica chilena tenía una población que, de acuerdo con el censo nacional de 1907 redondeaba las 160.000 almas (Cuadro 1). Su economía se basaba fundamentalmente en el aprovechamiento de sus recursos naturales (agricultura, crianzas pecuarias, explotación forestal, pesquería), con un interesante pero todavía incipiente desarrollo artesanal e industrial derivado, en lo referido a la primera gran zona, y de sus pasturas en el extremo austral, recurso que había permitido la introducción de la crianza ovina extensiva en el país, originando de paso una etapa industrial en plena fase de desarrollo.

Tocante a las comunicaciones, esencialmente marítimas por la determinante geografía generatriz de vastos espacios terrestres y marítimos interrelacionados, las mismas desde antiguo se habían desarrollado intensamente al punto de configurar para comienzos del siglo XX un sistema -el del mar interior chilote- que comprendía y vinculaba el ámbito poblado en las islas y litorales continentales. Por esa suerte de Mediterráneo habían circulado y circulaban hombres, productos, ideas y culturas con una fuerte caracterización motivadora e individualizadora. Ese tráfico inicialmente basado en el uso de embarcaciones veleras de pequeño tonelaje (lanchas chilotas), fue incorporando paulatinamente vapores de diferente tamaño con lo que se satisfacía los requerimientos del intenso comercio local y del movimiento de personas. Va de suyo que, además, la región septentrional se vinculaba con Chile metropolitano a través de Puerto Montt, principalmente, de Ancud y en menor medida de Castro. La gravitación que en este aspecto asumió el primer centro pasó a ser incontrarrestable desde fines del siglo XIX cuando la ocupación y apertura del territorio mapuche y construcción de las primeras vías camineras hicieron posible el contacto con las regiones situadas al norte de los río Cautín y Bío Bío. Estas características de preponderancia se afirmarían una vez que el ferrocarril longitudinal sur llegó en 1912 hasta Puerto Montt.

En Magallanes, el paulatino poblamiento de sus diferentes distritos continentales e insulares originó un sistema autónomo de comunicaciones 
marítimas usando de las aguas del Estrecho y sus espacios tributarios (mares interiores, canales) que se extendió paulatinamente a los litorales atlánticos argentinos en la Patagonia y la Tierra del Fuego, y a las islas Falkland. Su propia vinculación con el mundo exterior (Europa, Sudamérica oriental, Argentina, Uruguay, Brasil) y con Chile metropolitano era muy buena, servida como estaba por líneas regulares de vapores de carga y pasajeros desde los años 60 de la centuria precedente, que intercomunicaban por la vía del estrecho de Magallanes a los territorios ultramarinos con el litoral sudoriental del Pacífico.

Las comunicaciones entre la zona septentrional de la macrorregión y la meridional eran escasas y precarias al despuntar el siglo XX, y sólo comenzaron a mejorar tras el establecimiento de un servicio marítimo entre Punta Arenas y el litoral central de Chile, con escalas en Castro y en Puerto Montt, por parte de la empresa armadora magallánica Braun \& Blanchard, a partir de 1907.

La ocupación progresiva del novísimo territorio del Áysen (después Aysén), fase que tomó las primeras cuatro décadas del siglo, fue facilitada en parte por el movimiento que se estableció entre el incipiente Puerto Aysén, por mucho tiempo el único punto de paso entre el territorio interior en plan de colonización y el mundo distante, que unía especialmente a esta localidad portuaria fluvial con Puerto Montt, su principal centro de abastecimiento y de recepción de sus productos, pero también con Castro usando de vapores pequeños y embarcaciones a vela. En la medida que se ocupaba y poblaba Aysén, también lo fue haciendo Chiloé continental con desfase temporal y un notorio menor énfasis, dadas las enormes dificultades que oponía la naturaleza y la escasez de recursos de los colonos y la por lejos insuficiente (y a veces nula) preocupación del gobierno central del país.

Entre Aysén y Magallanes no hubo nunca comunicaciones regulares, no obstante que la jurisdicción del segundo cubriría hasta 1928 entre otros los sectores continentales del lago San Martín (después O־Higgins) y del Baker, y cuando se dieron fueron sólo ocasionales mientras los intereses de capitalistas de Punta Arenas estuvieron referidos a algunos emprendimientos colonizadores (Sociedad Explotadora del Baker, Sociedad Ganadera Posadas, Hobbs y Cía.).

Así descrita en general, se desarrolló la vinculación intrarregional y con el mundo exterior, separada en dos ámbitos norte y austral por la península de Taitao y el golfo de Penas y por su complejo marítimo de canales septentrionales y meridionales, durante el primer tercio del siglo XX. No obstante los adelantos que pudieron constatarse en su transcurso el reclamo de sus poblaciones decía con la modernización de los servicios marítimos (Magallanes), con la construcción de caminos (Aysén, Chiloé continental) y con la salida expedita de sus producciones económicas hacia el mercado nacional y el exterior (Aysén, Magallanes), y con el mejor abastecimiento para la vida de sus habitantes (Magallanes, Chiloé).

Cuando en el contexto de la preocupación del gobierno de Chile por la zona austral al promediar los años de 1930 se discutía sobre la apertura del istmo de Ofqui -tenido como el gran obstáculo geográfico para la integración de la macrorregión patagónica al cuerpo metropolitano de la Republica-, una alternativa propugnada por una parte de la opinión pública y por la Armada Nacional fue la del establecimiento de un servicio marítimo mixto, de pasajeros y carga, dotado de unidades modernas de tonelaje mayor (sobre las 3.000 toneladas brutas), rápidas, cómodas y de costo económico razonable asegurado por una subvención estatal. Con esta alternativa, que no requería de mayor apoyo que el del mejoramiento de la ruta tradicional en condiciones de creciente seguridad y con señalización apropiada, se esperaba satisfacer poco a poco las comunicaciones y el comercio intrarregional, y la integración con el resto de Chile. De esa manera se deseaba superar la falencia atribuida al doble servicio mercantil privado (Braun \& Blanchard, Menéndez Behety), al que reiteradamente se achacaba el monopolio del mismo y, por derivación, su responsabilidad en la carestía de la vida en Magallanes.

Las decisiones del gobierno de Arturo Alessandri en tal sentido, que incluyeron la formación de una flota mercante estatal cuya responsabilidad de gestión se encomendó a la Empresa de Ferrocarriles del Estado, conformada por tres unidades mayores y cinco menores, fueron recibidas con general aplauso por la opinión pública ${ }^{91}$. Con ella se dio

91 Las unidades mayores adquiridas fueron los vapores Alondra (3.445 tons.), Puyehue (3.188 tons.), Villarrica (2.989 tons.); y las menores Moraleda (785 tons.), Tenglo (749 tons.), Taitao (704 tons.), Trinidad (378 tons.) y Chacao (315 tons.). Dato 
Tabla 1 Demografía comparada de la macro región austral 1907-2002.

\begin{tabular}{|l|l|l|l|l|l|}
\hline & 1907 & 1920 & 1960 & 1982 & 2002 \\
\hline Los Lagos* & 144.864 h. & 177.662 h. & 212.031 h. & 541.980 h. & 712.039 h. \\
\hline Aysen & 200 h. & 1.660 h. & 1.660 h. & 37.770 h. & 89.986 h. \\
\hline Magallanes & 17.330 h. & 28.980 h. & 28.980 h. & 73.224 h. & 147.533 h. \\
\hline Macro-Región & 162.394 h. & 208.302 h. & 208.302 h. & 323.025 h. & 949.558 h. \\
\hline
\end{tabular}

*Los Lagos ${ }^{93}$

comienzo al servicio a contar de enero de 1939. La experiencia histórica daría cuenta de lo acontecido con el compromiso asumido por el Estado a favor de la gran región austral con la operación de un servicio mayor (o "Línea Grande") para vincular a Magallanes con el resto del país y viceversa, y un servicio menor (o "Línea Regional") para atender exclusivamente las necesidades de comunicación de la zona Reloncaví- Chiloé- Aysén. En la realidad sólo se cumplió a satisfacción la segunda, pues la población de Magallanes no advirtió mejora sensible alguna durante los años que siguieron y, por el contrario, se comprobó un deterioro del servicio que acabó por desacreditarse y desaparecer pasado $1960^{92}$.

Pero para la zona norte comprendida entre Puerto Montt y Puerto Aysén la operación de la flota regional estatal fue no sólo bien realizada como servicio público de comunicaciones, sin embargo de su costo que lo haría progresivamente antieconómico, sino que además fue un eficaz medio de apoyo y de fomento al poblamiento y al desarrollo regional, en particular para los distritos de más reciente incorporación a dicho proceso, del mismo modo como fue beneficioso para el mejor desarrollo del comercio y para la salida de la producción económica del extenso ámbito geográfico así atendido.

El adelanto generalizado podía medirse entonces en la población de la zona que triplicaba en 1960 a la registrada en 1907. Magallanes en el mismo lapso había cuadruplicado el número de sus habitantes e incrementado sustancialmente su riqueza ahora no sólo la tradicional agropecuaria (lana, carne), sino también mineral (hidrocarburos).

tomado de El Magallanes del 24 diciembre de 1938.

92 El servicio operó bajo la tuición de Ferronave (Departamento Marítimo de FF.EE. y creado el 27 de octubre de 1939), que a contar de 1953 se transformó en la Empresa Marítima del Estado.
La colonización aisenina había adelantado notoriamente para entonces y proseguiría en los años por venir, extendiéndose prácticamente sólo por el áspero territorio continental en una progresión expansiva este/oeste y también norte/sur señalada por el ímpetu pionero. No sucedió igual en los sectores litorales del mar interior que demostraron ser inaptos para la colonización de los que el mejor ejemplo de fracaso fue el intento realizado en 1953 en el fiordo Quitralco. La presencia pobladora únicamente se afirmó sobre sectores bien acotados como Puerto Cisnes y Puyuhuapi en Aysén, Chaitén en Chiloé continental y Cochamó en la sección septentrional patagónica bajo jurisdicción de Llanquihue. Más al meridión, al sur de Taitao (y de Ofqui), en la zona marítima del Baker algunos contados pioneros procuraron establecerse pasado 1950 lo que consiguieron a costa de penosos esfuerzos y contando con el vital aunque sólo ocasional auxilio de la Armada Nacional desde su base en Punta Arenas.

Para entonces el curso del proceso -como lo había hecho históricamente desde un principio-exigía la construcción de vías camineras de intercomunicación entre los distritos poblados y de salida hacia los puertos para superar las tremendas limitaciones que tal carencia (y la no siempre fácil ni cómoda dependencia sustitutiva de Argentina) imponían al bienestar de sus habitantes y al progreso general.De ese modo en una constante que no conoció pausa, aun en los momentos de mayor escasez presupuestaria fiscal -por años casi una norma-se fue planteando paciente y ejecutando laboriosamente un sistema vial interior en Aysén, orientado en general por los valles fluviales en sentido este/oeste, de sencillo a complejo, en el que un trazado unificador longitu-

93 Incluye sólo los departamentos de Llanquihue, Calbuco y Maullín; y Provincia de Chiloé (Deptos. Ancud, Castro, Quincheo y Palena). 
dinal parecía cosa imposible por las características fisiográficas archiconocidas. Pero soñado inicialmente, ejecutado desde principio de los años de 1960 y planificado formalmente a contar de 1968, al cabo de tres décadas de trabajo sostenido, de recursos provistos con visión de Estado, cobró forma la Carretera Austral como una vía unificadora de comunicaciones y como eficaz vertebradora del desarrollo generalizado ${ }^{94}$.

Esta admirable obra vial, orgullo de los chilenos, brindó en su magnífica realidad operativa una perspectiva distinta, hasta novedosa, al desarrollo de las regiones patagónicas norte y central de Chile, al pasar a ser "el eje" conductor para los efectos de la integración intrarregional y con Chile al norte del Reloncaví, en reemplazo del histórico "camino del mar interior" (Corcovado-canales patagónicos del norte). En ese fenómeno sustitutivo de facto, forzando por así decirlo el imperativo de la geografía, la península de Taitao con su istmo quedaron al margen, sirviendo solamente como ámbito de separación de dos espacios ecosistémicos distintos.

El proceso dinámico de desarrollo (infraestructural, económico y social) de que se trata influyó de modo determinante en la evolución de la macrorregión centro-norte de la Patagonia chilena (Aysén-Chiloé continental y comunas de Cochamó y Huailahué) haciendo crecer su población y sus producciones diversificadas, generando una intensa relación de intercambio e integración física y social, tanto hacia su interior cuanto con Chile al norte del Reloncaví. Además del determinante rol de las comunicaciones marítimas desde los 40 en adelante y su progresiva modernización, hicieron lo suyo la navegación aérea a partir de la mitad del siglo y los sistemas modernos de transporte mixto terrestre-marítimo, (roll on-roll off) hacia 1980-90, sin olvidar por cierto las otras formas tecnológicas para las comunicaciones personales de progresiva incorporación y al fin de uso y difusión masivos. La población del amplio sector geográfico de que se trata superaba para los comienzos del siglo XXI (censo nacional de 2002) las 900.000 almas, dato de suyo significativo respecto de lo acontecido allí a lo largo del siglo XX.

En el distante sur, más allá del golfo de Penas

94 Para mayor información sobre el particular sugerimos ver nuestro libro De la Trapananda al Áysen (Ediciones Pehuén, Santiago, 2004 pp. 400 y siguientes). y del Archipiélago Patagónico, Magallanes había afirmado su propio crecimiento y adelanto con características de autonomía. Sus sistemas internos de comunicaciones marítimas, viales y aéreas, habían contribuido eficazmente a su evolución en progreso. Sus vinculaciones con el mundo exterior (Argentina, otros países del Atlántico americano y Europa) se habían recompuesto tras la crisis de la segunda postguerra mundial y acomodado a las circunstancia del tiempo y de la modernidad globalizadora. A contar de la segunda mitad de los años de 1960 se incorporó como novedad el uso de los caminos argentinos para el transporte motorizado de carga y de pasajeros entre Magallanes y Llanquihue (acceso por el paso fronteriza de Puyehue) y viceversa, como una variable comunicacional cada vez más importante en tanto que sustitutiva del perimido transporte marítimo, que sin embargo de ello se mantendría aunque adecuándose a las circunstancias. Cuando los momentos de tensión en 1978 entre Chile y Argentina a propósito de la cuestión del Beagle significaron trabas y dificultades para el transporte terrestre por suelo argentino, surgió como nueva alternativa el sistema mixto terrestre-marítimo roll on-roll off, estableciéndose en consecuencia y de manera definitiva un servicio regular del género entre Puerto Montt y Puerto Natales (con eventual escala en Puerto Chacabuco) que pasó a complementar y a hacer más eficiente la vinculación entre Magallanes y Llanquihue, en tanto que puerta de entrada y de salida desde Chile metropolitano. Complementario porque en verdad el transporte terrestre por suelo argentino se normalizó un vez superadas sus dificultades y se ha manteniendo activo hasta el presente.

El adelanto en la materia comunicaciones personales fue también notable en esta región pues en sucesivas etapas-hitos de progreso se pasó de la telegrafía y la telefonía alámbricas, a la radiotelegrafía y la radiotelefonía, para llegar con el quinto final del siglo a las comunicaciones por la vía satelital y a la fibra óptica.

Pero sin duda alguna el medio de transporte que de manera más eficaz contribuyó a superar la arraigada noción del aislamiento magallánico respecto del resto de Chile fue la navegación aérea. Luego del fracasado intento pionero de 1937 por parte de la Fuerza Aérea, el sistema se estableció y consolidó progresivamente a contar de 1946 operado por la empresa estatal Línea Aérea Nacional. 
Más allá de su indudable beneficiosa consecuencia, significó también en los hechos que Magallanes "se saltara" la inmensidad geográfica patagónica chilena para acceder, con escala en Puerto Montt, al Chile metropolitano. Ello haría que, a la corta, la noción de vecindad con Aysén y Chiloé, si es que de ella se tuvo realmente conciencia alguna vez en su población, se perdiera virtualmente.

En este contexto comprensivo de la evolución patagónica chilena a lo largo del siglo XX la integración de sus componentes geográficos en plan de un mejor y más armónico desarrollo, era, como lo es, una tarea pendiente.

\section{HACIA UNA MAYOR INTEGRACIÓN INTRAPATAGONICA CHILENA.LA SUPERACIÓN DEL ÚLTIMO DESAFÍO GEOGRÁFICO}

La iniciativa de abrir el istmo de Ofqui y el consiguiente proyecto de un canal se sustentó originalmente en cinco aspectos: 1) Conveniencia estratégica naval, al brindar a la Armada Nacional la posibilidad de una ruta interior segura para sus unidades livianas y una base de operaciones en la bahía de San Quintín; 2) Fomento del comercio marítimo intrarregional (Chiloé a Magallanes) como consecuencia del mayor movimiento de naves mercantes; 3) Extensión de la colonización con la incorporación del área de la península de Taitao y zonas al sur de la misma; 4) Mayor y más eficiente vinculación entre Chile metropolitano y Magallanes (y viceversa) como consecuencia del uso creciente de una ruta marítima interior complementaria de la interior-exterior entonces vigente, con beneficio para las comunicaciones, transporte de personas $y$ cargas; y 5) La integración intrarregional.

Lo acontecido con el proyecto y sus avatares y los cambios de circunstancias y situaciones a lo largo del siglo XX fueron ocasionando sucesivas mutaciones al panorama originalmente planteado. En efecto el primer punto perdió vigencia con la solución paulatina que tuvieron las cuestiones de límites pendientes con Argentina; el segundo únicamente se vio cumplido en lo referido al tráfico comercial entre Llanquihue, Chiloé y Aysén; el punto tercero resultó ser una utopía pues la colonización se realizó por el interior continental y los terrenos o sectores litorales aptos para el caso comenzaron a incorporarse recién hacia la cuarta década o mitad del siglo (sectores de Cisnes, Puyuhuapi y Palena); el cuarto punto se cumplía a la larga por otras alternativas (principalmente por la comunicación aérea); y sólo mantendrá su vigencia el punto quinto como necesidad geopolítica en lo referido a la integración entre Aysén y Magallanes.

Tocante a este punto, como en otros aspectos la construcción y operación de la Carretera Austral, en el caso de su tramo terminal entre Puerto Bertrand y Puerto Yungay-Caleta Tortel, brindó una nueva y potente oportunidad para integrar más y mejor a Aysén y Magallanes. En efecto, con un mapa a la vista la aproximación conseguida era asombrosa y debía, como debe apreciarse en grados geográficos de latitud pues en su extensión meridional esa vía ha alcanzado (y sobrepasado) los $47^{\circ} 30^{-} \mathrm{S}$ lo que significa en la práctica haber llegado por el lado norte al máximo límite posible de desarrollo longitudinal de la carretera en vista del colosal obstáculo que representa el Campo de Hielo Patagónico Sur.

Pero si tal ocurre allí, distinto es por el meridión del mismo, esto es, por la sección noroccidental de Magallanes pues aquí se ofrece la posibilidad de repetir siquiera en parte y en sentido inverso el prodigioso esfuerzo constructivo vial troncal realizado en las zonas central y norte de la Patagonia chilena, en la forma de un camino de penetración con rumbo general oeste-noroeste-norte, uniendo puerto Laforest (sector litoral de la península Antonio Varas que enfrenta, canal Señoret de por medio, a Puerto Natales) con el fiordo Peel en la vertiente occidental de los Andes (Lat. 50 50`S).

La primera iniciativa en este sentido provino del ingeniero Antonio Horvath quien en 1985 planteó en Aysén la posibilidad de unir a esa región con la de Magallanes a través de una nueva ruta mixta terrestre-marítima, propuesta seguida por una expedición exploratoria realizada en el verano de $1986^{95}$. Su satisfactorio desarrollo y el conocimiento obtenido en el terreno permitió a Horvath proponer formalmente la "Ruta de Integración entre Aysén y Magallanes por territorio chileno), que partiendo desde Puerto Yungay llega a Puerto Natales, combinando sectores de posible construcción terrestre

95 Mayor información sobre el punto puede encontrarse en nuestra obra Archipiélago Patagónico, la última frontera (Ediciones de la Universidad de Magallanes, Punta Arenas 2004), p. 270. 


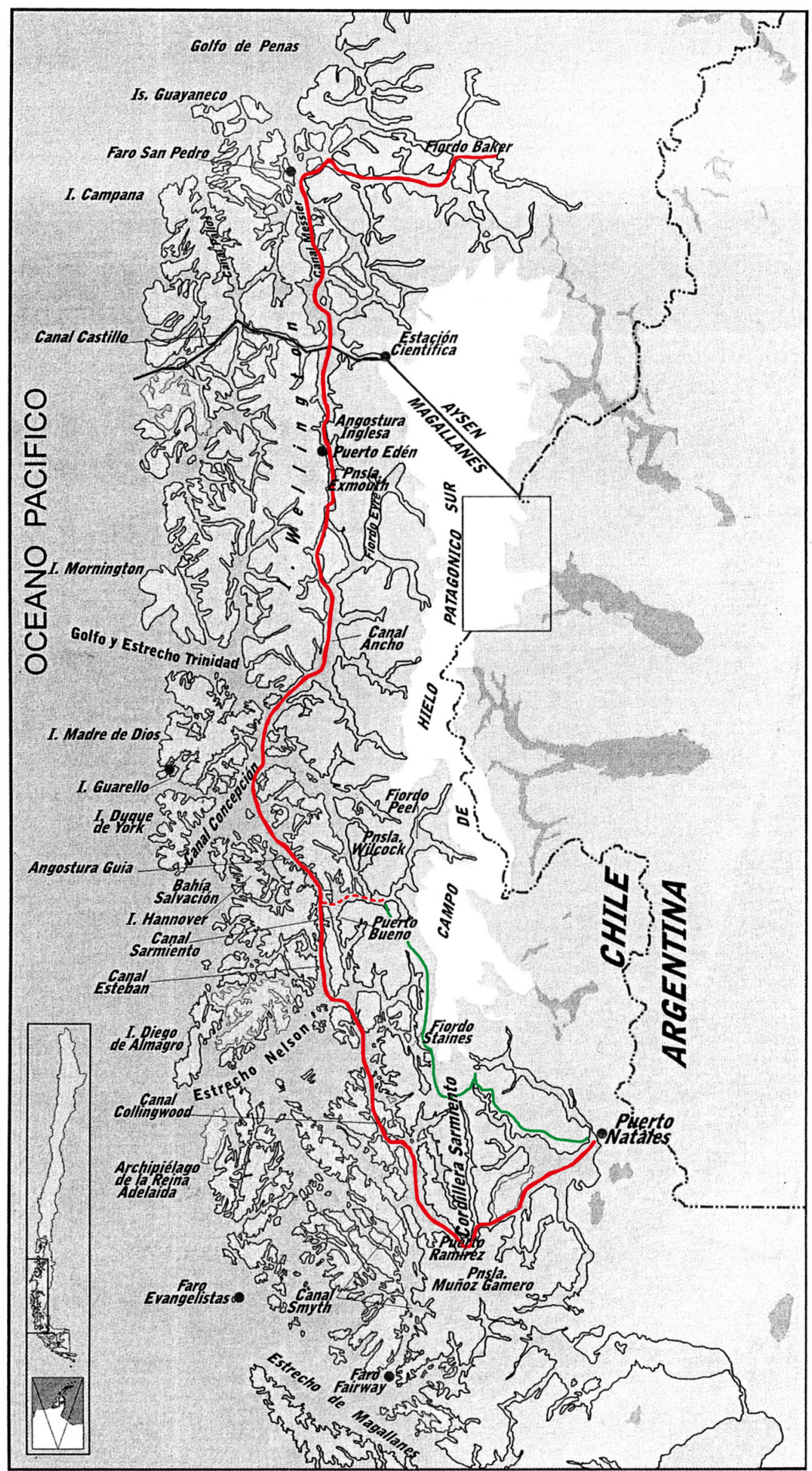

Fig. 4 Archipiélago Patagónico. La línea roja indica el trayecto marítimo entre Puerto Yungay-Caleta Tortel y Puerto Natales, la línea verde y la roja segmentada indican la variante Puerto Natales-Fiordo Peel. 
(256 kms.) con zonas de navegación obligada (434 kms.), totalizándose así 690 kilómetros de longitud para la ruta planteada ${ }^{96}$.

La propuesta de Horvath despertó inmediato interés en Magallanes, en particular en el seno del Consejo Regional del Colegio de Ingenieros, donde se la analizó con detenimiento, se valoró su factibilidad y se acordó recomendar a las autoridades regionales el estudio de la iniciativa con miras a construir una ruta o senda de penetración a través de la península Antonio Varas (territorio continental de Patagonia) Para acceder al fiordo Staines en la zona occidental de la cordillera de los Andes, ruta pensada como parte integrante del sistema de conexión terrestremarítimo ideado por el ingeniero Horvath.

Con este respaldo y otros que se fueron agregando en 1992 el Ministerio de Planificación recomendó la realización de estudios preliminares para desarrollar el proyecto vial en forma de ruta de penetración. Al fin, demoras e interrupciones burocráticas de por medio, la Dirección de Vialidad elaboró un proyecto, lo incorporó al programa regional de obras públicas y se inició en 1995 la construcción del camino a cargo del Cuerpo Militar del Trabajo (CMT), de bien acreditada fama y competencia con la experiencia ganada en las obras de la Carretera Austral en Chiloé Continental y en Aysén. La obra, de alto costo, fue avanzando lentamente hasta alcanzar en marzo de 2003 la bahía Talcahuano, a 42 kilómetro del punto de partida (puerto Laforest). Aquí la obra se detendría hasta el presente tanto porque localmente surgió una alternativa de continuidad de la ruta por otro sector situado más al norte que aunque en definitiva se desestimó impuso la suspensión momentánea de los trabajos, cuanto porque en esa circunstancia el Ministerio de Obras Públicas decidió a partir de 2010 priorizar otro camino de penetración en construcción en la isla grande de Tierra del Fuego (Vicuña a Yendegaia) y pidió al CMT que trasladara sus equipos allí, donde continúan hasta el presente ocupados en el avance de la ruta cuya finalización está prevista para 2020.

Mientras así sucedía, hacia fines de 2009 el Ministro de Obras Públicas Sergio Bitar acompañado por Juan Miranda, Secretario Regional de Obras Públicas de Magallanes, tuvo la oportunidad de realizar un vuelo de exploración en helicóptero sobre el sector litoral comprendido entre el fondo 96 Id. pp. 272 y 273. del fiordo Staines y la entrada del fiordo Peel, que permitió comprobar la posibilidad de extender la ruta desde el punto de término originalmente previsto en la costa de Staines hasta la del Peel. En este sector este formidable accidente geográfico con su curso oeste-este interrumpe definitivamente la continuidad de una ruta terrestre hacia el norte. Este descubrimiento hace más atractiva y conveniente la prosecución de los trabajos de construcción del camino de penetración de que se trata ${ }^{97}$. Pero más allá de la determinación que habrá de adoptarse más temprano que tarde, está a la vista y disponible hoy la posibilidad de la unión marítima entre Puerto Yungay y Puerto Natales mediante el uso de naves transbordadoras (sistema roll on roll off).

En efecto, planteado formalmente como propuesta de acción al concluir el gobierno de la Presidenta Michelle Bachelet (La Prensa Austral, 25 de febrero de 2010), su materialización se vio demorada más por razones de inepcia e insensibilidad burocráticas y sólo recobró vigencia a contar de mayo de 2013 con la petición conjunta de las Municipalidades de Caleta Tortel y de Cochrane en orden a establecer un servicio de transporte (transbordador) entre Caleta Tortel-Puerto Yungay y Puerto Natales con una conexión semanal ${ }^{98}$. Este planteamiento fue hecho por las correspondientes autoridades ante la comisión de Zonas Extremas del Senado de la República. El interés que despertó tal petición en sectores sociales condujo al Ministerio de Transportes a disponer la entrega de los recursos económicos necesarios para concretar el "Proyecto de conectividad Austral Chile por Chile", según anuncio hecho por el Senador de Magallanes Carlos Bianchi $^{99}$. Es de esperar que la iniciativa no acabe en mera promesa y que pueda concretarse en cuanto sea posible, esto es, cuando haya voluntad en el Poder Ejecutivo de llevar a buen e inmediato término una medida de indiscutible necesidad reclamada, ahora sí, de consuno por las comunidades del sur de Aysén y del norte de Magallanes. (fig. 4)

Cabe un somero análisis respecto de las ventajas y beneficios que pueden esperarse de un

97 Encontrándose en prensa este artículo nos hemos enterado de la instalación del CMT en el sector de que se trata y para proseguir con los trabajos del camino de penetración con un nuevo contrato que permitirá construir alrededor de 10 km entre el río Baguales ( $\mathrm{km} \mathrm{40,200)} \mathrm{y} \mathrm{el} \mathrm{fiordo} \mathrm{Worsley.}$

98 La Prensa Austral, Punta Arenas 8 de mayo del 2013

99 Id., ediciones del 16 de mayo y 12 de junio 2013. 
proyecto de conectividad como es el de que se trata.

Es bueno para Magallanes por que se requiere imperiosamente incorporar de modo efectivo y definitivo en la noción cultural de sus habitantes la pertenencia de un vasto y semi ignoto territorio en la vertiente occidental como es el Archipiélago Patagónico ${ }^{100}$ y la capacidad productiva económica del mismo con su potencialidad minera (Madre de Dios), pesquera (canales interiores) y turísticas (todo el distrito). Es bueno asimismo para la relación aisenino-magallánica, hoy virtualmente inexistente, en especial en lo tocante al conocimiento de un territorio que en parte conforma una herencia histórica común. Es, por fin, bueno per se que el tráfico de pasajeros y carga entre Magallanes y el resto del país se haga complementariamente por territorio nacional ("conocer el país es un deber").

En tanto así se haga en el próximo futuro por la vía marítima propuesta, adelantará la construcción del camino de penetración hacia su meta en la costa del fiordo Peel, paraje de profunda reminiscencias históricas ${ }^{101}$. De esa manera, algún día la Ruta de Integración Austral una vez soñada devendrá una feliz realidad con el proyecto mixto terrestre marítimo que habrá de reducir la duración del viaje a no más de 24 horas de navegación efectiva (248 millas). Al revés del fallido proyecto de Ofqui este no será una quimera.

\section{AGRADECIMIENTOS}

El autor deja constancia de su reconocimiento para con los señores Victor Sierpe y Rodrigo Muñoz por la colaboración prestada en la recuperación fotográfica de la información de prensa y al segundo, además, por la entrega de datos de interés para el trabajo.

100 Debe tenerse presente que desde el establecimiento de la colonización Magallanes ha funcionado de hecho como entidad social y económica ocupando sólo el distrito de la vertiente oriental de la cadena andina, esto es, menos del $50 \%$ de su extenso territorio jurisdiccional americano.

101 Alli en el sector se ubica el tradicional fondeadero de Puerto Bueno, afamado de siglos por su calidad, punto que con sus sectores aledaños fue una de las zonas nucleares del ámbito ancestral de la etnia Kawéskar. Uno de los brazos del Peel asimismo o franquea el acceso al corazón del Campo de Hielo Patagónico Sur por su término austral y como tal ha sido y es meta de exploradores científicos y de montañeros.

\section{LITERATURA CITADA}

a) Principal

Arancibia, Clavel, P. \& A. Soto (2005). 75 años Navegando por los mares. Historia de la Compañía Chilena de Navegación Interoceánica S.A. 1930-2005. Santiago: CCNI.

Butland, Gilbert J. (1957). The Human Geography of Southern Chile.London-Liverpool :The Institute of British Geographers (Publication $\left.\mathrm{N}^{\circ} 14\right)$.

Cassassa, G. \& C. Marangunic(1987). Historia de la Exploración del Hielo Patagónico Norte. En Glaciological Studies in Patagonia 1985-1986(pp. 163-175). Santiago: Data Center for Glacier Research, Japanese Society of Snow and Ice.

Castagneto, P. \& D. Lazcano (2011). Buques de Guerra chilenos 1850-1950. Un siglo en imágenes. Santiago: RIL Editores.

Cerón, M.; A. Perez, A. Heinemann, E. Cibotti, R Durandeau, A. Laurido, T. Korn \& A. Salles(1944). Magallanes en su primer centenario. Punta Arenas:Instituto Comercial de Punta Arenas.

Chubretovich Alvarez, C. (2012). Recuerdos de mi bitácora. Viña del Mar: Edición del autor.

Corporación de Fomento de la Producción (1962). Geografía Económica de Chile. Santiago: CORFO (Tomo IV).

Ferrer Fouga, H. (1988). Las expediciones hidrográficas y su importancia para las comunicaciones marítimas. En:Chiloé y su influjo en la XI Región. II Jornadas Territoriales(pp.83-144).Santiago : Instituto de Investigaciones del Patrimonio Territorial de Chile, Universidad de Santiago (Colección Terra Nostra N 12).

Chisolfo Olmedo, F. (1988). Sistema de comunicaciones. En: Chiloé y su influjo en la XI Región. II Jornadas Territoriales(pp.1155-139).Santiago:Instituto de Investigación del Patrimonio Territorial de Chile, Universidad de Santiago (Colección Terra Nostra N ${ }^{\circ} 12$ ).

Garrido, E., P. Castagneto, V. Mesina \& E. Rivera (2006). Historia de la Marina Mercante Chilena 1541-2006. Valparaíso:Asociación Nacional de Armadores.

Grenier, P. (2003). Des tyrannosauresdans le paradis. La ruée des transnationales sur la Patagonia Chilienne. Nantes:L'Atalante.

Grosse, A. (1986). Visión histórica y colonización de la Patagonia occidental. Santiago:Ministerio de Obras Públicas.

Instituto Hidrográfico de la Armada de Chile (1974). Atlas Hidrográfico de Chile. Valparaíso: Instituto Hidrográfico de la Armada de Chile.

Jimenez Michaelis, A. (2007). La apertura del Istmo de Ofqui. Una oportunidad para la Patagonia. http:// 
calidaddevida-alejandro.blogspot.com/2007/01/laapertura-del-istmo-de-ofqui.html.

Keller, C. (1949). La Región del Hielo Continental de Aysén. Santiago: Editorial Sociedad Amigos del Libro.

Mancilla Ruiz, A. (1946). Chile Austral (Aysén). Santiago: Instituto Geográfico Militar.

Martinic, M. (1977). Historia del Estrecho de Magallanes. Santiago: Editorial Andres Bello.

Martinic, M. (2004). Archipiélago Patagónico, la última frontera.

Punta Arenas:Ediciones de la Universidad de Magallanes.

Martinic, M. (2005. De la Trapananda al Áysen. Santiago: Pehuén.

Martinic, M. (2006 [1992]) Historia de la Región Magallánica. Punta Arenas:Ediciones de la Universidad de Magallanes.

Monje Mira, J. (1944). El istmo de Ofqui. Revista Chilena de Historia y Geografía,105, 5-44.

Monje Mira, J. (1945). El istmo de Ofqui (continuación). Revista Chilena de Historia y Geografía,106, 62-102.

Monje Mira, J. (1946). El istmo de Ofqui (continuación). Revista Chilena de Historia y Geografía107, 296-338.

Servicio Hidrográfico y Oceanográfico de la Armada de Chile (2011). Atlas Hidrográfico Histórico. Levantamientos realizados por la Marina de Chile entre los años de 1834 y 1899. Valparaíso: Armada de Chile.

Simpson, E. (2011). Viajes de exploración por los archipiélagos australes.Temuco: Ofqui editores.

Steffen, H.(1909). Viajes de exploración y estudio en la Patagonia occidental. Santiago: Imprenta Cervantes.

Steffen, H.(2009 [1944]) Patagonia Occidental. Las Cordilleras Patagónicas y sus Regiones Circundantes.Santiago: Editorial La Silla.

Subercaseaux, B. (1973 [1940]). Chile, o una loca geografía. Santiago: Editorial Universitaria.

Urbina, M. (2010). La navegación por los canales australes en la Patagonia occidental insular en los siglos coloniales: La ruta del Istmo de Ofqui. Magallania38(2), 41-67.

De Vidts, E. (1910). Estudios del Proyecto de apertura del Canal de Ofqui. Valparaíso.

De Vidts, E. (1921). Ventajas de la apertura del istmo de Ofqui. Revista Chilena de Historia y Geografía42, 139-143. b) Complementaria

Aguirre Cerda, P. (1935). Magallanes y el Istmo de Ofqui. La Nación, edición 2 de abril, Santiago.

Alarcón Fabres, D. (2006). Apertura del istmo de Ofqui: ¿Un regalo para el Bicentenario? El Magallanes, edición del 4 de junio. Punta Arenas.

BalmelliUrzua, H. (1980). Actualidad del istmo de Ofqui,Trapananda $N^{\circ} 3$, febrero de 1979. Coyhaique.

Diario El Magallanes Ediciones completa años 1931 a 1939 y 1943 a 1945; Ediciones extraordinarias del 17 de noviembre de 1939 y del 15 de febrero de 1944; edición del 17 de febrero de 1944. Punta Arenas.

Empresa de FF.CC. del Estado (1941). Revista En Viaje. Números de julio y octubre. Santiago.

Erazo, L. \& S. Sánchez (1982). Localización de posibles alternativas de caminos en la zona del istmo de Ofqui. Trapananda №4 abril de 1981 -abril 1982: 73-76. Coyhaique.

S/Autor (1937). Apertura del istmo de Ofqui (información) Revista Menéndez Behety, № 166 (octubre). Punta Arenas.

S/Autor (1937). Apertura del istmo de Ofqui Editorial Revista Menéndez Behety, № 166 (octubre). Punta Arenas.

S/Autor (1983). Abrir el istmo de Ofqui. Revista del Domingo (Diario El Mercurio edición 4 de septiembre de 1983). Santiago.

De Vidts, E. (1980). Estudio del Proyecto Ofqui. Trapananda $\mathrm{N}^{\circ}$ 3, febrero de 1970 marzo de 1980: 92-99. Coyhaique.

c) Fuentes Digitales

S/Autor. En Datos Anecdóticos e Históricos de Chile. Blog: http://datoshistoricosdechile.blogspot.com/2012/07/ que-fue-del-canal-de-ofqui.html

S/Autor La Puerta de atrás al Sur. El proyecto de construcción del canal Istmo de Ofqui. En: Ferrocarriles en el Cono Sur, http://www.ferrocarrilesenelconosur. co.uk/13Sjisthmusofofa.html. 